\title{
Behaviour, booster vaccines and waning vaccine protection: modelling the medium-term dynamics of SARS-CoV-2 transmission in England
}

Rosanna C. Barnard ${ }^{* 1,2}$, Nicholas G. Davies ${ }^{1,2}$, Centre for Mathematical Modelling of Infectious Diseases COVID-19 working group ${ }^{\dagger 1}$, Mark Jit ${ }^{1,2} \&$ W. John Edmunds ${ }^{1,2}$

${ }^{1}$ Centre for Mathematical Modelling of Infectious Diseases, London School of Hygiene \& Tropical Medicine, Keppel Street, London, WC1E 7HT, UK

2 Department of Infectious Disease Epidemiology, London School of Hygiene \& Tropical Medicine, Keppel Street, London, WC1E 7HT, UK

* Correspondence: rosanna.barnard@Ishtm.ac.uk

† See end material for working group authors 
medRxiv preprint doi: https://doi.org/10.1101/2021.11.22.21266584; this version posted November $24,2021$. The copyright holder for this
preprint (which was not certified by peer review) is the author/funder, who has granted medRxiv a license to display the preprint in It is made available under a CC-BY-NC-ND 4.0 International license.

\section{Abstract}

England has experienced a heavy burden of COVID-19, with high infection levels observed throughout the summer months of 2021. Alongside the emergence of evidence suggesting that COVID-19 vaccine protection wanes over time, booster vaccinations began for individuals aged 50 and above in September 2021. Using a model fitted to 18 months of epidemiological data, we project potential dynamics of SARS-CoV-2 transmission in England to September 2022. We consider key uncertainties including behavioural change, waning vaccine protection, strategies for vaccination, and the reintroduction of public health and social measures. We project the current wave of transmission will peak in Autumn 2021, with low levels of transmission in early 2022. The extent to which SARS-CoV-2 transmission resurges in 2022 depends largely on assumptions around waning vaccine protection and booster vaccinations. Widespread booster vaccinations or the reimposition of mild public health and social measures such as work-from-home policies could largely mitigate the wave of COVID-19 transmission projected to occur in England in Spring/Summer 2022. 
medRxiv preprint doi: https://doi.org/10.1101/2021.11.22.21266584; this version posted November 24 , 2021. The copyright holder for this preprint (which was not certified by peer review) is the author/funder, who has granted medRxiv a license to display the preprint in It is made available under a CC-BY-NC-ND 4.0 International license .

\section{Main}

Eighteen months into the COVID-19 pandemic, 250 million confirmed cases and 5 million deaths have been attributed to severe acute respiratory syndrome coronavirus 2 (SARS-CoV-2) worldwide ${ }^{1}$. In England as of 17th November 2021, cumulative confirmed COVID-19 cases exceed 8 million, with more than 500,000 hospitalisations and 120,000 deaths within 28 days of a positive test being recorded, respectively ${ }^{2}$. Different variants of SARS-CoV-2 have emerged, with four (Alpha, Beta, Gamma and Delta) currently designated as variants of concern (VOC) associated with either increased transmissibility, severity, or changes in immunity by the World Health Organisation ${ }^{3}$. England saw the emergence and takeover of the Alpha B.1.1.7 variant in late 2020, which was subsequently overtaken by the Delta B.1.617.2 variant in Spring 2021. Various public health and social measures (PHSMs) have been implemented to suppress COVID-19 transmission in England, including national lockdowns, staged relaxations of lockdowns and tiered regional restrictions ${ }^{4}$, but all legal restrictions were completely lifted on 19th July 2021.

Safe and effective COVID-19 vaccines have been developed at unprecedented speed, with four currently approved for use by the UK's Medicines and Healthcare products Regulatory Agency (MHRA). The COVID-19 vaccine rollout in England began on the 8th of December 2020 and to date more than 42 million people have received at least their first COVID-19 vaccine dose ${ }^{2}$. The initial rollout of vaccines followed guidance issued by the UK's Joint Committee on Vaccination and Immunisation $(\mathrm{JCVI})^{5}$, with vaccine supply being targeted to health and social care workers and those in the highest risk categories first. Vaccines were then offered to sequentially younger age groups of adults (18 years and above). In August 2021, children aged 16 and 17 years old and clinically vulnerable children aged 12-15 were offered COVID-19 vaccines ${ }^{6}$. In September 2021, healthy 12-15-year-olds in England were offered their first COVID-19 vaccination, but to date, no such recommendation has been made for the second dose follow up ${ }^{7}$.

A COVID-19 booster vaccination programme began on 24th September 2021, initially targeting the same priority groups that were first vaccinated. A full dose of the Pfizer/BioNTech or a half dose of the Moderna vaccine are recommended as a booster dose, regardless of what vaccine was received previously, to those at least 6 months after their primary course of vaccination. On 15th November 2021, the JCVI issued advice recommending that the widespread COVID-19 booster vaccination programme be extended to individuals aged 40-49 years $^{8}$. In addition to a widespread booster vaccination programme, the JCVI have recommended that severely immunocompromised individuals over 12 years of age should be offered a third COVID-19 vaccination dose as part of their primary COVID-19 vaccination schedule ${ }^{9}$. With rising COVID-19 incidence and concerns about hospital bed pressures over the coming months, stakeholders including the British Medical Association have also called for the introduction of PHSMs in place in several other European countries, including face covering mandates, vaccine certification and encouragement to work from home where possible ${ }^{10}$. In addition to this, evidence continues to emerge about waning vaccine protection over time ${ }^{11,12}$. 
medRxiv preprint doi: https://doi.org/10.1101/2021.11.22.21266584; this version posted November 24 , 2021. The copyright holder for this preprint (which was not certified by peer review) is the author/funder, who has granted medRxiv a license to display the preprint in

It is made available under a CC-BY-NC-ND 4.0 International license .

Using an age-structured deterministic compartmental model of SARS-CoV-2 community transmission, we project the consequences of behavioural changes, waning vaccine protection and of different vaccination and PHSMs on COVID-19 cases, hospitalisations and deaths into 2022. We fit the model to region-specific data on COVID-19 deaths, hospitalisations, and hospital bed occupancy, as well as PCR prevalence, seroprevalence, and the emergence of the Alpha B.1.1.7 and Delta B.1.617.2 VOCs, as well as integrating data on the number of vaccinations delivered at the level of NHS England regions and by age group. We consider the effects of fully vaccinating different age groups of adolescents and children in the future, different levels of uptake for these age groups, as well as the consequences of implementing mass COVID-19 booster vaccination campaigns in different age ranges in the population, seasonality, and the implementation of PHSMs to suppress projected rises in transmission. Considering different assumptions on vaccine rollout going forwards, we explore the projected dynamics of SARS-CoV-2 transmission over the winter months and until September 2022.

\section{Results}

Our compartmental model fits the observed dynamics of SARS-CoV-2 community transmission during the first, second and third waves of the COVID-19 epidemic in England between mid-February 2020 and October 2021 (Figs. 1 and S1), reproducing NHS England region-specific observed deaths, hospitalisations, hospital and ICU bed occupancy, PCR prevalence, and seropositivity. The model also captures the emergence and spread of the Alpha B.1.1.7 and Delta B.1.617.2 variants of concern in late 2020 and early 2021, fitting to the prevalence of S gene target failure (Fig. S2) and to the proportion of Delta sequenced cases (Fig. S3). Model estimates for increased transmissibility of Alpha relative to previously circulating SARS-CoV-2 variants and of Delta relative to Alpha are given in Table S1.

To capture historic behavioural changes, the model uses Google Community Mobility indices over time to derive contact rates for each NHS England region modelled, based upon a measured relationship between Google Mobility indices and age-specific contact rates as measured by the CoMix study, and in combination with school attendance data and assumptions about school schedules (Fig. 2). The model also fits a time-varying "transmission adjustment" component for each NHS England region in order to capture additional variability in transmission that is not explained by the mobility data (see Methods). The fitted transmission adjustment can be seen in the middle row of Fig. 2; there are notable sharp peaks around Christmas 2020 and towards the end of Summer 2021, as well as a deep trough around the lockdown in early 2021. To project behavioural changes forwards from October 2021 to September 2022, we combine various assumptions on future mobility changes (Fig. 2) with simulated trajectories for future transmission adjustments based on the historic fitted transmission adjustment (full details are given in the Methods section).

We present the majority of results here by plotting the median and interquantile ranges of a number of simulated future trajectories of SARS-CoV-2 transmission in England, but it is important to note that individual epidemic trajectories can fall outside of the model's 
medRxiv preprint doi: https://doi.org/10.1101/2021.11.22.21266584; this version posted November 24 , 2021. The copyright holder for this preprint (which was not certified by peer review) is the author/funder, who has granted medRxiv a license to display the preprint in

It is made available under a CC-BY-NC-ND 4.0 International license .

projection intervals (Fig. 3A). Some individual epidemic trajectories are projected to result in rapid exponential rises in transmission with large peaks that may require PHSMs to be implemented in response. A comparison of the projected cumulative number of SARS-CoV-2 infections, hospital admissions and deaths between October 2021 and September 2022 across all the scenarios considered here is shown in Fig. 4, along with detailed results related to each type of uncertainty in the Supplementary material (Figs. S4-S9). Although this work investigates the consequences of behavioural change, booster vaccination policies and waning vaccine protection, it is important to note that PHSMs also have the ability to suppress projected rises in transmission (Figs. 3B, 4, S4). A complete list of scenarios considered and key assumptions for each scenario is given in the Supplementary material (Table S6).

A key uncertainty is future behaviour and assumptions about future levels of mobility greatly influence the projected dynamics of SARS-CoV-2 transmission into 2022 (Figs. 3C, 4, S4). We consider three scenarios for future mobility (no change, a 3-month and a 6-month return to pre-pandemic baseline levels, shown in Fig. 2) to capture this uncertainty. All behavioural change scenarios considered project a peak in SARS-CoV-2 transmission in late 2021 followed by a decline to very low levels of transmission in early 2022 (Fig. S4). This is due to depletion of susceptible individuals due to a high force of infection in England during Autumn 2021. The scenario assuming no change in mobility projects that transmission remains at low levels through most of 2022, with early increases being projected by September 2022 . The largest difference in projected outcomes lies between the no change and return to baseline scenarios (Figs. 3C, 4, S4). However, the timing and speed of the return to baseline levels of mobility is important; a 3-month return to baseline mobility results in transmission rising sooner in 2022 and remaining flatter through the projected time horizon, whereas a 6-month return to baseline mobility levels leads to a later rise in transmission but a higher peaking epidemic (Figs. 3C, S4). Over shorter timescales, a more gradual return to baseline mobility decreases the total number of infections, hospital admissions, and deaths, but over long timescales there is less of a difference between different rates of returning to baseline (Fig. $\mathbf{S 4}$ tables). Both of the return to baseline mobility scenarios result in very similar cumulative numbers of SARS-CoV-2 infections, hospital admissions and deaths by the end of September 2022 (Figs. 3C, 4, S4). These differences can be explained by interactions between waning, seasonality, and mobility rates.

Other influential factors considered here are future policies on COVID-19 booster vaccinations and the rate at which vaccine protection wanes over time (Figs. 3D, 3E). Assuming a medium rate at which vaccine protection wanes, rolling out COVID-19 booster vaccinations has the largest overall effect in suppressing transmission of SARS-CoV-2 of all the scenarios considered (Fig. 4). Targeting booster vaccinations to individuals aged 50 years and above is estimated to have prevented around 50,000 deaths by September 2022, when compared with a counterfactual scenario where booster vaccinations were not implemented (Fig. 3D, S5). Scenarios where booster vaccinations are offered to sequentially younger age groups provide additional benefits in suppressing COVID-19 transmission into 2022, but with larger effects in reducing SARS-CoV-2 infections compared to reducing hospital admissions and deaths (Figs. 3D, 4, S5). Administering booster vaccinations to $90 \%$ of all individuals who receive two COVID-19 vaccinations is projected to suppress 
medRxiv preprint doi: https://doi.org/10.1101/2021.11.22.21266584; this version posted November 24 , 2021. The copyright holder for this preprint (which was not certified by peer review) is the author/funder, who has granted medRxiv a license to display the preprint in

It is made available under a CC-BY-NC-ND 4.0 International license

transmission of SARS-CoV-2 to low levels throughout the time horizon considered (Fig. S5), with 2.5 million less SARS-CoV-2 infections projected by September 2022, compared with the scenario offering booster vaccinations to individuals aged 40 and above, which is closest in line with the latest $\mathrm{JCVI}$ guidance ${ }^{8}$.

The extent to which vaccine protection wanes over time is a key uncertainty and different assumptions result in dramatically different projected transmission dynamics until September 2022 (Figs. 3E, 4, S6). We consider three waning vaccine protection scenarios for individuals who do not receive a third booster vaccination after their second COVID-19 vaccination: low, medium and high waning (Table S3). All three of these scenarios assume that $90 \%$ of vaccinated individuals aged 50 and above receive a booster vaccination. Low waning vaccine protection delays and reduces the projected resurgence in transmission, with 12,500 deaths projected to occur between October 2021 and September 2022 (Fig. S6 Table). The most extreme waning scenario considered results in a significant wave of transmission during the summer of 2022 , with 30,300 deaths projected to occur within the same timescale, with the potential for more than 1000 hospitalisations and 200 deaths to occur per day in England at the peak of transmission (Fig. S6).

The majority of scenarios considered project rises in SARS-CoV-2 transmission to occur towards the spring and summer months of 2022, with more pessimistic assumptions related to behaviour change, booster vaccination policy and waning vaccine protection leading to more significant and/or earlier resurgences (Figs. S4-6). For the most extreme waning scenario, we consider the additional introduction of temporary public health and social measures between 1st April and 31st May 2022 (Fig. S7). Of the three PHSMs considered, a vaccine certification policy, modelled as leading to increased vaccine uptake in individuals aged 18-29, had the smallest impact on projected transmission to September 2022. Introducing a work-from-home policy, modelled by returning work-related mobility to the same levels that were recorded during the week beginning 15th of March 2021, had the strongest effect in suppressing transmission during the intervention period. A combination of vaccine certification, increased mask wearing and work-from-home policies is sufficient to bring the reproduction number below 1 for the duration of the intervention period and is projected to result in 6,500 fewer deaths between October 2021 and September 2022 than the equivalent scenario without the introduction of PHSMs (Fig. S7). However, the introduction of PHSMs is modelled as a temporary measure, and transmission is projected to resurge again following their removal, eventually increasing above the levels projected to occur without any PHSMs being introduced (Figs. 3B, S7).

Different assumptions related to the extent of seasonality also influence the projected dynamics of SARS-CoV-2 transmission to September 2022 (Figs. 4, S8). Scenarios assuming more extreme seasonal effects result in smaller cumulative burdens between October 2021 and September 2022 (Fig. 4). However, scenarios assuming the most extreme seasonal effects appear to be resurging in September 2022 and may result in significant waves of transmission during the winter months of 2022-2023, far beyond the time horizons considered in this study. This effect can be observed by comparing short-term and longer-term outcomes; scenarios with greater seasonal effects are projected to result in more infections, hospitalisations and deaths between October and December 2021 but in 
medRxiv preprint doi: https://doi.org/10.1101/2021.11.22.21266584; this version posted November 24, 2021. The copyright holder for this preprint (which was not certified by peer review) is the author/funder, who has granted medRxiv a license to display the preprint in It is made available under a CC-BY-NC-ND 4.0 International license .

less infections, hospitalisations and deaths between October 2021 and September 2022 (Fig. S8 Tables).

Finally, we consider a number of scenarios related to the vaccination of children aged 12 years and above and children aged 5 years and above (Figs. 4, S9). Of all the uncertainties considered here, using different assumptions related to the vaccination of children had the smallest overall effect in projected SARS-CoV-2 transmission until September 2022 (Fig. 4). Between October and December 2021, different vaccination policies resulted in minor differences in the projected number of hospital admissions only (Fig. S9 Table). Between October 2021 and September 2022, different vaccination policies were projected to result in small differences across infections, hospital admissions and deaths (Fig. S9 Table). Scenarios assuming both higher uptake of COVID-19 vaccinations in children aged 12 and above and aged 5 and above or vaccinating wider age ranges of children are projected to result in marginal reductions in infections, hospital admissions and deaths between October 2021 and September 2022 (Fig. S9 Table), but not to significantly alter projected transmission dynamics (Fig. S9). This is due to high levels of infection in the model in these age groups during the autumn of 2021 (Fig. S10). 
medRxiv preprint doi: https://doi.org/10.1101/2021.11.22.21266584; this version posted November 24, 2021. The copyright holder for this preprint (which was not certified by peer review) is the author/funder, who has granted medRxiv a license to display the preprint in It is made available under a CC-BY-NC-ND 4.0 International license.
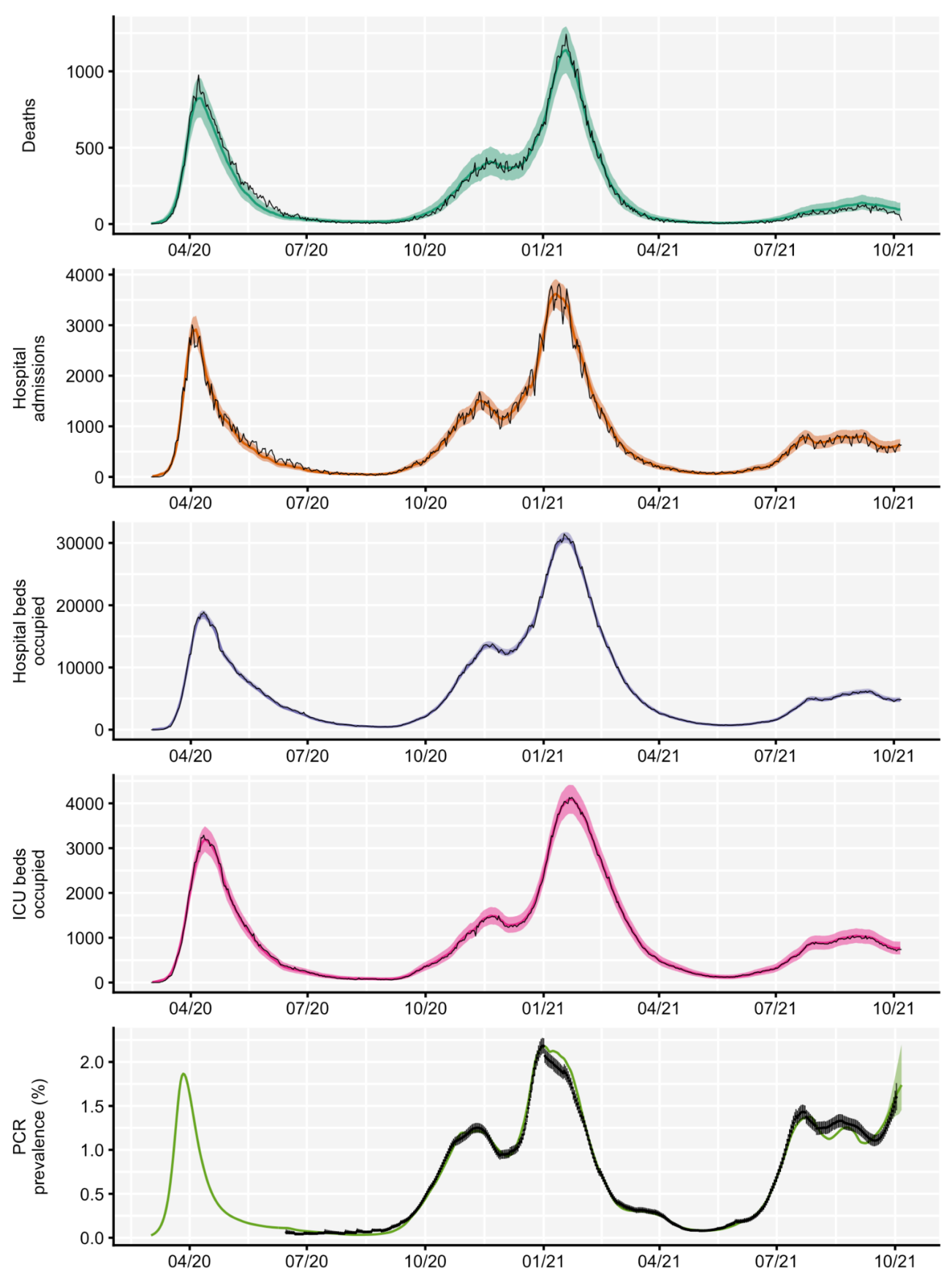

Figure 1. Comparison between aggregated model fits and epidemiological data from England between March 2020 and October 2021. Black lines show reported data, with vertical black lines showing 95\% confidence intervals for PCR prevalence. Coloured lines and shaded areas show medians and $90 \%$ interquantile ranges from the fitted model. The original model fitting is done independently for each NHS England region, with the aggregated model output for the whole of England shown here. COVID-19 deaths data was provided by the UK Health Security Agency (UKHSA) and hospital admissions, hospital and ICU bed occupancy data was provided by NHS England. These data sources are unpublished and not publicly available, but are closely aligned with the UK Government's COVID-19 dashboard. PCR prevalence data was obtained from the Office for National Statistics' COVID-19 Infection Survey $(\mathrm{ONS}-\mathrm{CIS})^{13}$. ICU $=$ intensive care unit. NHS = National Health Service. 
medRxiv preprint doi: https://doi.org/10.1101/2021.11.22.21266584; this version posted November 24,2021 . The copyright holder for this preprint (which was not certified by peer review) is the author/funder, who has granted medRxiv a license to display the preprint in

It is made available under a CC-BY-NC-ND 4.0 International license .

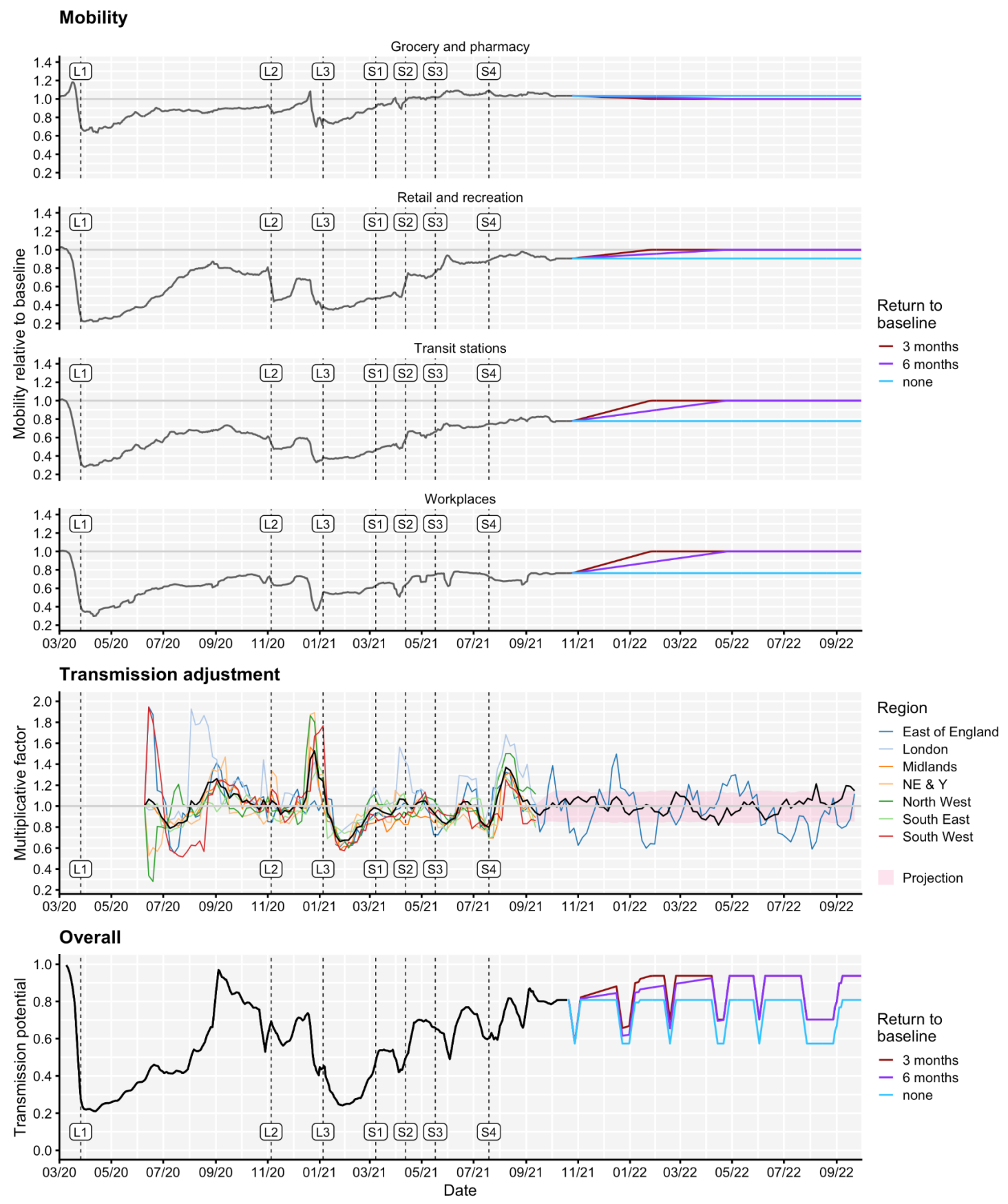

Figure 2. Mobility scenarios, transmission adjustments and overall transmission potential for the fitted model, shown from March 2020 to September 2022. Top: Historic Google Community Mobility data (grey) and assumed future mobility in England for no change (blue), a 3-month return to pre-pandemic baseline levels (red) and a 6-month return to pre-pandemic baseline levels (purple) scenarios used for model projections. Mobility indices are measured relative to baseline mobility levels recorded during early 2020, prior to the COVID-19 pandemic. The beginning of each lockdown and each roadmap Step is marked with a vertical dashed line and ' $L$ ' and 'S' labels, respectively. Middle: Fitted transmission adjustments by NHS England region and the average across regions (black), example projection for East of England (blue) and mean (black line) + interquartile range (red shaded) for projected transmission adjustments. Bottom: The "transmission potential" captures the overall impact of mobility and transmission adjustments on the time-varying potential for effective transmission, ignoring the impact of immunity and novel variants, though including the impact of school vacation periods. NE \& $Y=$ North East \& Yorkshire. NHS = National Health Service. 
medRxiv preprint doi: https://doi.org/10.1101/2021.11.22.21266584; this version posted November 24,2021 . The copyright holder for this preprint (which was not certified by peer review) is the author/funder, who has granted medRxiv a license to display the preprint in

It is made available under a CC-BY-NC-ND 4.0 International license .
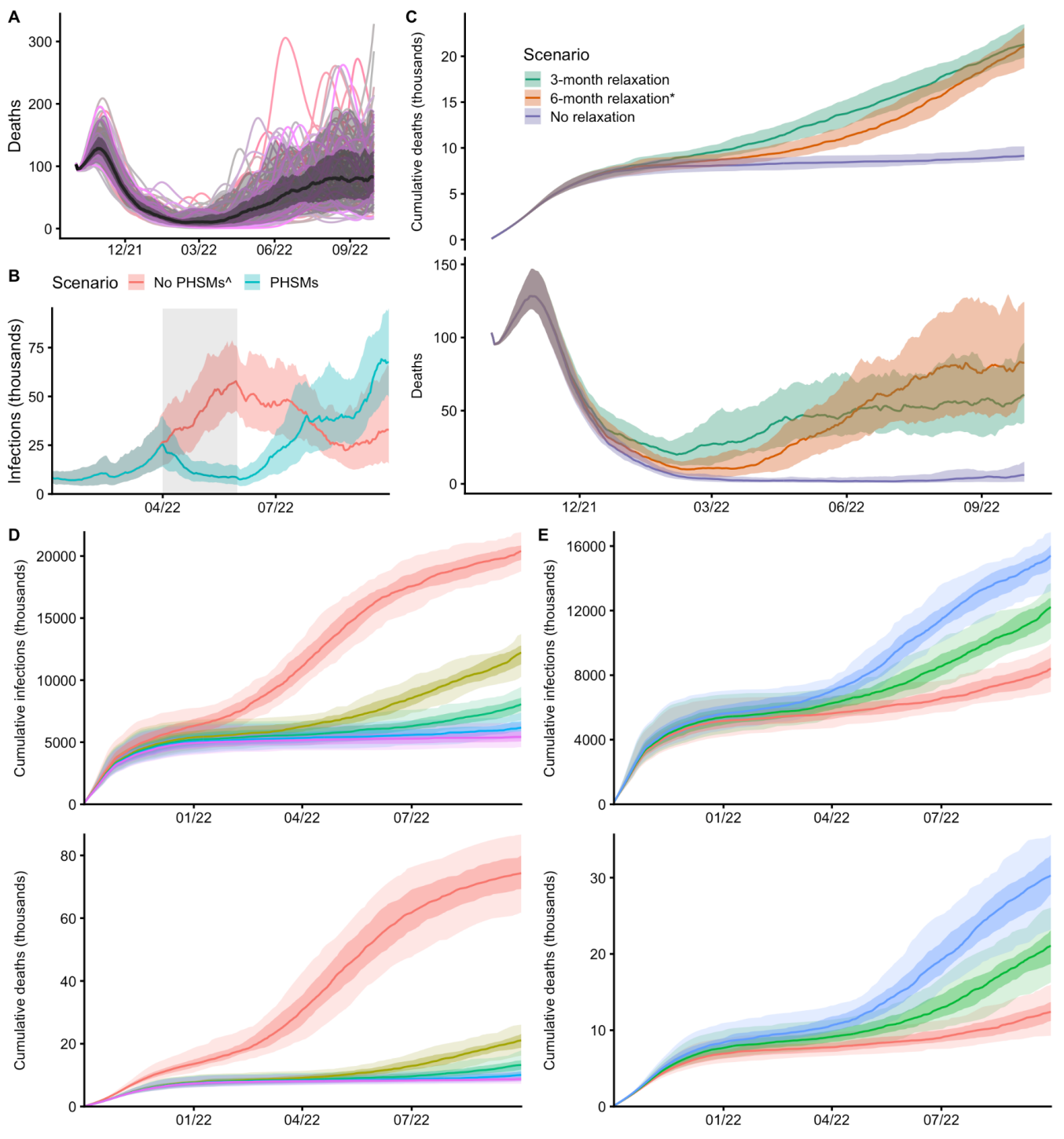

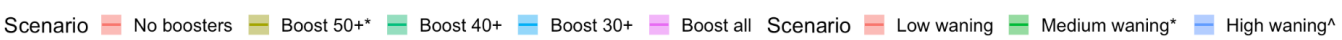

Figure 3. Summary of key results on uncertainty, public health and social measures (PHSMs), behaviour, booster vaccinations and waning immunity. A: The central scenario is shown here which assumes a 6-month return to baseline mobility levels, medium waning of vaccine protection (Table S3), $90 \%$ of vaccinated individuals aged 50 and above receiving booster vaccinations and $20 \%$ seasonality from 1 st April 2021 . The black line shows the median trajectory of COVID-19 deaths over time, with the shaded areas showing the $50 \%$ and $90 \%$ interquantile ranges. Individual model trajectories are plotted in coloured lines. B: The effect of PHSMs on projected SARS-CoV-2 infections over time are shown with two scenarios. Both scenarios assume a 6-month return to baseline mobility levels, high waning of vaccine protection (Table S3), $90 \%$ of vaccinated individuals aged 50 and above receiving booster vaccinations and $20 \%$ seasonality from 1 st April 2021. The PHSMs scenario implements a combination of three PHSMs (Figures 4, S7) between 1st April and 31st May 2022. C: The effect of behaviour on COVID-19 deaths and cumulative deaths over time is shown with three scenarios for future mobility: a 3-month and a 6-month return to baseline levels, and a no change scenario. All three scenarios assume medium waning (Table S3), 90\% of vaccinated individuals aged 50 and above receiving booster vaccinations and $20 \%$ seasonality from 1st April 2021. D: The effect of booster vaccination policy on cumulative infections and deaths over time is shown with five scenarios for booster policies. All five scenarios assume a 6-month return to baseline mobility, medium waning (Table S3) and 20\% seasonality from 1st April 2021. E: The effect of waning vaccine protection on cumulative infections and deaths over time is shown with three scenarios for waning (Table S3). All three scenarios assume a 6-month return to baseline mobility, $90 \%$ of vaccinated individuals aged 50 and above receiving booster vaccinations and 20\% seasonality from 1st April 2021. Scenarios marked with an asterisk $\left({ }^{*}\right)$ are equivalent, and scenarios marked with a caret $\left({ }^{\wedge}\right)$ are equivalent. 
medRxiv preprint doi: https://doi.org/10.1101/2021.11.22.21266584; this version posted November 24 , 2021. The copyright holder for this preprint (which was not certified by peer review) is the author/funder, who has granted medRxiv a license to display the preprint in

It is made available under a CC-BY-NC-ND 4.0 International license .

October 2021 to September 2022

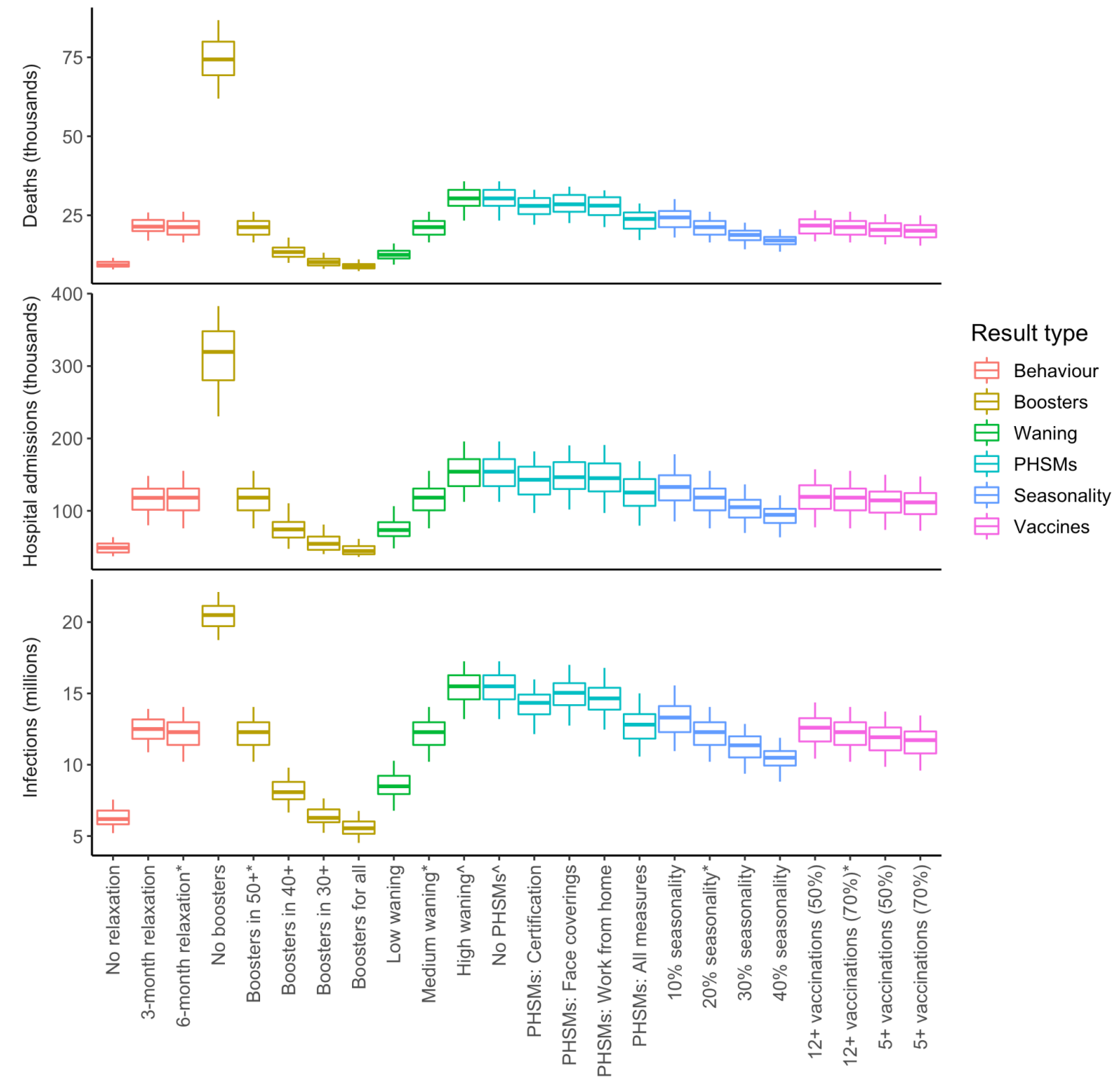

Figure 4. Summary of projected cumulative numbers of COVID-19 deaths, hospital admissions and infections in England between October 2021 and September 2022, across all scenarios considered. Each box plot shows the projected median, 5th, 25th, 75th and 95th percentile values across all simulations for the relevant scenario. Scenarios are coloured according to the result type (behaviour, booster vaccination policy, waning vaccine protection (Table S3), public health and social measures (PHSMs), seasonality, and vaccination policy for children). Behavioural scenarios assume medium waning vaccine protection (Table S3), 90\% of vaccinated individuals aged 50 and above receiving booster vaccinations and $20 \%$ seasonality from 1 st April 2021. Booster vaccination policy scenarios assume a 6-month return to baseline mobility levels, medium waning (Table S3), and $20 \%$ seasonality from 1st April 2021. Waning vaccine protection scenarios assume a 6-month return to baseline mobility levels, $90 \%$ of vaccinated individuals aged 50 and above receiving booster vaccinations and $20 \%$ seasonality from 1st April 2021. PHSM scenarios assume a 6-month return to baseline mobility levels, high waning vaccine protection (Table S3), and $20 \%$ seasonality from 1 st April 2021 . Seasonality scenarios assume a 6-month return to baseline mobility levels, medium waning vaccine protection (Table S3), and $90 \%$ of vaccinated individuals aged 50 and above receiving booster vaccinations. Vaccination of children scenarios assume a 6-month return to baseline mobility levels, medium waning vaccine protection (Table S3), $90 \%$ of individuals aged 50 and above receiving booster vaccinations and $20 \%$ seasonality from 1 st April 2021. A full list of scenarios and assumptions is given in the supplementary material (Table S6). Scenarios marked with an asterisk $\left(^{*}\right)$ are equivalent, and scenarios marked with a caret $\left(^{\wedge}\right)$ are equivalent. 
medRxiv preprint doi: https://doi.org/10.1101/2021.11.22.21266584; this version posted November 24 , 2021. The copyright holder for this preprint (which was not certified by peer review) is the author/funder, who has granted medRxiv a license to display the preprint in

It is made available under a CC-BY-NC-ND 4.0 International license

\section{Discussion}

We have fitted a deterministic compartmental model of SARS-CoV-2 transmission to data on COVID-19 deaths, hospital admissions, hospital bed and ICU bed occupancy, PCR prevalence, sero-prevalence, and the emergence and spread of the Alpha B.1.1.7 and Delta B.1.617.2 variants, incorporating additional data on vaccination coverage and behaviour over time. Projecting forwards to September 2022, we have considered a number of uncertainties around behaviour, booster vaccination policy, waning levels of vaccine protection over time, seasonality, and different policy options for vaccination of children. We have also considered the temporary reintroduction of PHSMs to suppress future projected rises in SARS-CoV-2 transmission.

Modelled levels of immunity in England (both from natural infection and induced by COVID-19 vaccinations) suggest that SARS-CoV-2 transmission will fall in the Autumn of 2021, but there remains significant uncertainty around the extent and the timescale to which immunity wanes. In addition, the projected winter dynamics depend on the current wave of transmission being large enough to deplete most susceptible individuals. Our model has estimated the number of daily infections in October 2021 to be up to 3 times larger than the number of daily reported cases on the COVID-19 dashboard ${ }^{2}$. We also assume that all individuals being administered their first COVID-19 vaccinations go on to receive a second dose. Currently 12-15 year olds in England are being recommended the first COVID-19 vaccine dose only ${ }^{7}$.

The majority of scenarios considered project resurgences in transmission occurring later in 2022. However, none of these resurgences are expected to reach the levels of hospital admissions and deaths seen in 2020 and 2021, largely due to high levels of vaccine and natural protection in the population (Fig. S10). Large reductions in the levels of protection conferred by COVID-19 vaccines over time have the potential to lead to substantial resurgences in transmission, particularly if no measures are implemented in response. Administering booster vaccinations to all individuals who have received first and second COVID-19 vaccinations provides a medium- to long-term solution towards mitigating future resurgences of SARS-CoV-2 community transmission. The re-introduction of PHSMs such as work-from-home policies can suppress projected resurgences, but are only considered as temporary measures here. Once PHSMs are relaxed, SARS-CoV-2 transmission is projected to resurge again. However, delaying a resurgence can give time to introduce further measures, to increase vaccine uptake and to allow advances in treatment of COVID-19 to occur.

The World Health Organization has stated that "administration of booster doses will exacerbate inequities by driving up demand and consuming scarce supply while priority populations in some countries, or subnational settings, have not yet received a primary vaccination series" ${ }^{14}$. Given that England has largely relaxed PHSMs against COVID-19 since July 2021, and given current vaccine supply constraints globally, it may be more equitable to implement PHSMs in England to suppress SARS-CoV-2 transmission in the 
medRxiv preprint doi: https://doi.org/10.1101/2021.11.22.21266584; this version posted November 24 , 2021. The copyright holder for this preprint (which was not certified by peer review) is the author/funder, who has granted medRxiv a license to display the preprint in

It is made available under a CC-BY-NC-ND 4.0 International license .

short-term whilst sharing vaccine doses with countries that have not yet vaccinated their most vulnerable populations with a primary dose.

There are a number of limitations in this work which are important to consider. The extent to which immunity from natural infection and from vaccination wanes is uncertain. Individuals may retain very long-term protection against severe outcomes, but have faster rates of waning against less severe outcomes such as mild or asymptomatic infection. We model waning vaccine protection in a way that initially allows protection against different outcomes to be reduced to different extents. Individuals can then return to being entirely susceptible from the vaccinated-and-waned state or from the naturally infected and recovered state (see assumed rates of waning in Table S4). We have parameterised waning rates in relation to measured reductions in protection against severe outcomes, but our assumption that individuals return to being completely naive to infection may still be overly pessimistic. We have not attempted to explore the dynamics of waning immunity from natural infection here in detail. Throughout, we assume identical levels of protection are conferred from natural infection and from vaccination across individuals of all ages. It is likely that protection will differ from person to person and that more clinically vulnerable individuals may have lower levels of protection or faster reductions in protection. Further, we do not consider any differences in vaccine coverage by risk group.

This work assumes that no new variants of SARS-CoV-2 possessing any kind of transmission advantage emerge in the future. As we have seen with the Alpha B.1.1.7 and Delta B.1.617.2 VOCs in England (Figs. S2, S3), novel VOCs with transmission advantages can spread to dominance very quickly, and this could have substantial implications for the future dynamics of COVID-19. In addition to future emergence of VOCs, it is impossible to predict future policy or behavioural changes with any certainty. It remains unclear whether mobility and behaviour will return to the same levels seen prior to the COVID-19 pandemic. We have considered one scenario where behaviour remains largely unchanged, and two scenarios in which mobility increases to pre-pandemic levels in either 3 months or 6 months to capture this uncertainty. In addition to longer-term changes, we are not able to forecast shorter-term behavioural changes that have been observed in the historic data, e.g. around Christmas of 2021 and during the Euro 2020 football tournament in the summer of 2021 (Fig. 2). Behavioural changes can also occur in response to awareness of a growing or declining epidemic ${ }^{15,16}$, which is something that we do not capture in any forward projections.

It is clear that the extent to which immunity, both derived from natural infection and from COVID-19 vaccination, wanes will become extremely important in the medium- to long-term. It is crucial to improve our current understanding of the dynamics of SARS-CoV-2 immunity and to consider the consequences of this on community transmission in the context of varying levels of PHSMs and vaccination coverage, both in England and worldwide. 
medRxiv preprint doi: https://doi.org/10.1101/2021.11.22.21266584; this version posted November 24 , 2021. The copyright holder for this preprint (which was not certified by peer review) is the author/funder, who has granted medRxiv a license to display the preprint in

It is made available under a CC-BY-NC-ND 4.0 International license

\section{Methods}

\section{Epidemiological model}

We use an age-structured and region-specific deterministic compartmental model of SARS-CoV-2 transmission, building on previous work $^{17-19}$. Geographic structure is by NHS England region and age groups are divided into 5-year age bands from 0-4 to 70-74 years, with an additional age group comprising individuals aged 75 years and over. The model tracks three variants of SARS-CoV-2 to capture wild-type, Alpha B.1.1.7 and Delta B.1.617.2 variants separately. We model vaccination against SARS-CoV-2 with separate compartments for two vaccine products, for each of the viral vector and mRNA-based COVID-19 vaccines in use in England. The model also captures the administration of booster vaccinations, and waning immunity derived from natural infection and vaccination. $A$ full description of assumptions related to vaccine protection against different outcomes and waning immunity is provided in the Supplementary Material and in Tables S2 - S4.

Hospital admissions and occupancy data were provided by NHS England and deaths, immunisations and variant data were provided by the UK Health Security Agency (UKHSA). These data sources are unpublished and not public, but are closely aligned with healthcare, deaths and vaccinations data on the UK Government COVID-19 Dashboard². Seroprevalence data were obtained from the UK Biobank ${ }^{20}$ and the REACT-2 study ${ }^{21}$, and seroprevalence and PCR positivity data were obtained from the the Office for National Statistics COVID-19 Infection Survey (ONS-CIS) ${ }^{13,22}$.

The age-specific probability of clinical symptoms is adopted from a study using data from 6 countries $^{23}$. The age-specific probability of hospital admission, ICU admission, and death given infection are fitted to data from England, with the relative rates by age group based on data collected by a large meta-analysis of the COVID-19 infection fatality rate ${ }^{24}$ and based on data collected by ISARIC (the CO-CIN study) for England ${ }^{17}$, then adjusted to better match observed hospitalisations and deaths in England (see Model fitting). Each of these age-specific probabilities of severe outcomes is allowed to vary over the course of the epidemic in England and vary between pre-existing variants and Alpha B.1.1.7. For the third variant Delta B.1.617.2, we assume that the probability of severe outcomes is twice that of Alpha B.1.1.7, in line with estimates from Public Health Scotland and UKHSA ${ }^{25}$. A full description of fitted and assumed parameters is provided in Tables S5A and S5B.

The model uses Google Community Mobility data ${ }^{26}$ to capture mobility in various settings: workplaces, retail \& recreation venues, transit stations, and grocery \& pharmacy locations. In turn, the relationship between mobility data and social contact rates is derived from the historical relationship between Google Community Mobility indices and social contact rates as measured by the CoMix study in $2020^{17}$. School openings and closings are accounted for in contacts among school-aged children, university-aged young adults and school/university staff. We assume that schools in England follow their traditional schedules (i.e. are closed during holiday periods), and we combine these assumptions with school attendance data in England up to July $2021^{27}$. To reflect the introduction of mass testing within educational 
medRxiv preprint doi: https://doi.org/10.1101/2021.11.22.21266584; this version posted November 24 , 2021. The copyright holder for this preprint (which was not certified by peer review) is the author/funder, who has granted medRxiv a license to display the preprint in

It is made available under a CC-BY-NC-ND 4.0 International license .

facilities in the Spring of 2021, we have assumed an additional $30 \%$ reduction in transmission related to educational settings between the reopening of schools on 8th March 2021 and school closures in July 2021. This reduction in transmission is reflected in the model with a $30 \%$ reduction in school-related contacts. Seasonality is modelled as a sinusoidally-varying multiplier on transmission with the peak occurring on January 1 st and the trough on July 1 st of each year. By default, we assume the amplitude of the seasonal component is $20 \%$ from trough to peak.

\section{Model fitting}

The model is fitted using a two-stage process. In the first stage, the model parameters are fitted by Bayesian inference using Markov chain Monte Carlo (MCMC) to reported regional data on hospital admissions, hospital and intensive care unit (ICU) bed occupancy, seroprevalence, PCR positivity, and deaths within 28 days of a patient's first positive SARS-CoV-2 test, as well as to data tracking the emergence and spread of the Alpha B.1.1.7 variant (the frequency of S-gene target failure in PCR tests) in late 2020 and of the Delta B.1.617.2 variant (the frequency of Delta in genomic sequencing data) in 2021. We use the DE-MCMC algorithm ${ }^{28}$ implemented in $\mathrm{C}++$ (see analysis code). The introduction time and relative transmissibility of both the Alpha and Delta variants are fitted for each geographic region in the model. We use data recording the number of first COVID-19 vaccine doses delivered by age, geography and vaccine product from 8th December 2020 to 3rd October 2021 to inform the fraction of first-dose vaccinated individuals in each age group, NHS England region and by vaccine type over time. Additionally, in this initial stage, 14 additional parameters are fitted to define a "transmission multiplier" function, with each of the 14 parameters defining a stepwise change in transmission at fixed six-week intervals from 12th April 2020 to 10th October 2021. This transmission multiplier function allows the modelled epidemic trajectory to better capture changes in SARS-CoV-2 transmission over time, and reflects residual changes in transmission that are not captured by mobility data alone, e.g. as resulting from changes in personal protective behaviours such as mask-wearing or from changes in social behaviour such as during holidays.

In the second stage of model fitting, a particle filtering algorithm ${ }^{29}$ is used to refine the "rough" transmission multiplier function, while holding other fitted model parameters constant, to achieve a more fine-scaled function with stepwise changes to the transmission multiplier every 5 days, instead of the cruder 6-week increment used in the initial stage of fitting. In the second stage, the transmission multiplier is fitted as a random walk on a logarithmic scale, that is, multiplicative increments to the transmission multiplier are proposed rather than absolute levels.

The same likelihood is used for Bayesian inference in both stages of the model fitting process. In particular, the likelihood allows the infection fatality rate (IFR), infection hospitalisation rate (IHR), and infection critical-illness rate (ICR) to vary over the course of the epidemic, to reflect changes in treatment success, admissions criteria, and availability of hospital resources over time. To achieve this, the model's initial output of deaths and hospital burdens, which are based upon a fixed IFR, IHR, and ICR (except as modified by variant-specific characteristics and by vaccine protection), are treated as the prior 
medRxiv preprint doi: https://doi.org/10.1101/2021.11.22.21266584; this version posted November 24 , 2021. The copyright holder for this preprint (which was not certified by peer review) is the author/funder, who has granted medRxiv a license to display the preprint in

It is made available under a CC-BY-NC-ND 4.0 International license .

expectation for deaths and hospital burdens on each day. This expectation is used as the mean of a gamma distribution, with standard deviation set to 0.3 times the mean, which, in turn, is taken as the prior distribution for the mean of a Poisson distribution from which the observed burden for a given day is assumed to be drawn. This process allows the IFR/IHR/ICR to change over time, while not straying too far from the expected burden based upon the underlying fixed IFR/IHR/ICR.

\section{Model assumptions}

Vaccine effectiveness - We base our vaccine effectiveness assumptions on the latest available evidence (Tables S2, S7, S8). These may be subject to change in future work, as new evidence emerges. We currently treat individuals who have been and will be vaccinated with Moderna vaccines the same as individuals receiving Pfizer vaccines. We model individuals who have received different vaccine products (e.g. AstraZeneca and Pfizer/Moderna) and one or two vaccine doses separately, assuming separate efficacy estimates for each category. We additionally consider individuals who have received two vaccine doses but no booster dose as having reduced levels of protection, with various scenarios considered in relation to vaccine protection (Table S3).

We model vaccine protection against five separate outcomes: infection, disease (i.e. symptomatic infection), hospitalisation, mortality and onward transmission following a breakthrough infection (i.e. when an individual who has vaccine protection becomes infected). We assume the same vaccine effectiveness for the first two SARS-CoV-2 variants considered in the model (pre-Alpha B.1.1.7 and Alpha B.1.1.7), and separate specific vaccine effectiveness estimates for the Delta B.1.617.2 variant, shown in Table S2. Tables S7 and S8 show summaries of the relevant evidence we have used to guide our assumptions on vaccine effectiveness against the Alpha B.1.1.7 and pre-existing variants of SARS-CoV-2 and against the Delta B.1.617.2 variant, respectively.

Our assumptions about the levels of vaccine protection for individuals who have received two vaccine doses but no booster dose, and their protection has waned, are shown in Table S3. To parametrise these reductions in vaccine protection, we have referred to Andrews et al. ${ }^{12}$, using the measured percentage change in protection for ages $16+$ against symptomatic disease and hospitalisation between week 1 and 20+ weeks and against death between week 1 and 15-19 weeks. We have used the vaccine product specific percentage changes in protection against symptomatic disease to scale our estimates against infection and disease, and the percentage changes in protection against hospitalisation and death to scale our estimates against hospitalisation and death, respectively. We have calculated the mean percentage change across these three values for each vaccine product and used this change to scale our estimates for vaccine protection against onward transmission. Since we model an individual's average duration in second dose protection as 29.3 weeks, before they are either boosted and remain at two-dose levels of protection or are not boosted and wane, we consider these baseline assumptions for the levels of protection in the waned state as being optimistic, and we refer to this as the 'less waning' scenario. Therefore, we also consider an additional two scenarios for two-dose vaccinated-and-waned individuals, where 
medRxiv preprint doi: https://doi.org/10.1101/2021.11.22.21266584; this version posted November 24 , 2021. The copyright holder for this preprint (which was not certified by peer review) is the author/funder, who has granted medRxiv a license to display the preprint in

It is made available under a CC-BY-NC-ND 4.0 International license .

we assume $25 \%$ (moderate waning) and $50 \%$ (more waning) reductions to the waned estimates shown in Table S2.

Waning immunity - We model waning protection from SARS-CoV-2 infection developed from natural infection and vaccination. For waning protection from natural infection, we assume identical rates of waning for all three virus variants and for all age groups (Table S4). Once individuals who have recovered from natural infection wane, they return to a susceptible disease state; thus we model waning of natural immunity against different endpoints (infection, disease, hospitalisation, deaths and onward transmission) at the same rate. In contrast to previous reports, we no longer model individuals waning from second vaccination protection directly back to being susceptible. To account for booster vaccinations, upon leaving the second dose state, individuals either receive a booster vaccine and return to second dose levels of protection, or move into a third state with reduced levels of vaccine protection across different outcomes (see Table S3). This third state corresponds to individuals who have received two vaccine doses followed by waning of their vaccine protection. Once individuals have moved into this waned state with reduced levels of vaccine protection, they are also allowed to wane back to being susceptible, with different rates considered for each vaccine product (Table S4). The assumed percentage loss in reduction here is based on measured percentage changes in vaccine protection against hospitalisation for each vaccine product in Andrews et al. ${ }^{12}$

\section{Vaccination, waning and intervention scenarios}

To produce forward projections, the model requires information about future contact rates and vaccination rates. We base our assumptions on how social contact rates might be expected to change by referring to historical mobility data ${ }^{26}$ and making assumptions about future mobility until September 2022 (Fig. 2). Mobility levels have been gradually increasing since March 2022 but have still not returned to pre-pandemic levels. Hence we consider three scenarios: we project current levels of mobility forwards (i.e. no change), and we consider a return to pre-pandemic baseline levels of mobility within a period of 3 months and a period of 6 months. Where we consider the introduction of PHSMs such as increases in mask-wearing and advice to work from home, we introduce changes to either all contacts or work-related contacts.

The time-varying transmission multiplier also needs to be projected forwards for model projections. This is done by using the $\mathrm{R}$ package forecast ${ }^{30}$ to fit an ARIMA model to the fitted transmission multiplier function (using the function auto.arima), then using random forecasts of the resulting ARIMA model for each new projection. This process of using different realisations of the projected transmission multiplier is what produces most of the variability among different runs of each scenario (Fig. 3A).

For future first-dose vaccinations, we generate vaccine schedules according to assumed future vaccine supply (i.e. number of doses available) and uptake limits per 5-year age group. We assume that first-dose vaccination uptake limits in individuals aged 20 years and above have already been reached, so no future first doses are delivered to these age groups. Our basecase scenarios assume that uptake is limited at $70 \%$ for individuals aged 
medRxiv preprint doi: https://doi.org/10.1101/2021.11.22.21266584; this version posted November 24 , 2021. The copyright holder for this preprint (which was not certified by peer review) is the author/funder, who has granted medRxiv a license to display the preprint in

It is made available under a CC-BY-NC-ND 4.0 International license .

12-19, delivering future first doses first to the 15-19 age group up to the uptake limit, followed by 12-14 year olds. Future first doses per day are distributed into the seven NHS England regions in proportion to population size. The allocated number of first doses per day, per region and per age group are divided into specified proportions of vaccine products relevant to each age group. Any doses remaining after this process are carried over to the next age group down (up to the relevant uptake limit), the next NHS England region, or the next day, or are left unallocated in the schedule and recorded as leftover doses.

Individuals remain in first- and second-dose vaccine states for durations drawn from pre-specified waiting time distributions. The distribution for the time spent in the first-dose vaccine state is based on measured delays between first and second doses in the UKHSA vaccination data, separated into two periods (before and after the JCVI issued guidance on widening the dosing gap from 3 weeks to a maximum of 12 weeks). Upon leaving the first-dose vaccine state, individuals transition into the second-dose vaccine state with increased levels of protection (Table S2). The distribution governing the duration that individuals have second-dose levels of vaccine protection is chosen to match the time between the start of the COVID-19 vaccination rollout (8th December 2020) and the start of the COVID-19 booster dose rollout (24th September 2021) less the assumed average duration of first-dose protection. Upon leaving the second-dose vaccine state, individuals either move into a vaccinated-and-waned state with reduced levels of protection specific to the vaccine they received (Table S3), or receive a booster vaccination and return to second-dose levels of protection assumed for the mRNA vaccines (Table S2). This assumption reflects the fact that all booster vaccinations in England are either the Pfizer/BioNTech or Moderna mRNA vaccines and evidence finding higher immunogenicity for individuals receiving Pfizer/BioNTech following Oxford-AstraZeneca, compared with individuals receiving both Oxford-AstraZeneca vaccine doses ${ }^{31}$.

For modelling potential PHSMs, we use the high waning scenario from Figure 3 in the main text (see also Table S3) as a baseline to represent a larger wave of infection. We assume that the measures announced are temporary, and are in force between 1st April and 31st May 2022.

We consider three potential contingency measures. "Certification" represents the introduction of vaccination or testing requirements for nightclub attendance. We model the impact of the certification policy by assuming that it will lead to an increase in vaccination rates among young people, as has been observed in some other European countries ${ }^{32}$. Certification policy in France was associated with a $2.5 \%$ increase in uptake across the entire population, particularly in ages $12-29$. We assume that a similar policy in England could also increase vaccine uptake by $2.5 \%$, specifically in individuals aged $18-29$, and that this increase in uptake would occur between 14 days before and 7 days after the start of the contingency period.

"Face coverings" represents the reintroduction of mask-wearing. Since late August 2021, mask wearing in England has decreased by approximately $30 \%{ }^{33}$. We assume that this decrease could be completely reversed by the face covering measure, and that this would result in a $7.5 \%$ reduction in $\mathrm{R}$ over the contingency period, comparable to the effect size 
medRxiv preprint doi: https://doi.org/10.1101/2021.11.22.21266584; this version posted November 24 , 2021. The copyright holder for this preprint (which was not certified by peer review) is the author/funder, who has granted medRxiv a license to display the preprint in

It is made available under a CC-BY-NC-ND 4.0 International license .

measured in a regression analysis across 92 regions $^{34}$ and a cluster randomized trial in Bangladesh $^{35}$.

Finally, "Work from home" represents the reimposition of work from home guidance over the contingency period. We model this by returning work mobility indices to their value the week of March 15th 2021, after Step 1 of the roadmap.

\section{Vaccine schedules}

First-dose vaccine schedules are generated by combining PHE/UKHSA data on vaccines delivered up to the 3rd of October 2021 in England with future schedules based on a number of assumptions related to vaccine product distribution, vaccine supply and vaccine uptake. The number of future first doses supplied for each day in the schedule are distributed into the seven NHS England regions according to the population size of each region. Existing first-dose vaccination uptake for ages $20+$ are used as uptake limits such that no future first doses are delivered to these age groups. For central scenarios considered here, we assume uptake is limited at $70 \%$ for individuals aged $12-19$, delivering future first doses first to the 15-19 age group up to the uptake limit followed by 12-14 year olds. The allocated number of first doses per day, per region and per age group are divided into specified proportions of vaccine products relevant to each age group (see 'Vaccine mix' section). If doses are remaining after this process, leftover doses are carried over to either the next age group down up to the relevant uptake limit, the next NHS England region, the next day, or are not allocated in the schedule and are recorded as leftover doses.

First-dose vaccinated individuals transition into second dose protection according to a distribution controlling the duration of vaccinated individuals remaining at first-dose levels of protection. This distribution is chosen according to measured delays between first and second doses in the PHE/UKHSA vaccination data, separated into two periods (before and after the $\mathrm{JCVI}$ issued guidance on widening the dosing gap from 3 weeks to a maximum of 12 weeks). The duration that individuals have second-dose levels of protection is chosen to match the time between the start of the COVID-19 vaccination rollout (8th December 2020) and the start of the COVID-19 booster dose rollout (24th September 2021), less the time duration already assumed at first dose levels of protection. At the end of their second dose protection, individuals either receive booster doses and retain second-dose levels of protection, or move into a waned state with reduced levels of vaccine protection.

For projecting vaccination forwards, future first-dose vaccine supply is assumed to be 150,000 doses per week for England. The following proportions of each vaccine product are used in the vaccine schedules projected forwards: $75 \%$ Pfizer and $25 \%$ Moderna for $<40$ year olds, and $60 \%$ AstraZeneca, 30\% Pfizer and 10\% Moderna for 40+ year olds. 
medRxiv preprint doi: https://doi.org/10.1101/2021.11.22.21266584; this version posted November 24 , 2021. The copyright holder for this preprint (which was not certified by peer review) is the author/funder, who has granted medRxiv a license to display the preprint in

\section{Contributions}

RCB and NGD accessed and verified the data and conducted the analyses. All authors contributed to study design and drafting of the manuscript.

\section{Declaration of interests}

RCB, NGD, MJ and WJE are participants of the UK's Scientific Pandemic Influenza Group on Modelling. WJE attends the UK's Scientific Advisory Group for Emergencies. All authors declare no competing interests.

See supplementary material for working group authors and acknowledgments.

\section{Statement on data availability}

Analysis code and data will be made available upon publication at: https://github.com/rosannaclairebarnard/newcovid3

\section{Funding statement}

The following funding sources are acknowledged as providing funding for the named authors. This project has received funding from the European Union's Horizon 2020 research and innovation programme - project EpiPose (101003688: RCB, MJ, WJE) and the UK Medical Research Council (MC_PC_19065: NGD, WJE). It was also partly funded by the Bill \& Melinda Gates Foundation (INV-003174 and INV-016832: MJ) and the National Institute for Health Research (NIHR) (Health Protection Research Unit for Immunisation NIHR200929: NGD, MJ; Health Protection Research Unit in Modelling and Health Economics NIHR200908: MJ, WJE; PR-OD-1017-20002: WJE).

\section{Ethics}

Ethical approval for this research was given by the London School of Hygiene \& Tropical Medicine Ethics Committee, project ID: 22828. 
medRxiv preprint doi: https://doi.org/10.1101/2021.11.22.21266584; this version posted November 24, 2021. The copyright holder for this preprint (which was not certified by peer review) is the author/funder, who has granted medRxiv a license to display the preprint in It is made available under a CC-BY-NC-ND 4.0 International license.

\section{Supplementary material}

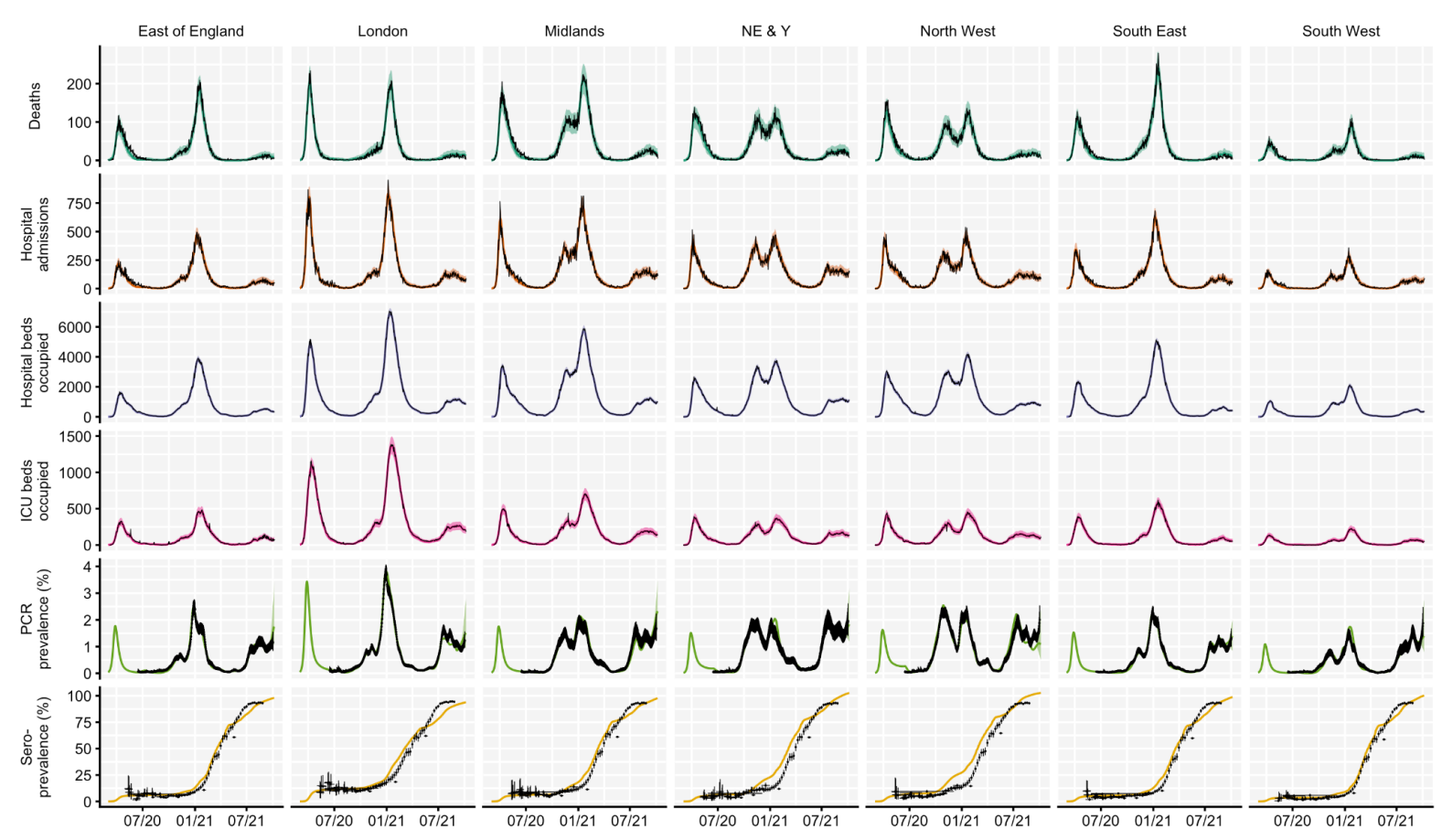

Figure S1. Regional model fit using epidemiological data from NHS England regions between March 2020 and October 2021. Black lines show reported data, with vertical black lines showing 95\% confidence intervals for PCR prevalence and seroprevalence estimates. Coloured lines and shaded areas show medians and $90 \%$ interquantile ranges from the fitted model. COVID-19 deaths data was provided by the UK Health Security Agency (UKHSA) and hospital admissions, hospital and ICU bed occupancy data was provided by NHS England. These data sources are unpublished and not publicly available, but are closely aligned with the UK Government's COVID-19 dashboard ${ }^{2}$. PCR prevalence data was obtained from the Office for National Statistics' COVID-19 Infection Survey (ONS-CIS) ${ }^{13}$. Seroprevalence data was obtained from the UK Biobank ${ }^{36}$, REACT-2 study ${ }^{37}$ and from the ONS-CIS ${ }^{13,22}$. ICU $=$ intensive care unit. NHS $=$ National Health Service. 
medRxiv preprint doi: https://doi.org/10.1101/2021.11.22.21266584; this version posted November 24 , 2021. The copyright holder for this preprint (which was not certified by peer review) is the author/funder, who has granted medRxiv a license to display the preprint in

It is made available under a CC-BY-NC-ND 4.0 International license.

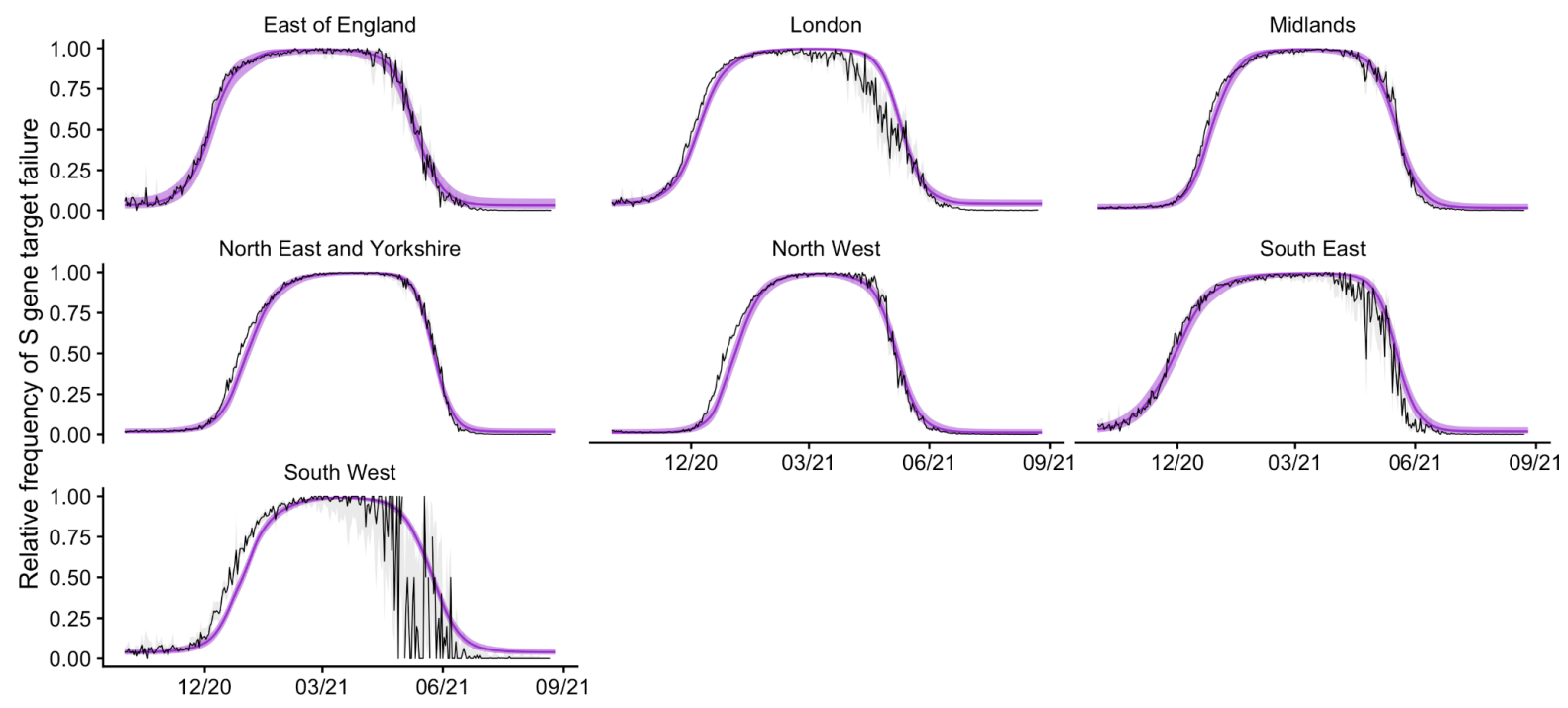

Figure S2. Regional model fit to the B.1.1.7 Alpha variant of concern using S-gene target failure data from NHS England regions between March 2020 and October 2021. Black lines show reported data, with grey shaded regions showing 95\% confidence intervals for the relative frequency of S-gene target failure in Pillar 2 PCR confirmed cases. Coloured lines and shaded areas show medians and 95\% interquantile ranges from the fitted model. S-gene target failure data was provided by the UK Health Security Agency (UKHSA). This data source is unpublished and not publicly available. NHS = National Health Service.

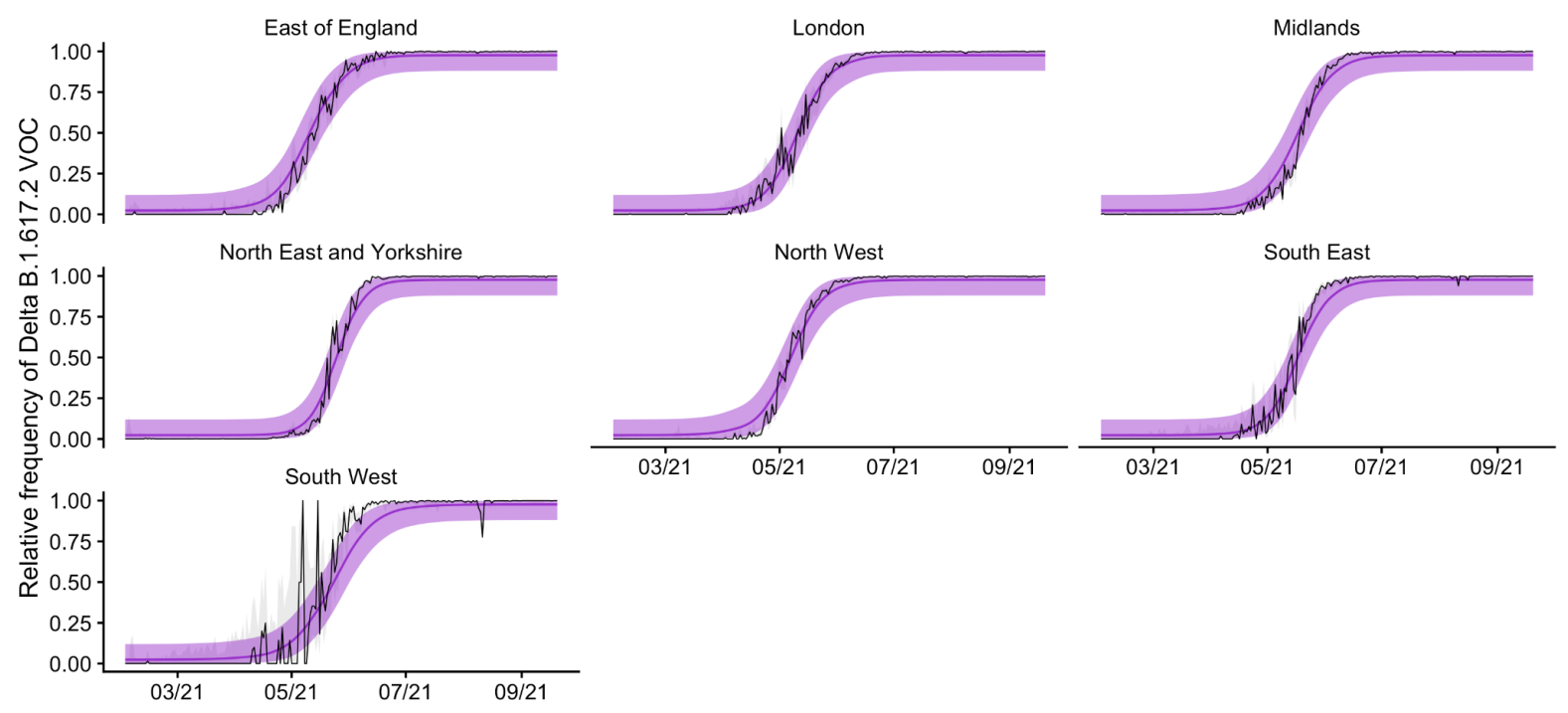

Figure S3. Regional model fit to the B.1.617.2 Delta variant of concern using genomic sequencing data from NHS England regions between February and October 2021. Black lines show reported data, with grey shaded regions showing 95\% confidence intervals for the relative frequency of Delta B.1.617.2 variant of concern in sequenced Pillar 2 PCR confirmed cases. Coloured lines and shaded areas show medians and 95\% interquantile ranges from the fitted model. Sequencing data was provided by the UK Health Security Agency (UKHSA). This data source is unpublished and not publicly available. NHS = National Health Service. 
medRxiv preprint doi: https://doi.org/10.1101/2021.11.22.21266584; this version posted November 24,2021 . The copyright holder for this preprint (which was not certified by peer review) is the author/funder, who has granted medRxiv a license to display the preprint in It is made available under a CC-BY-NC-ND 4.0 International license.
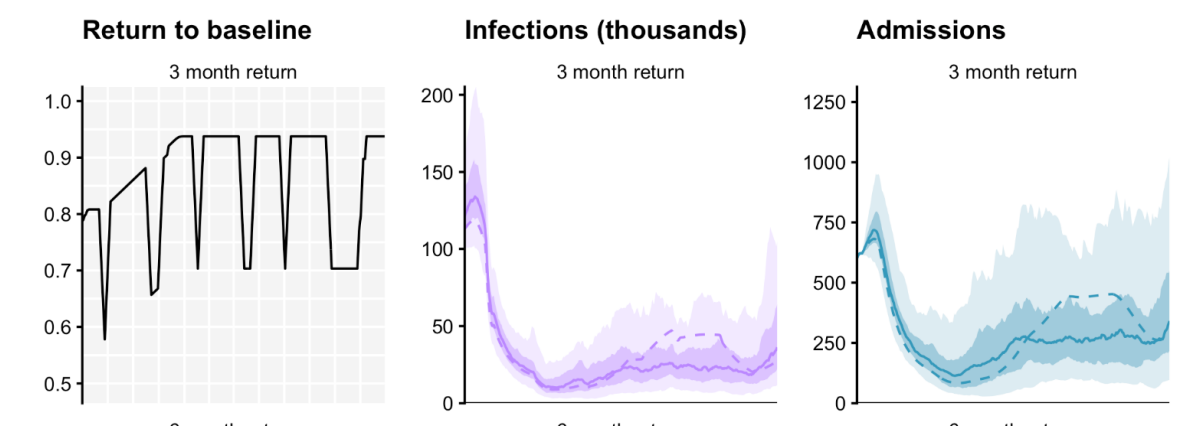

Deaths
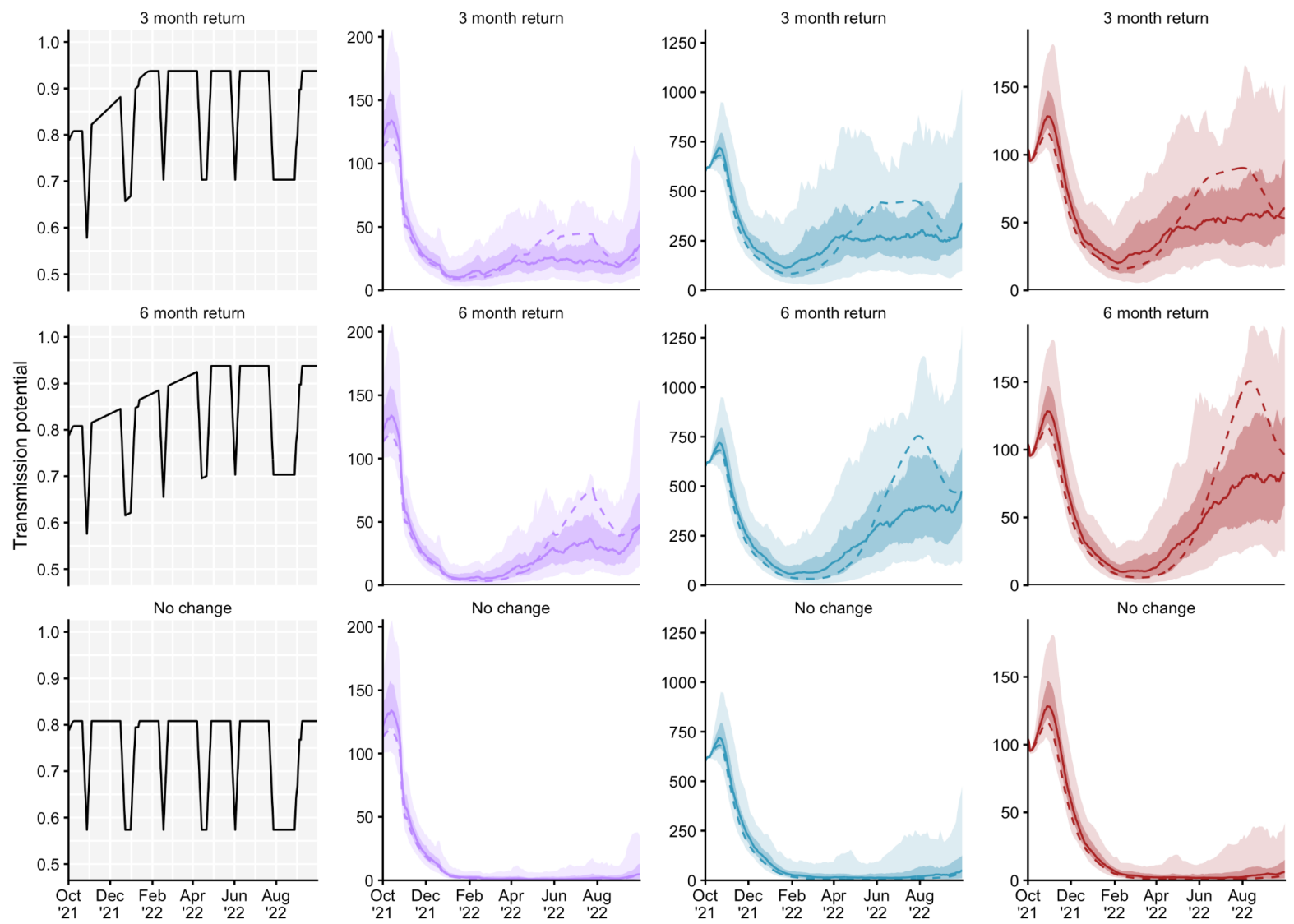

Short-term outcomes from 1 Oct 2021 to 31 Dec 2021

\begin{tabular}{|l|l|l|l|}
\hline Return to baseline & Infections & Admissions & Deaths \\
\hline $\mathbf{3}$ months & $5,720,000(4,560,000-7,240,000)$ & $39,000(33,000-52,500)$ & $7,920(6,540-10,400)$ \\
\hline $\mathbf{6}$ months & $5,520,000(4,420,000-7,040,000)$ & $37,700(31,700-50,200)$ & $7,760(6,420-10,000)$ \\
\hline none & $5,310,000(4,280,000-6,890,000)$ & $36,500(31,000-48,900)$ & $7,650(6,320-9,870)$ \\
\hline
\end{tabular}

Longer-term outcomes from 1 Oct 2021 to 30 Sept 2022

\begin{tabular}{|l|l|l|l|}
\hline Return to baseline & Infections & Admissions & Deaths \\
\hline 3 months & $12,500,000(10,900,000-13,900,000)$ & $118,000(80,100-148,000)$ & $21,400(17,000-25,900)$ \\
\hline $\mathbf{6}$ months & $12,300,000(10,200,000-14,100,000)$ & $118,000(75,800-155,000)$ & $21,200(16,400-26,100)$ \\
\hline none & $6,190,000(5,200,000-7,560,000)$ & $49,000(37,300-63,700)$ & $9,230(7,880-11,500)$ \\
\hline
\end{tabular}

Figure S4. Impact of mobility changes on projected dynamics of SARS-CoV-2 transmission in England from October 2021 to September 2022. Top: Possible trajectories for infections, admissions, and deaths are simulated for different rates of return to pre-pandemic baseline levels. The shaded areas and solid lines show the $90 \%$ interquantile range, the $50 \%$ interquantile range, and the median for each time point, while the dashed line shows one sample trajectory. All scenarios assume moderate waning of vaccine protection (see Table S3), $90 \%$ of individuals aged 50 and above who are vaccinated against COVID-19 receive additional booster vaccines, and $20 \%$ seasonality introduced from 1st April 2021. Tables: the total number of infections, admissions, and deaths, over the shorter term (October to December 2021) and the longer term (October 2021 to September 2022), shown to 3 significant figures. 
medRxiv preprint doi: https://doi.org/10.1101/2021.11.22.21266584; this version posted November 24, 2021. The copyright holder for this preprint (which was not certified by peer review) is the author/funder, who has granted medRxiv a license to display the preprint in It is made available under a CC-BY-NC-ND 4.0 International license.
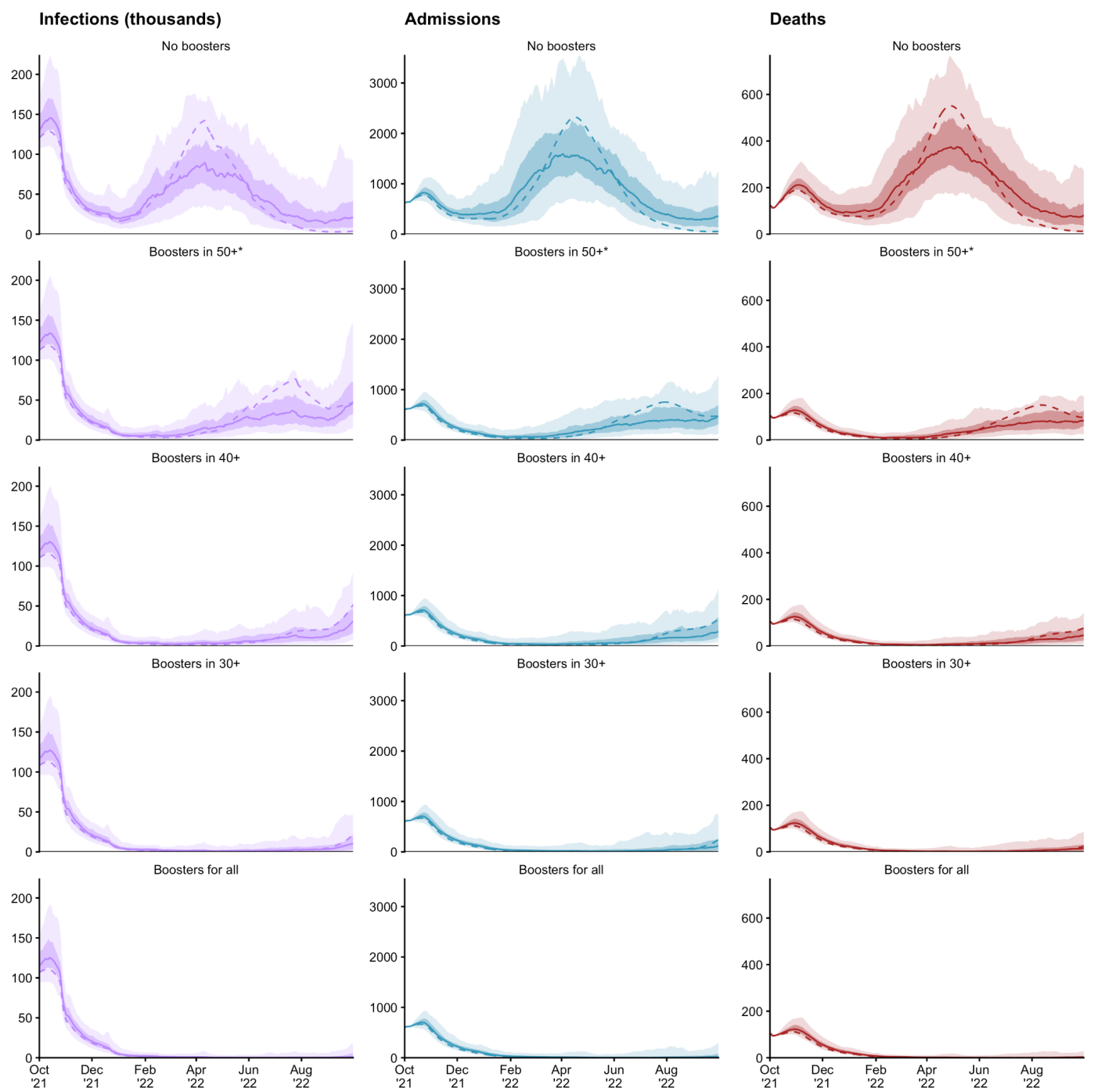

Short-term outcomes from 1 Oct 2021 to 31 Dec 2021

\begin{tabular}{|l|l|l|l|}
\hline Booster scenario & Infections & Admissions & Deaths \\
\hline No boosters & $6,430,000(5,100,000-8,040,000)$ & $51,500(43,200-74,800)$ & $13,600(10,900-18,600)$ \\
\hline Boost $\mathbf{5 0 + *}$ & $5,520,000(4,420,000-7,040,000)$ & $37,700(31,700-50,200)$ & $7,760(6,420-10,000)$ \\
\hline Boost 40+ & $5,320,000(4,260,000-6,830,000)$ & $37,000(31,300-49,600)$ & $7,600(6,290-9,810)$ \\
\hline Boost 30+ & $5,170,000(4,120,000-6,660,000)$ & $36,500(30,900-49,200)$ & $7,480(6,190-9,670)$ \\
\hline Boost all & $5,060,000(4,030,000-6,540,000)$ & $36,200(30,600-48,900)$ & $7,410(6,120-9,580)$ \\
\hline
\end{tabular}

Longer-term outcomes from 1 Oct 2021 to 30 Sept 2022

\begin{tabular}{|l|l|l|l|}
\hline Booster scenario & Infections & Admissions & Deaths \\
\hline No boosters & $20,500,000(18,700,000-22,100,000)$ & $320,000(231,000-383,000)$ & $74,300(61,900-86,800)$ \\
\hline Boost $\mathbf{5 0 + *}$ & $12,300,000(10,200,000-14,100,000)$ & $118,000(75,800-155,000)$ & $21,200(16,400-26,100)$ \\
\hline Boost 40+ & $8,070,000(6,650,000-9,790,000)$ & $74,400(47,500-110,000)$ & $13,400(9,960-17,900)$ \\
\hline Boost 30+ & $6,280,000(5,230,000-7,640,000)$ & $54,500(40,200-81,100)$ & $10,100(8,060-13,200)$ \\
\hline Boost all & $5,550,000(4,520,000-6,770,000)$ & $44,500(36,300-61,300)$ & $8,820(7,350-11,100)$ \\
\hline
\end{tabular}



medRxiv preprint doi: https://doi.org/10.1101/2021.11.22.21266584; this version posted November 24,2021 . The copyright holder for this
preprint (which was not certified by peer review) is the author/funder, who has granted medRxiv a license to display the preprint in

It is made available under a CC-BY-NC-ND 4.0 International license.

Figure S5. Impact of booster vaccination strategies on projected dynamics of SARS-CoV-2 transmission in England from October 2021 to September 2022. Top: Possible trajectories for SARS-CoV-2 infections, hospital admissions and deaths are simulated until September 2022, with different assumptions used for age groups receiving COVID-19 booster vaccinations. The shaded areas and solid lines show the $90 \%$ interquantile range, the $50 \%$ interquantile range, and the median for each time point, while the dashed line shows a single sample trajectory. All scenarios assume that mobility returns to pre-pandemic baseline levels over a 6-month period, a medium rate of waning protection conferred by vaccines (Table S3), and seasonality of 20\% is introduced from 1st April 2021. The 'boosters for all' scenario is modelled as $90 \%$ of all individuals who receive initial COVID-19 vaccination being offered a booster vaccine at least 6 months following their second dose. Tables: the total number of infections, admissions, and deaths, over the shorter term (October to December 2021) and the longer term (October 2021 to September 2022), shown to 3 significant figures. 
medRxiv preprint doi: https://doi.org/10.1101/2021.11.22.21266584; this version posted November 24 , 2021. The copyright holder for this preprint (which was not certified by peer review) is the author/funder, who has granted medRxiv a license to display the preprint in It is made available under a CC-BY-NC-ND 4.0 International license .
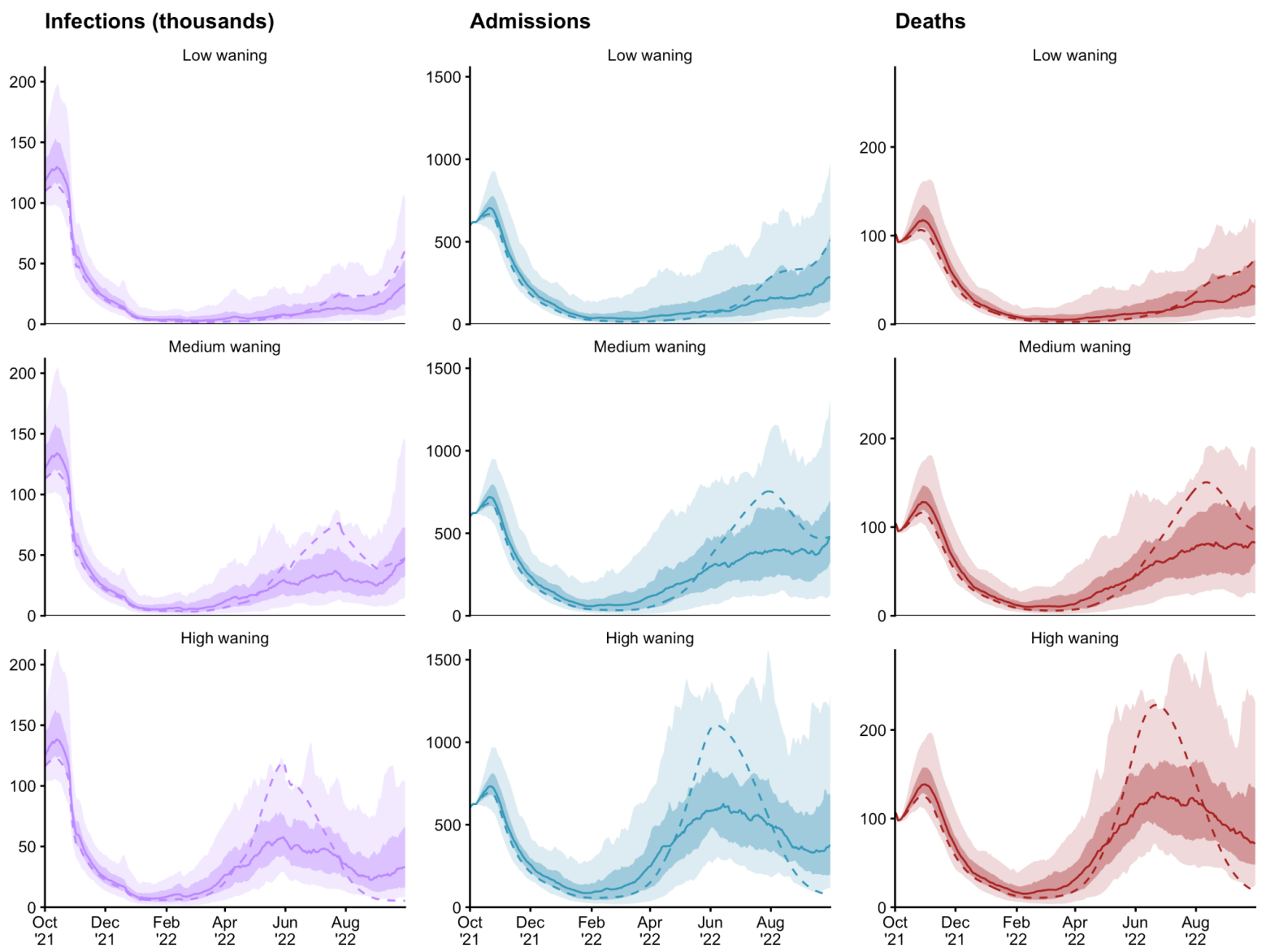

Short-term outcomes from 1 Oct 2021 to 31 Dec 2021

\begin{tabular}{|l|l|l|l|}
\hline Waning scenario & Infections & Admissions & Deaths \\
\hline Low & $5,300,000(4,230,000-6,800,000)$ & $35,900(30,400-48,200)$ & $7,020(5,820-9,030)$ \\
\hline Medium & $5,520,000(4,420,000-7,040,000)$ & $37,700(31,700-50,200)$ & $7,760(6,420-10,000)$ \\
\hline High & $5,740,000(4,610,000-7,280,000)$ & $39,100(33,300-52,500)$ & $8,460(6,980-11,000)$ \\
\hline
\end{tabular}

Longer-term outcomes from 1 Oct 2021 to 30 Sept 2022

\begin{tabular}{|l|l|l|l|}
\hline Waning scenario & Infections & Admissions & Deaths \\
\hline Low & $8,490,000(6,770,000-10,300,000)$ & $73,400(48,100-107,000)$ & $12,500(9,380-16,100)$ \\
\hline Medium & $12,300,000(10,200,000-14,100,000)$ & $118,000(75,800-155,000)$ & $21,200(16,400-26,100)$ \\
\hline High & $15,500,000(13,200,000-17,200,000)$ & $154,000(112,000-196,000)$ & $30,300(23,300-35,800)$ \\
\hline
\end{tabular}

Figure S6. Impact of waning of vaccine protection on projected dynamics of SARS-CoV-2 transmission in England from October 2021 to September 2022. Top: Possible trajectories for SARS-CoV-2 infections, hospital admissions and deaths are simulated until September 2022, with different assumptions used for the rate that vaccine protection wanes for individuals who do not receive a booster vaccination. The shaded areas and solid lines show the $90 \%$ interquantile range, the $50 \%$ interquantile range, and the median for each time point, while the dashed line shows a single sample trajectory. Assumptions for the low, medium and high waning scenarios are shown in Table S3. All scenarios assume that mobility returns to pre-pandemic baseline levels over a 6-month period, $90 \%$ of vaccinated individuals aged 50 and above receive a booster vaccination, and seasonality of $20 \%$ is introduced from 1st April 2021. Tables: the total number of infections, admissions, and deaths, over the shorter term (October to December 2021) and the longer term (October 2021 to September 2022), shown to 3 significant figures. 
medRxiv preprint doi: https://doi.org/10.1101/2021.11.22.21266584; this version posted November 24,2021 . The copyright holder for this preprint (which was not certified by peer review) is the author/funder, who has granted medRxiv a license to display the preprint in

It is made available under a CC-BY-NC-ND 4.0 International license .
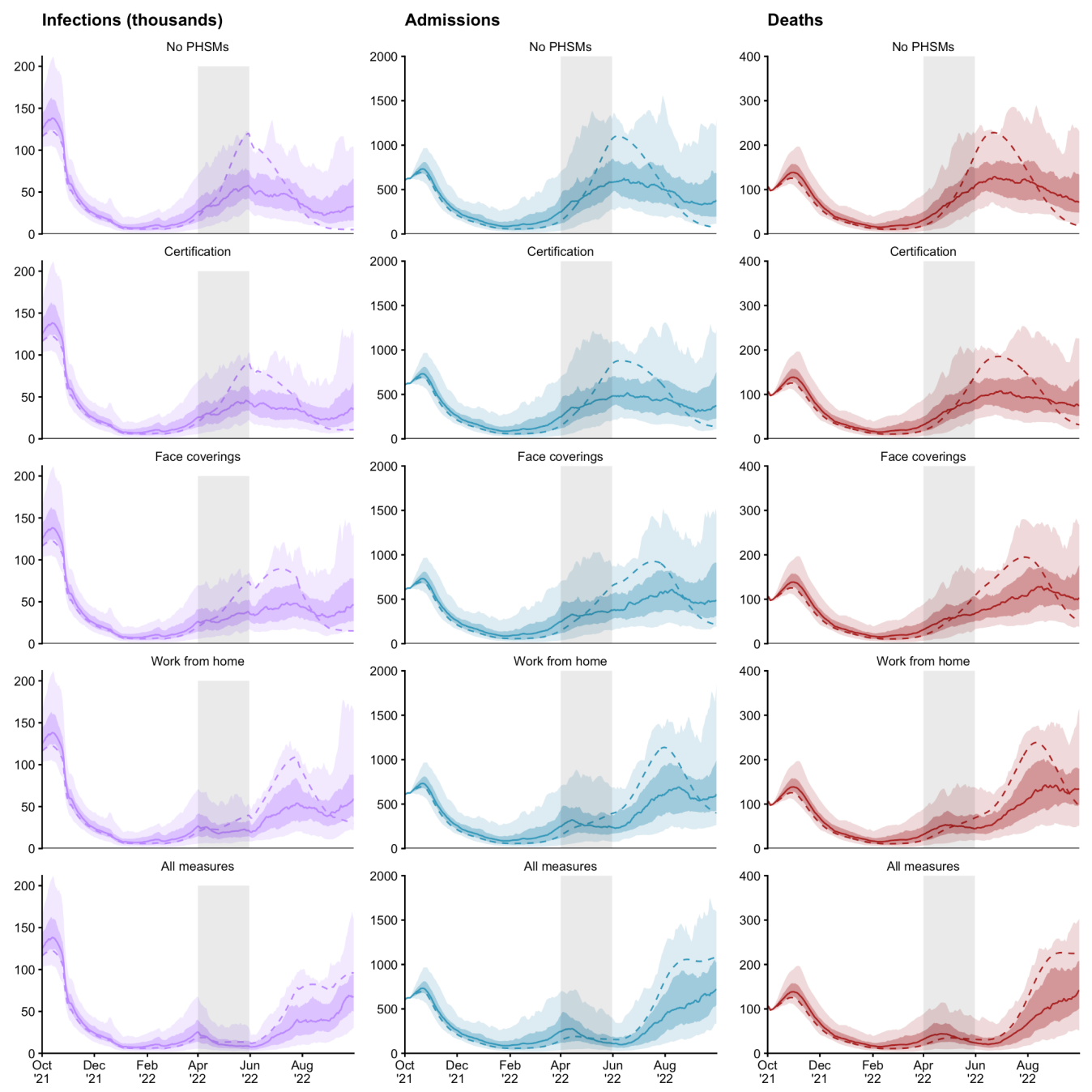

Longer-term outcomes from 1 Oct 2021 to 30 Sept 2022

\begin{tabular}{|l|l|l|l|}
\hline PHSM scenario & Infections & Admissions & Deaths \\
\hline No PHSMs & $15,500,000(13,200,000-17,200,000)$ & $154,000(112,000-196,000)$ & $30,300(23,300-35,800)$ \\
\hline Certification & $14,300,000(12,100,000-16,000,000)$ & $143,000(97,100-182,000)$ & $28,000(22,000-33,100)$ \\
\hline Face coverings & $15,000,000(12,700,000-17,000,000)$ & $146,000(102,000-190,000)$ & $28,500(22,500-34,000)$ \\
\hline Work from home & $14,600,000(12,500,000-16,800,000)$ & $145,000(97,100-191,000)$ & $28,100(21,200-32,900)$ \\
\hline All measures & $12,800,000(10,600,000-15,000,000)$ & $125,000(79,500-169,000)$ & $23,800(17,200-28,700)$ \\
\hline
\end{tabular}

Figure S7. Impact of public health and social measures (PHSMs) on projected dynamics of SARS-CoV-2 transmission in England from October 2021 to September 2022. Top: Possible trajectories for SARS-CoV-2 infections, hospital admissions and deaths are simulated until September 2022, with different public health and social measures introduced between 1st April and 31st May 2022 (grey shaded rectangle) to suppress projected rises in transmission. The shaded areas and solid lines show the $90 \%$ interquantile range, the $50 \%$ interquantile range, and the median for each time point, while the dashed line shows a single sample trajectory. All scenarios shown assume mobility returns to pre-pandemic baseline levels over a 6-month period, a high rate of waning vaccine protection for individuals who don't receive a booster vaccination (Table S3), 90\% of vaccinated individuals aged 50 and above receive a booster vaccination, and seasonality of $20 \%$ is introduced from 1st April 2021. Table: the total number of infections, admissions, and deaths between October 2021 and September 2022, shown to 3 significant figures. 
medRxiv preprint doi: https://doi.org/10.1101/2021.11.22.21266584; this version posted November 24, 2021. The copyright holder for this preprint (which was not certified by peer review) is the author/funder, who has granted medRxiv a license to display the preprint in It is made available under a CC-BY-NC-ND 4.0 International license.
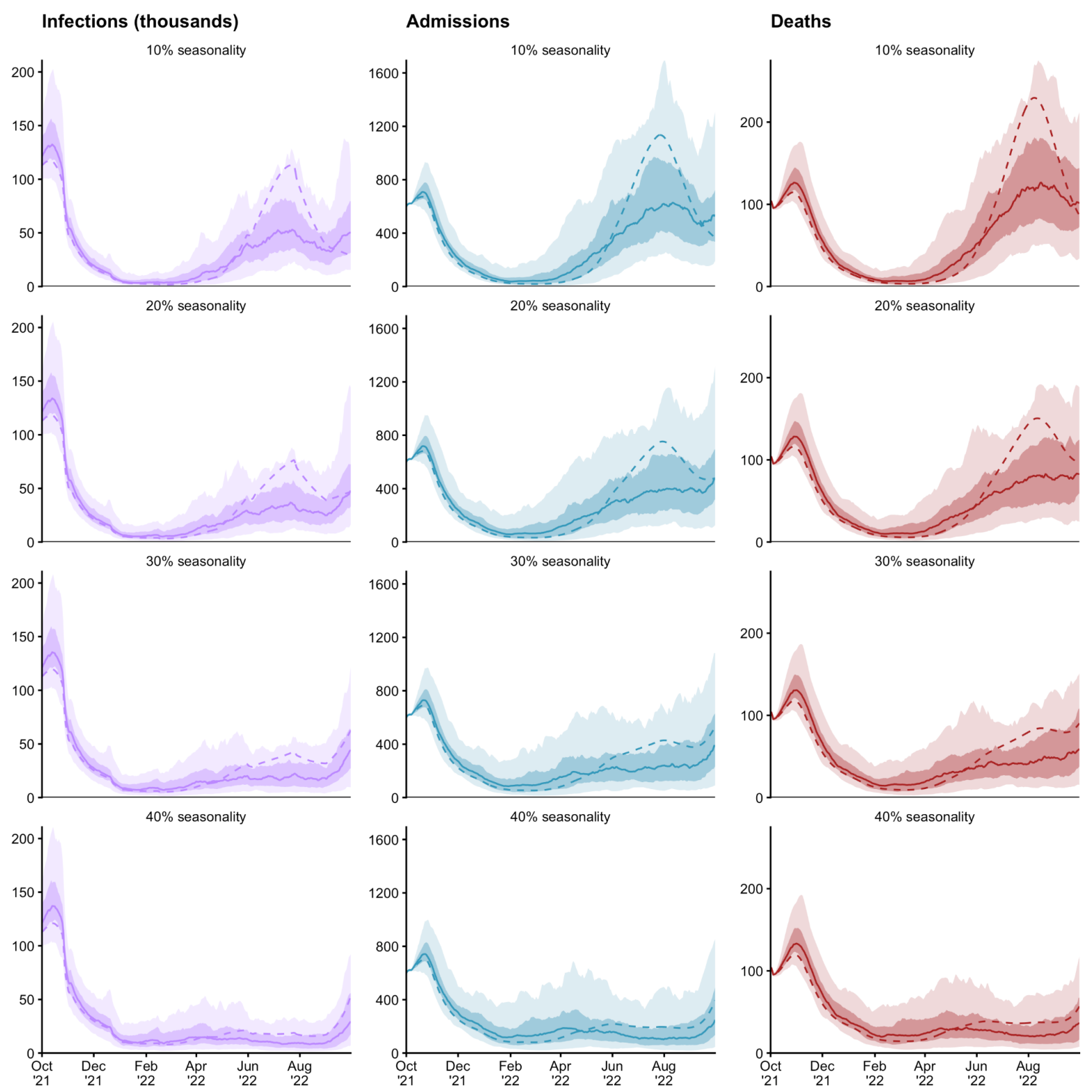

Short-term outcomes from 1 Oct 2021 to 31 Dec 2021

\begin{tabular}{|l|l|l|l|}
\hline Seasonality scenario & Infections & Admissions & Deaths \\
\hline $\mathbf{1 0} \%$ & $5,190,000(4,150,000-6,750,000)$ & $35,700(30,300-47,800)$ & $7,480(6,200-9,630)$ \\
\hline $\mathbf{2 0} \%$ & $5,520,000(4,420,000-7,040,000)$ & $37,700(31,700-50,200)$ & $7,760(6,420-10,000)$ \\
\hline $\mathbf{3 0} \%$ & $5,850,000(4,680,000-7,390,000)$ & $39,900(33,900-53,400)$ & $8,120(6,660-10,600)$ \\
\hline $\mathbf{4 0 \%}$ & $6,220,000(4,970,000-7,700,000)$ & $41,900(35,600-56,800)$ & $8,500(6,930-11,000)$ \\
\hline
\end{tabular}

Longer-term outcomes from 1 Oct 2021 to 30 Sept 2022

\begin{tabular}{|l|l|l|l|}
\hline Seasonality scenario & Infections & Admissions & Deaths \\
\hline $\mathbf{1 0} \%$ & $13,300,000(11,000,000-15,600,000)$ & $133,000(85,400-178,000)$ & $24,300(18,000-30,100)$ \\
\hline $\mathbf{2 0} \%$ & $12,300,000(10,200,000-14,100,000)$ & $118,000(75,800-155,000)$ & $21,200(16,400-26,100)$ \\
\hline $\mathbf{3 0} \%$ & $11,400,000(9,370,000-12,900,000)$ & $105,000(69,500-137,000)$ & $18,800(14,200-22,700)$ \\
\hline $\mathbf{4 0 \%}$ & $10,500,000(8,810,000-11,900,000)$ & $94,600(63,500-121,000)$ & $17,100(13,500-20,600)$ \\
\hline
\end{tabular}

Figure S8. Impact of seasonality on projected dynamics of SARS-CoV-2 transmission in 
medRxiv preprint doi: https://doi.org/10.1101/2021.11.22.21266584; this version posted November 24, 2021. The copyright holder for this preprint (which was not certified by peer review) is the author/funder, who has granted medRxiv a license to display the preprint in It is made available under a CC-BY-NC-ND 4.0 International license.

England from October 2021 to September 2022. Top: Possible trajectories for SARS-CoV-2 infections, hospital admissions and deaths are simulated until September 2022, with different assumptions made for the extent of seasonality in transmission. From top to bottom: $10 \%, 20 \%, 30 \%$ and $40 \%$ seasonality is introduced from 1 st April 2021. The shaded areas and solid lines show the $90 \%$ interquantile range, the $50 \%$ interquantile range, and the median for each time point, while the dashed line shows a single sample trajectory. All scenarios shown assume mobility returns to pre-pandemic baseline levels over a 6-month period, a medium rate of waning vaccine protection for individuals who don't receive a booster vaccination (Table S3), and $90 \%$ of vaccinated individuals aged 50 and above receive a booster vaccination. Tables: the total number of infections, admissions, and deaths, over the shorter term (October to December 2021) and the longer term (October 2021 to September 2022), shown to 3 significant figures. 
medRxiv preprint doi: https://doi.org/10.1101/2021.11.22.21266584; this version posted November 24, 2021. The copyright holder for this preprint (which was not certified by peer review) is the author/funder, who has granted medRxiv a license to display the preprint in It is made available under a CC-BY-NC-ND 4.0 International license.
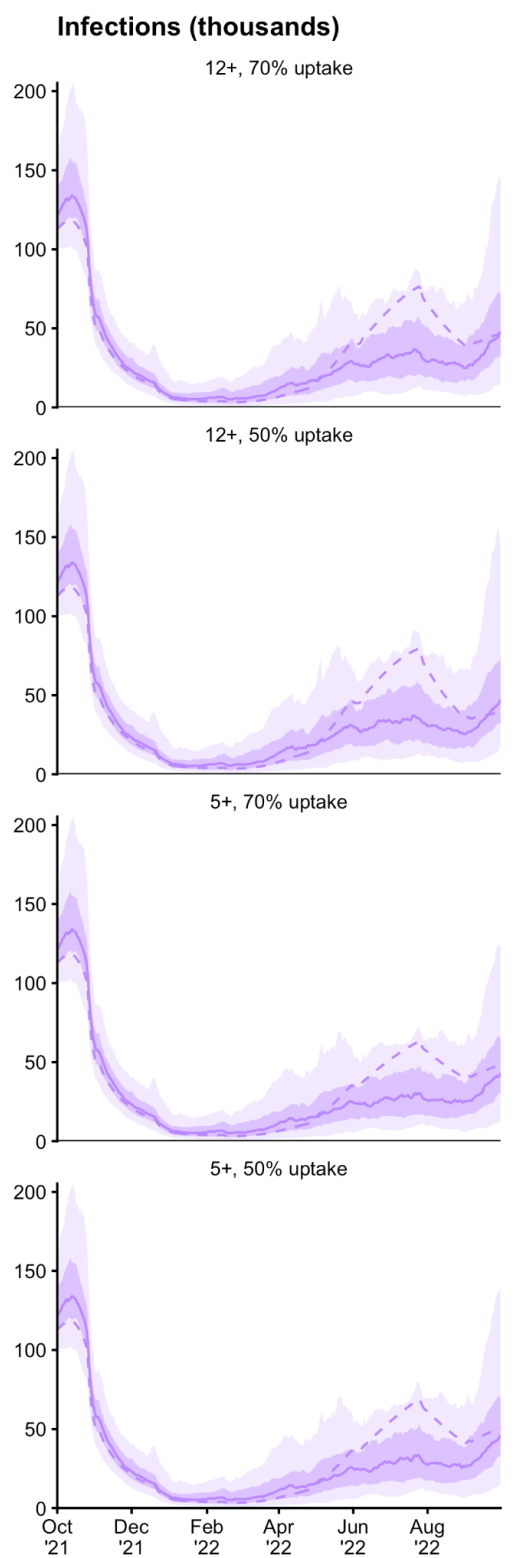

Admissions

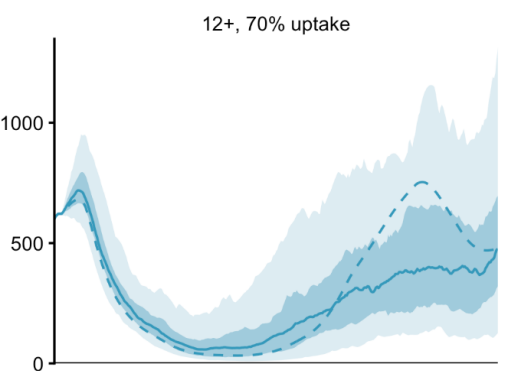

$12+, 50 \%$ uptake
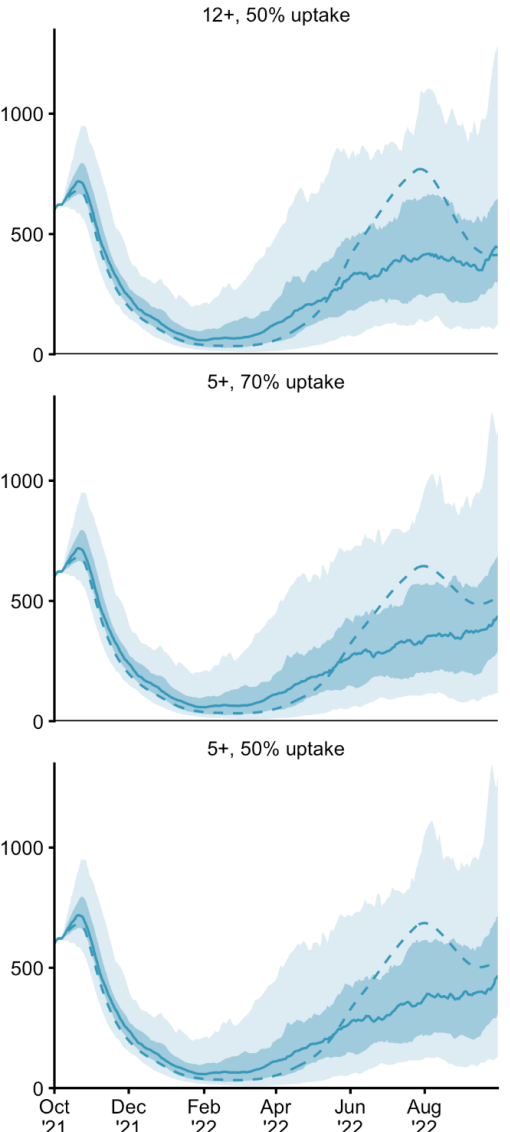

Deaths

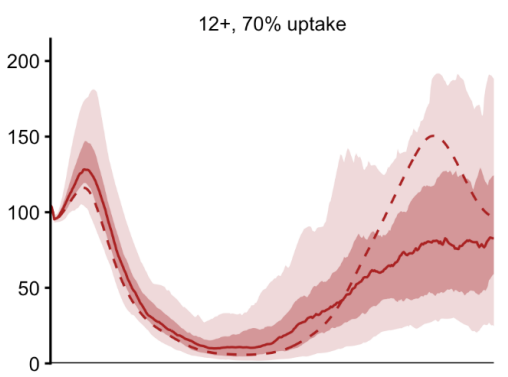

$12+, 50 \%$ uptake

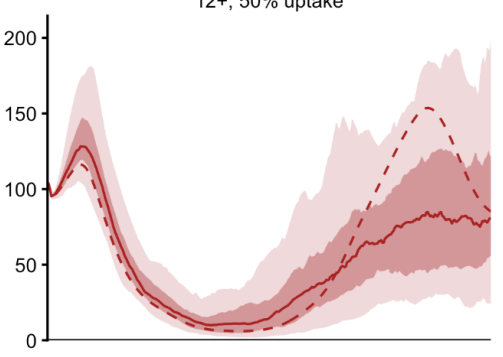

$5+, 70 \%$ uptake

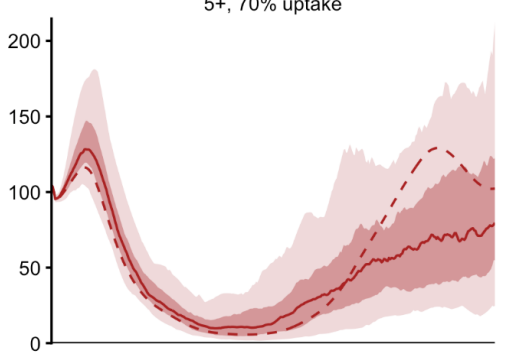

$5+, 50 \%$ uptake

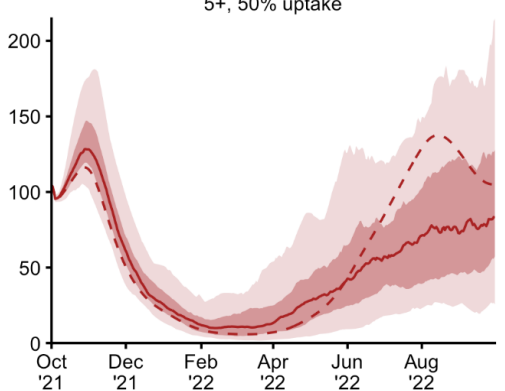

Short-term outcomes from 1 Oct 2021 to 31 Dec 2021

\begin{tabular}{|l|l|l|l|}
\hline Vaccination scenario & Infections & Admissions & Deaths \\
\hline $\mathbf{1 2 +}, \mathbf{7 0} \%$ uptake & $5,520,000(4,420,000-7,040,000)$ & $37,700(31,700-50,200)$ & $7,760(6,420-10,000)$ \\
\hline $\mathbf{1 2 +}, \mathbf{5 0} \%$ uptake & $5,520,000(4,420,000-7,040,000)$ & $37,600(31,700-50,200)$ & $7,760(6,420-10,000)$ \\
\hline $\mathbf{5 +}, \mathbf{7 0} \%$ uptake & $5,520,000(4,420,000-7,040,000)$ & $37,700(31,700-50,200)$ & $7,760(6,420-10,000)$ \\
\hline $\mathbf{5 + , 5 0 \%}$ uptake & $5,520,000(4,420,000-7,040,000)$ & $37,600(31,700-50,200)$ & $7,760(6,420-10,000)$ \\
\hline
\end{tabular}

Longer-term outcomes from 1 Oct 2021 to 30 Sept 2022

\begin{tabular}{|l|l|l|l|}
\hline Vaccination scenario & Infections & Admissions & Deaths \\
\hline $\mathbf{1 2 +}, \mathbf{7 0} \%$ uptake & $12,300,000(10,200,000-14,100,000)$ & $118,000(75,800-155,000)$ & $21,200(16,400-26,100)$ \\
\hline $\mathbf{1 2 +} \mathbf{5 0} \%$ uptake & $12,600,000(10,400,000-14,400,000)$ & $119,000(77,300-157,000)$ & $21,700(16,700-26,600)$ \\
\hline $\mathbf{5 + , 7 0 \%}$ uptake & $11,700,000(9,590,000-13,500,000)$ & $112,000(72,600-147,000)$ & $20,100(15,400-25,000)$ \\
\hline $\mathbf{5 +} \mathbf{5 0} \%$ uptake & $11,900,000(9,860,000-13,700,000)$ & $114,000(73,700-150,000)$ & $20,400(15,800-25,300)$ \\
\hline
\end{tabular}


medRxiv preprint doi: https://doi.org/10.1101/2021.11.22.21266584; this version posted November 24,2021 . The copyright holder for this preprint (which was not certified by peer review) is the author/funder, who has granted medRxiv a license to display the preprint in

It is made available under a CC-BY-NC-ND 4.0 International license.

Figure S9. Impact of vaccinating adolescents and children on projected dynamics of SARS-CoV-2 transmission in England from October 2021 to September 2022. Top: Possible trajectories for SARS-CoV-2 infections, hospital admissions and deaths are simulated until September 2022, with different assumptions made for vaccination strategies of adolescents and children and with different levels of vaccination coverage in those age groups. From top to bottom: vaccinating children aged $12-15$ at $70 \%$ uptake and at $50 \%$ uptake, and vaccinating children aged 5 and above at $70 \%$ uptake and at $50 \%$ uptake. The shaded areas and solid lines show the $90 \%$ interquantile range, the $50 \%$ interquantile range, and the median for each time point, while the dashed line shows a single sample trajectory. All scenarios shown assume mobility returns to pre-pandemic baseline levels over a 6-month period, a medium rate of waning vaccine protection for individuals who don't receive a booster vaccination (Table S3), 90\% of vaccinated individuals aged 50 and above receive a booster vaccination, and seasonality of $20 \%$ is introduced from 1st April 2021. Tables: the total number of infections, admissions, and deaths, over the shorter term (October to December 2021) and the longer term (October 2021 to September 2022), shown to 3 significant figures. 
medRxiv preprint doi: https://doi.org/10.1101/2021.11.22.21266584; this version posted November 24 , 2021. The copyright holder for this preprint (which was not certified by peer review) is the author/funder, who has granted medRxiv a license to display the preprint in

It is made available under a CC-BY-NC-ND 4.0 International license .

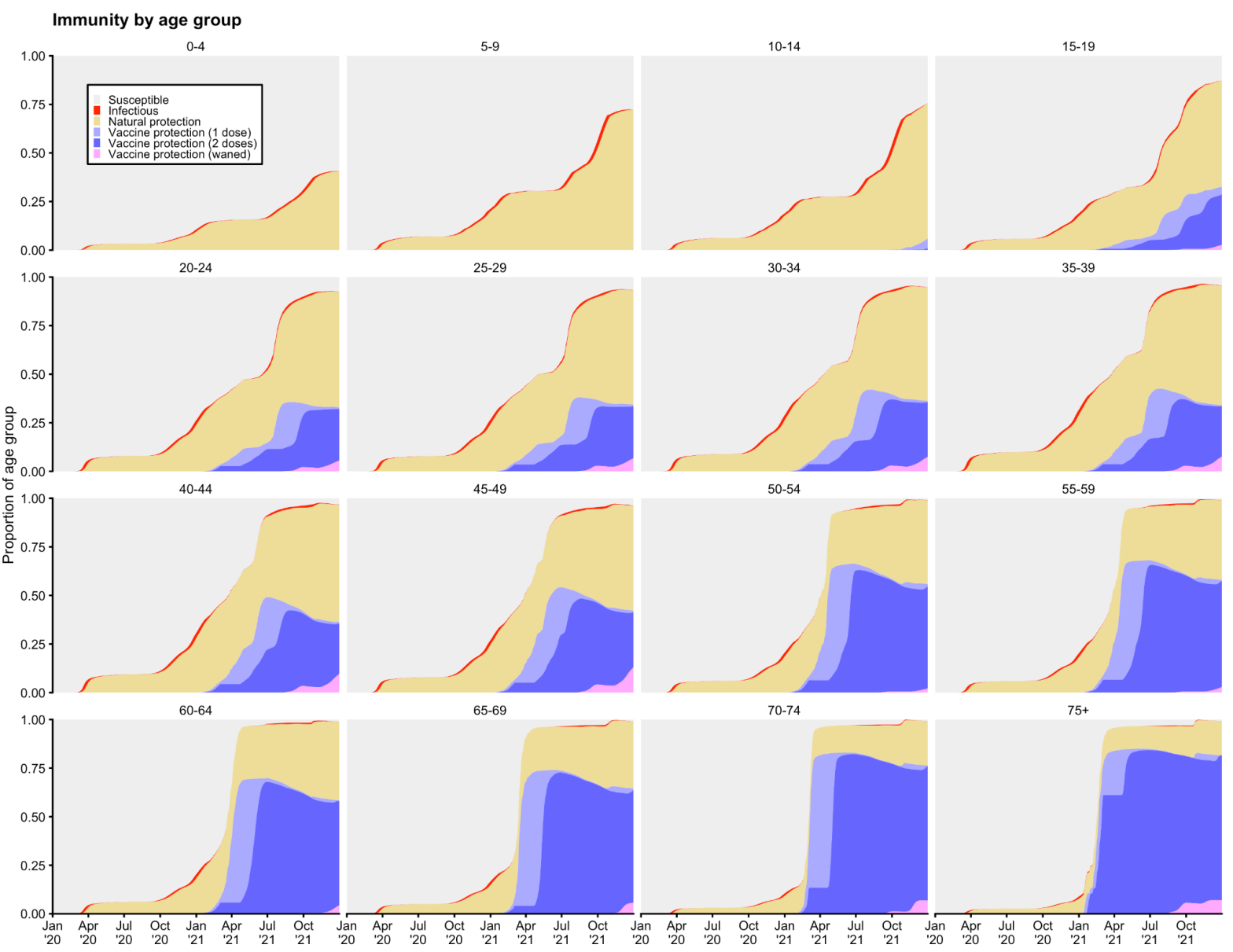

Figure S10. Distribution of natural and vaccine protection over time for each 5-year age group, amalgamated across England. Each panel shows the proportion of individuals in each age group who are: currently susceptible, currently infectious, naturally protected (including individuals who have been both vaccinated and have natural protection due to infection prior to or after vaccination), vaccine protected with 1 dose, vaccine protected with 2 doses, and partially vaccine protected with waned vaccine protection six months after the second dose. Note that, due to waning of both natural and vaccine protection back to the fully-susceptible state, the susceptible proportion does not represent the fraction of each age group that has never been infected or vaccinated, as it includes some people who have been infected or vaccinated but have completely lost their protection. The "base case" scenario (3-month return to baseline, $90 \%$ booster uptake among over-50s who have received their second dose, medium vaccine waning, $70 \%$ vaccine uptake in $12-15$-year-olds) is shown up to December 31, 2021. 
medRxiv preprint doi: https://doi.org/10.1101/2021.11.22.21266584; this version posted November 24,2021 . The copyright holder for this preprint (which was not certified by peer review) is the author/funder, who has granted medRxiv a license to display the preprint in It is made available under a CC-BY-NC-ND 4.0 International license.

Table S1 - Fitted model estimates for the relative transmissibility of Alpha B.1.1.7 variant (compared to pre-existing SARS-CoV-2 variants) and Delta B.1.617.2 (compared to Alpha), rounded to 2 decimal places.

\begin{tabular}{|l|l|l|}
\hline NHS England region & $\begin{array}{l}\text { Alpha relative } \\
\text { transmissibility }\end{array}$ & $\begin{array}{l}\text { Delta relative } \\
\text { transmissibility }\end{array}$ \\
\hline East of England & 1.65 & 1.59 \\
\hline London & 1.64 & 1.75 \\
\hline Midlands & 1.82 & 1.60 \\
\hline North East \& Yorkshire & 1.67 & 1.94 \\
\hline North West & 1.81 & 1.64 \\
\hline South East & 1.46 & 1.73 \\
\hline South West & 1.61 & 1.43 \\
\hline
\end{tabular}


medRxiv preprint doi: https://doi.org/10.1101/2021.11.22.21266584; this version posted November 24 , 2021. The copyright holder for this preprint (which was not certified by peer review) is the author/funder, who has granted medRxiv a license to display the preprint in It is made available under a CC-BY-NC-ND 4.0 International license.

Table S2 - Assumptions for vaccine effectiveness against all SARS-CoV-2 outcomes

\begin{tabular}{|c|c|c|c|c|c|}
\hline \multirow{3}{*}{ Outcome } & \multirow{3}{*}{ Variant name } & \multicolumn{4}{|c|}{ Vaccine effectiveness } \\
\hline & & \multicolumn{2}{|c|}{ Pfizer-BioNTech* } & \multicolumn{2}{|c|}{ Oxford-AstraZeneca } \\
\hline & & 1 dose & 2 doses & 1 dose & 2 doses \\
\hline \multirow[t]{2}{*}{ Infection } & pre-Alpha \& Alpha & $70 \%$ & $85 \%$ & $70 \%$ & $75 \%$ \\
\hline & Delta^ & $62 \%$ & $80 \%$ & $43 \%$ & $63 \%$ \\
\hline \multirow[t]{2}{*}{ Disease } & pre-Alpha \& Alpha & $70 \%$ & $90 \%$ & $70 \%$ & $80 \%$ \\
\hline & Delta^ $^{\wedge}$ & $62 \%$ & $81 \%$ & $52 \%$ & $65 \%$ \\
\hline \multirow[t]{2}{*}{ Hospitalisation } & pre-Alpha \& Alpha & $85 \%$ & $95 \%$ & $85 \%$ & $90 \%$ \\
\hline & Delta^ & $92 \%$ & $96 \%$ & $84 \%$ & $93 \%$ \\
\hline \multirow[t]{2}{*}{ Mortality } & pre-Alpha \& Alpha & $85 \%$ & $95 \%$ & $85 \%$ & $95 \%$ \\
\hline & Delta^ & $92 \%$ & $96 \%$ & $95 \%$ & $95 \%$ \\
\hline \multirow{2}{*}{$\begin{array}{l}\text { Onward } \\
\text { transmission }\end{array}$} & pre-Alpha \& Alpha & $47 \%$ & $47 \%$ & $47 \%$ & $47 \%$ \\
\hline & Delta^ & $24 \%$ & $37 \%$ & $5 \%$ & $27 \%$ \\
\hline \multicolumn{2}{|l|}{ Delay to efficacy } & 28 days & 14 days & 28 days & 14 days \\
\hline \multicolumn{6}{|c|}{$\begin{array}{l}\text { *We assume that the Moderna mRNA-1273 vaccine confers the same levels of protection as the } \\
\text { Pfizer-BioNTech vaccine. } \\
\text { ^For vaccine effectiveness with the Delta B.1.617.2 variant, we either scale the equivalent vaccine } \\
\text { effectiveness assumption for pre-Alpha and Alpha variants by the unweighted mean change in } \\
\text { protection from Alpha to Delta as measured by the references in Table S8, or assume equivalent } \\
\text { values from the previous equivalent dose or the previous level of protection. }\end{array}$} \\
\hline
\end{tabular}


medRxiv preprint doi: https://doi.org/10.1101/2021.11.22.21266584; this version posted November 24 , 2021. The copyright holder for this preprint (which was not certified by peer review) is the author/funder, who has granted medRxiv a license to display the preprint in It is made available under a CC-BY-NC-ND 4.0 International license .

Table S3 - Assumptions for 2-dose vaccine effectiveness against all SARS-CoV-2 outcomes and 2-dose + waned (i.e. no booster dose) scenarios. Values shown are rounded to the nearest whole percentage. Low waning uses measured percentage changes in vaccine protection over time from Andrews et al. ${ }^{12}$ to scale our existing assumptions on 2-dose protection (Table S2). Medium waning assumes a $25 \%$ reduction in the low waning values, and high waning assumes a $50 \%$ reduction in the low waning values.

\begin{tabular}{|c|c|c|c|c|c|}
\hline \multirow{3}{*}{ Outcome } & \multirow{3}{*}{ Variant name } & \multicolumn{4}{|c|}{ Vaccine effectiveness } \\
\hline & & \multicolumn{2}{|c|}{ Pfizer-BioNTech* } & \multicolumn{2}{|c|}{ Oxford-AstraZeneca } \\
\hline & & 2 doses & $\begin{array}{l}\text { Waning } \\
\text { scenario: low, } \\
\text { medium, high }\end{array}$ & 2 doses & $\begin{array}{l}\text { Waning } \\
\text { scenario: low, } \\
\text { medium, high }\end{array}$ \\
\hline \multirow[t]{2}{*}{ Infection } & pre-Alpha \& Alpha & $85 \%$ & $64 \%, 48 \%, 32 \%$ & $75 \%$ & $57 \%, 43 \%, 29 \%$ \\
\hline & Delta & $80 \%$ & $60 \%, 45 \%, 30 \%$ & $63 \%$ & $48 \%, 36 \%, 24 \%$ \\
\hline \multirow[t]{2}{*}{ Disease } & pre-Alpha \& Alpha & $90 \%$ & $68 \%, 51 \%, 34 \%$ & $80 \%$ & $60 \%, 45 \%, 30 \%$ \\
\hline & Delta & $81 \%$ & $61 \%, 46 \%, 31 \%$ & $65 \%$ & $49 \%, 37 \%, 25 \%$ \\
\hline \multirow[t]{2}{*}{ Hospitalisation } & pre-Alpha \& Alpha & $95 \%$ & $88 \%, 66 \%, 44 \%$ & $90 \%$ & $74 \%, 56 \%, 37 \%$ \\
\hline & Delta & $96 \%$ & $89 \%, 67 \%, 45 \%$ & $93 \%$ & $76 \%, 57 \%, 38 \%$ \\
\hline \multirow[t]{2}{*}{ Mortality } & pre-Alpha \& Alpha & $95 \%$ & $87 \%, 65 \%, 44 \%$ & $95 \%$ & $79 \%, 59 \%, 40 \%$ \\
\hline & Delta & $96 \%$ & $88 \%, 66 \%, 44 \%$ & $95 \%$ & $79 \%, 59 \%, 40 \%$ \\
\hline \multirow{2}{*}{$\begin{array}{l}\text { Onward } \\
\text { transmission }\end{array}$} & pre-Alpha \& Alpha & $47 \%$ & $40 \%, 30 \%, 20 \%$ & $47 \%$ & $38 \%, 29 \%, 19 \%$ \\
\hline & Delta & $37 \%$ & $32 \%, 24 \%, 16 \%$ & $27 \%$ & $22 \%, 17 \%, 11 \%$ \\
\hline
\end{tabular}


medRxiv preprint doi: https://doi.org/10.1101/2021.11.22.21266584; this version posted November 24 , 2021. The copyright holder for this preprint (which was not certified by peer review) is the author/funder, who has granted medRxiv a license to display the preprint in

It is made available under a CC-BY-NC-ND 4.0 International license .

Table S4 - Waning immunity scenarios

\begin{tabular}{|c|c|c|}
\hline Description & Assumed values (waning) & Vaccine \\
\hline Waning of natural immunity & $\begin{array}{l}\log (0.85) /-365, \text { corresponding to } 85 \% \\
\text { protection after } 365 \text { days }=1 \text { year }^{\wedge}\end{array}$ & \\
\hline $\begin{array}{l}\text { Waning of vaccine induced } \\
\text { immunity (second dose to } \\
\text { susceptible / naive) }\end{array}$ & 0 & \\
\hline $\begin{array}{l}\text { Waning of vaccine induced } \\
\text { immunity (first dose to } \\
\text { susceptible / naive and second } \\
\text { dose to first dose) }\end{array}$ & 0 & \\
\hline \multirow{2}{*}{$\begin{array}{l}\text { Waning of vaccine induced } \\
\text { immunity (second dose + } \\
\text { waned to susceptible / naive) }\end{array}$} & $\begin{array}{l}\log (0.93) /-140 \text {, corresponding to } 7 \% \text { loss } \\
\text { in protection after } 20 \text { weeks }{ }^{*}\end{array}$ & $\begin{array}{l}\text { Pfizer / } \\
\text { Moderna }\end{array}$ \\
\hline & $\begin{array}{l}\log (0.82) /-140 \text {, corresponding to } 18 \% \text { loss } \\
\text { in protection after } 20 \text { weeks }{ }^{*}\end{array}$ & AstraZeneca \\
\hline \multicolumn{3}{|c|}{$\begin{array}{l}\text { AWe referred to a number of studies looking at the level of protection against reinfection with } \\
\text { SARS-CoV- }{ }^{38} \text {. An unweighted mean across these studies finds approximately } 85.74 \% \\
\text { protection against reinfection with SARS-CoV- } 2 \text { after } 27.76 \text { weeks. When individuals in the } \\
\text { model who have been infected with SARS-CoV- } 2 \text { recover and then wane, they lose all } \\
\text { remaining protection against SARS-CoV- } 2 \text { outcomes of all types. We therefore assume that } \\
\text { the rate at which individuals lose all their protection is slower than that at which reinfections } \\
\text { might occur. } \\
\text { *We used vaccine-specific measured reductions in protection against hospitalisation over } 20 \\
\text { weeks from Andrews et al. }{ }^{12}\end{array}$} \\
\hline
\end{tabular}


medRxiv preprint doi: https://doi.org/10.1101/2021.11.22.21266584; this version posted November 24, 2021. The copyright holder for this preprint (which was not certified by peer review) is the author/funder, who has granted medRxiv a license to display the preprint in perpetuity.

It is made available under a CC-BY-NC-ND 4.0 International license

Table S5A - Details of fitted model parameters

\begin{tabular}{|c|c|c|c|}
\hline Parameter & Description & $\begin{array}{l}\text { Prior distribution or assumed } \\
\text { value / distribution }\end{array}$ & Notes \\
\hline tS & $\begin{array}{l}\text { Start date of wild-type } \\
\text { SARS-CoV- } 2 \text { epidemic } \\
\text { in days after } 1 \text { January } \\
2020\end{array}$ & $\begin{array}{l}\sim \text { uniform }(0,60) \text { (i.e. 1st January - } \\
\text { 1st March 2020) }\end{array}$ & $\begin{array}{l}\text { Determines the date at which seeding } \\
\text { begins in a region; starting on this date, } \\
\text { one random individual per day contracts } \\
\text { SARS-CoV-2, repeated for } 28 \text { days }\end{array}$ \\
\hline v2_when & $\begin{array}{l}\text { Start date of Alpha } \\
\text { B.1.1.7 SARS-CoV-2 } \\
\text { variant epidemic in } \\
\text { days after } 1 \text { January } \\
2020\end{array}$ & $\begin{array}{l}\text { uniform }(144,365) \\
\text { (i.e. 24th May - 31st December } \\
\text { 2020) }\end{array}$ & $\begin{array}{l}\text { Determines the date at which the novel } \\
\text { SARS-CoV-2 variant is introduced into a } \\
\text { region; on this date, ten random } \\
\text { individuals contract the Alpha B.1.1.7 } \\
\text { SARS-CoV-2 variant. }\end{array}$ \\
\hline v3_when & $\begin{array}{l}\text { Start date of Delta } \\
\text { B.1.617.2 SARS-CoV-2 } \\
\text { variant epidemic in } \\
\text { days after } 1 \text { January } \\
2020\end{array}$ & $\begin{array}{l}\text { uniform }(366,486) \\
\text { (i.e. } 1 \text { st January - 1st May 2021) }\end{array}$ & $\begin{array}{l}\text { Determines the date at which the novel } \\
\text { SARS-CoV-2 variant is introduced into a } \\
\text { region; on this date, ten random } \\
\text { individuals contract the Delta B.1.617.2 } \\
\text { SARS-CoV-2 variant. }\end{array}$ \\
\hline u & $\begin{array}{l}\text { Basic susceptibility to } \\
\text { infection }\end{array}$ & $\begin{array}{l}\sim \operatorname{normal}(0.09,0.02), \geq 0.04 \text { and } \\
\leq 0.2\end{array}$ & $\begin{array}{l}\text { Determines basic reproduction number } \\
\mathrm{R}_{0} \text {. }\end{array}$ \\
\hline v2_relu & $\begin{array}{l}\text { Relative transmissibility } \\
\text { of Alpha B.1.1.7 } \\
\text { variant, compared to } \\
\text { pre-existing variants }\end{array}$ & $\tilde{4}^{\text {lognormal }(0,0.4)}, \geq 0.25$ and $\leq$ & $\begin{array}{l}\text { Determines the transmission advantage } \\
\text { that the second SARS-CoV- } 2 \text { variant in } \\
\text { the model, parameterised for the Alpha } \\
\text { B.1.1.7 variant, has over pre-existing } \\
\text { variants. }\end{array}$ \\
\hline v3_relu & $\begin{array}{l}\text { Relative transmissibility } \\
\text { of Delta B.1.617.2 } \\
\text { variant, compared to } \\
\text { Alpha B.1.1.7 }\end{array}$ & $\underset{4}{\sim \operatorname{lognormal}(0,0.4), \geq 0.25 \text { and } \leq}$ & $\begin{array}{l}\text { Determines the transmission advantage } \\
\text { that the third SARS-CoV-2 variant in the } \\
\text { model, parameterised for the Delta } \\
\text { B.1.617.2 variant, has over the Alpha } \\
\text { B.1.1.7 variant. }\end{array}$ \\
\hline $\begin{array}{l}\text { v2_hosp_rlo } \\
\text { v2_icu_rlo } \\
\text { v2_cfr_rlo }\end{array}$ & $\begin{array}{l}\text { Relative log-odds of } \\
\text { hospitalisation, ICU } \\
\text { admission and death } \\
\text { for the Alpha B.1.1.7 } \\
\text { variant, compared to } \\
\text { pre-existing variants }\end{array}$ & $\sim \operatorname{normal}(0,0.1), \geq-4$ and $\leq 4$ & Vague priors \\
\hline v2_sgtfo & $\begin{array}{l}\text { The proportion of } \\
\text { wild-type SARS-CoV-2 } \\
\text { that produce S gene } \\
\text { target failure (i.e. the } \\
\text { "false positive" rate of } \\
\text { identifying Alpha } \\
\text { B.1.1.7 by SGTF } \\
\text { frequency) }\end{array}$ & $\sim \operatorname{beta}(1.5,15)$ & Vague prior \\
\hline v2_disp & $\begin{array}{l}\text { Controls variance in } \\
\text { the distribution for } \\
\text { fitting model-predicted } \\
\text { Alpha B.1.1.7 } \\
\text { frequency to SGTF } \\
\text { data }\end{array}$ & $\begin{array}{l}\sim \text { exponential }(10,10) \\
\geq 0 \text { and } \leq 0.25\end{array}$ & Vague prior \\
\hline death_mean & $\begin{array}{l}\text { Mean delay in days } \\
\text { from start of infectious } \\
\text { period to death }\end{array}$ & $\sim \operatorname{normal}(15,2), \geq 5$ and $\leq 30$ & $\begin{array}{l}\text { The delay itself is assumed to follow a } \\
\text { gamma distribution with shape } \\
\text { parameter } 2.2 \text {, and mean death mean. } \\
\text { Prior and shape of distribution informed } \\
\text { by analysis of CO-CIN data }{ }^{17} \text {. }\end{array}$ \\
\hline $\begin{array}{l}\text { hosp_admissio } \\
\text { n }\end{array}$ & $\begin{array}{l}\text { Mean delay in days } \\
\text { from start of infectious }\end{array}$ & $\sim \operatorname{normal}(8,1), \geq 4$ and $\leq 20$ & $\begin{array}{l}\text { Delay is assumed to follow a gamma } \\
\text { distribution with shape parameter } 0.71\end{array}$ \\
\hline
\end{tabular}


medRxiv preprint doi: https://doi.org/10.1101/2021.11.22.21266584; this version posted November 24, 2021. The copyright holder for this preprint (which was not certified by peer review) is the author/funder, who has granted medRxiv a license to display the preprint in perpetuity.

It is made available under a CC-BY-NC-ND 4.0 International license

\begin{tabular}{|c|c|c|c|}
\hline & $\begin{array}{l}\text { period to hospital } \\
\text { admission }\end{array}$ & & $\begin{array}{l}\text { and mean hosp_admission. Prior and } \\
\text { shape of distribution informed by } \\
\text { analysis of CO-CIN data }{ }^{17} \text {. }\end{array}$ \\
\hline icu_admission & $\begin{array}{l}\text { Mean delay in days } \\
\text { from start of infectious } \\
\text { period to ICU } \\
\text { admission }\end{array}$ & $\sim \operatorname{normal}(12.5,1), \geq 8$ and $\leq 14$ & $\begin{array}{l}\text { Delay is assumed to follow a gamma } \\
\text { distribution with shape parameter } 1.91 \\
\text { and mean icu_admission. Prior and } \\
\text { shape of distribution informed by } \\
\text { analysis of CO-CIN data }{ }^{17} \text {. }\end{array}$ \\
\hline $\begin{array}{l}f 102, f 144, \\
f 186, f 228, \\
f 270, f 312, \\
f 354, f 396, \\
f 438, f 480, \\
f 522, \\
f 606, f 648,\end{array}$ & $\begin{array}{l}\text { Contact multiplier for } \\
6 \text {-week consecutive } \\
\text { periods, starting from } \\
\text { 12th April } 2020 \text { (f102) - } \\
\text { 10th October } 2021 \\
\text { (f648). }\end{array}$ & $\sim \operatorname{lognormal}(0,0.1), \geq 0.5$ and $\leq 2$ & Vague prior \\
\hline
\end{tabular}

Table S5B. Model parameters not subject to fitting.

\begin{tabular}{|c|c|c|c|}
\hline Parameter & Description & Value & Reference \\
\hline$d_{E}$ & Latent period ( $E$ to $I_{P}$ and $E$ to $I_{S}$; days) & $\sim \operatorname{gamma}(\mu=2.5, k=2.5)$ & $\begin{array}{l}\text { Set to } 2.5 \text { so that } \\
\text { incubation period (latent } \\
\text { period plus period of } \\
\text { preclinical infectiousness) } \\
\text { is } 5 \text { days }{ }^{39}\end{array}$ \\
\hline$d_{P}$ & $\begin{array}{l}\text { Duration of preclinical infectiousness ( } I_{P} \\
\text { to } I_{C} ; \text { days) }\end{array}$ & $\sim \operatorname{gamma}(\mu=2.5, k=4)$ & $\begin{array}{l}\text { Assumed to be half the } \\
\text { duration of total } \\
\text { infectiousness in } \\
\text { clinically-infected } \\
\text { individuals }{ }^{40}\end{array}$ \\
\hline$d_{C}$ & $\begin{array}{l}\text { Duration of clinical infectiousness }\left(\mathrm{I}_{\mathrm{C}} \text { to }\right. \\
\mathrm{R} \text {; days) }\end{array}$ & $\sim \operatorname{gamma}(\mu=2.5, k=4)$ & $\begin{array}{l}\text { Infectious period set to } 5 \\
\text { days, to result in a serial } \\
\text { interval of approximately } 6 \\
\text { days }^{41-43}\end{array}$ \\
\hline$d_{s}$ & $\begin{array}{l}\text { Duration of subclinical infectiousness ( } I_{s} \\
\text { to } R ; \text { days) }\end{array}$ & $\sim \operatorname{gamma}(\mu=5 \cdot 0, k=4)$ & $\begin{array}{l}\text { Assumed to be the same } \\
\text { duration as total infectious } \\
\text { period for clinical cases, } \\
\text { including preclinical } \\
\text { transmission }\end{array}$ \\
\hline$y_{i}$ & $\begin{array}{l}\text { Probability of clinical symptoms given } \\
\text { infection for age group } i\end{array}$ & $\begin{array}{l}\text { Estimated from case } \\
\text { distributions across } 6 \\
\text { countries }\end{array}$ & 23 \\
\hline$f$ & $\begin{array}{l}\text { Relative infectiousness of subclinical } \\
\text { cases }\end{array}$ & $50 \%$ & Assumed ${ }^{23,44}$ \\
\hline$c_{i j}$ & $\begin{array}{l}\text { Number of age- } j \text { individuals contacted by } \\
\text { an age- } i \text { individual per day, prior to } \\
\text { changes in mobility }\end{array}$ & UK-specific contact matrix & 45 \\
\hline$N_{i}$ & Number of age- $i$ individuals & From demographic data & 46 \\
\hline$\Delta t$ & Time step for discrete-time simulation & 0.25 days & \\
\hline$P(I C U)_{i}$ & $\begin{array}{l}\text { Proportion of hospitalised cases that } \\
\text { require critical care for age group } i\end{array}$ & $\begin{array}{l}\text { Estimated from CO-CIN } \\
\text { data }\end{array}$ & 47 \\
\hline
\end{tabular}


medRxiv preprint doi: https://doi.org/10.1101/2021.11.22.21266584; this version posted November 24, 2021. The copyright holder for this preprint (which was not certified by peer review) is the author/funder, who has granted medRxiv a license to display the preprint in perpetuity.

It is made available under a CC-BY-NC-ND 4.0 International license .

Table S6 - List of scenarios and key assumptions. Scenarios are listed in the same order as Figure 4. Scenarios marked with an asterisk $\left({ }^{*}\right)$ and a caret $\left({ }^{\wedge}\right)$ are equivalent. For the public health and social measures (PHSMs) scenarios, details related to each specific measure or combination of measures considered are given in the online Methods section. For the vaccine scenarios considering vaccination of children of different age ranges and coverage levels, a unique vaccine schedule was generated for each scenario, according to the specified age range and coverage levels, as described in the online Methods section.

\begin{tabular}{|c|c|c|c|c|c|}
\hline Scenario name & Result type & Mobility & Waning & Boosters & Seasonality \\
\hline Basecase* $^{*}$ & - & 6-month & Medium & $50+, 90 \%$ & $20 \%$ \\
\hline No relaxation & Behaviour & No change & Medium & $50+, 90 \%$ & $20 \%$ \\
\hline 3-month relaxation & Behaviour & 3-month & Medium & $50+, 90 \%$ & $20 \%$ \\
\hline 6-month relaxation* & Behaviour & 6-month & Medium & $50+, 90 \%$ & $20 \%$ \\
\hline No boosters & Boosters & 6-month & Medium & No boosters & $20 \%$ \\
\hline Boosters in $50+^{*}$ & Boosters & 6-month & Medium & $50+, 90 \%$ & $20 \%$ \\
\hline Boosters in $40+$ & Boosters & 6-month & Medium & $40+, 90 \%$ & $20 \%$ \\
\hline Boosters in $30+$ & Boosters & 6-month & Medium & $30+, 90 \%$ & $20 \%$ \\
\hline Boosters for all & Boosters & 6-month & Medium & $12+, 90 \%$ & $20 \%$ \\
\hline Low waning & Waning & 6-month & Low & $50+, 90 \%$ & $20 \%$ \\
\hline Medium waning* & Waning & 6-month & Medium & $50+, 90 \%$ & $20 \%$ \\
\hline High waning^ & Waning & 6-month & High & $50+, 90 \%$ & $20 \%$ \\
\hline No PHSMs^ & PHSMs & 6-month & High & $50+, 90 \%$ & $20 \%$ \\
\hline PHSMs: Certification & PHSMs & 6-month & High & $50+, 90 \%$ & $20 \%$ \\
\hline PHSMs: Face coverings & PHSMs & 6-month & High & $50+, 90 \%$ & $20 \%$ \\
\hline PHSMs: Work from home & PHSMs & 6-month & High & $50+, 90 \%$ & $20 \%$ \\
\hline PHSMs: All measures & PHSMs & 6-month & High & $50+, 90 \%$ & $20 \%$ \\
\hline $10 \%$ seasonality & Seasonality & 6-month & Medium & $50+, 90 \%$ & $10 \%$ \\
\hline $20 \%$ seasonality* & Seasonality & 6-month & Medium & $50+, 90 \%$ & $20 \%$ \\
\hline $30 \%$ seasonality & Seasonality & 6-month & Medium & $50+, 90 \%$ & $30 \%$ \\
\hline $40 \%$ seasonality & Seasonality & 6-month & Medium & $50+, 90 \%$ & $40 \%$ \\
\hline $12+, 50 \%$ uptake & Vaccines & 6-month & Medium & $50+, 90 \%$ & $20 \%$ \\
\hline $12+, 70 \%$ uptake* & Vaccines & 6-month & Medium & $50+, 90 \%$ & $20 \%$ \\
\hline $5+, 70 \%$ uptake & Vaccines & 6-month & Medium & $50+, 90 \%$ & $20 \%$ \\
\hline $5+, 50 \%$ uptake & Vaccines & 6-month & Medium & $50+, 90 \%$ & $20 \%$ \\
\hline
\end{tabular}


medRxiv preprint doi: https://doi.org/10.1101/2021.11.22.21266584; this version posted November 24, 2021. The copyright holder for this preprint (which was not certified by peer review) is the author/funder, who has granted medRxiv a license to display the preprint in It is made available under a CC-BY-NC-ND 4.0 International license .

Table S7 - Vaccine effectiveness against pre-B.1.1.7 and Alpha B.1.1.7 variants relevant evidence and baseline model assumptions

\begin{tabular}{|c|c|}
\hline Description & Relevant evidence, assumed value shown in bold \\
\hline $\begin{array}{l}\text { Overall protection against } \\
\text { infection for AstraZeneca } \\
\text { dose } 1\end{array}$ & $\begin{array}{l}\text { Shrotri et al. Table } 4 \text { adjusted hazard ratio } 0.33(0.16,0.68) \text { at } \\
28-34 \text { days post vaccination for protection against infection in } \\
\text { care home residents. Pritchard et al., supplementary } \\
\text { information, Table } 6 \text {, adjusted odds ratio }>=21 \text { days after first } \\
\text { dose of AZ, no second dose, } 0.39(0.32,0.46) \text { for all positives. } \\
\text { Glampson et al. results, Table } 2 \text {, hazard ratio } 0.26(0.19,0.35) \\
\text { for AZ between } 22 \text { and } 28 \text { days following first dose when } \\
\text { comparing AZ vaccinated individuals with unvaccinated } \\
\text { individuals. Thus a } 74 \% \text { reduction in risk of testing positive for } \\
\text { COVID-19. Amirthalingam et al. results, adults aged } 80 \text { and } \\
\text { above, } 43 \% \text { vaccine protection ( } 24-58 \%) \text { on days } 28-34 \\
\text { following the first dose of AZ. Amongst } 65-79 \text { year olds } 55 \% \\
\text { vaccine protection ( } 48-61 \%) 28 \text { days after the first dose of AZ. } \\
\text { Amongst } 50-64 \text { year olds } 50 \% \text { vaccine protection ( } 45-55 \%) 28 \\
\text { days after the first dose of AZ. Evidence of reductions in } \\
\text { vaccine protection by } 70 \text { days post vaccination: } 40 \%(23-53 \%) \\
\text { and } 26 \% \text { (18-33\%) for } 65-79 \text { and } 50-64 \text { year olds respectively. } \\
\text { Point estimates showed a decline after } 8 \text { weeks for individuals } \\
\text { aged } 80 \text { and above (but wide confidence intervals). Pouwels } \\
\text { et al. report vaccine effectiveness against all PCR-confirmed } \\
\text { infections with the Alpha variant of } 63 \% \text { (55-69\%) at least } 21 \\
\text { days following the first dose of AZ. Sheikh et al. report vaccine } \\
\text { effectiveness against PCR-confirmed infection (regardless of } \\
\text { symptom status) of } 37 \% \text { (32-42\%) } 28 \text { days after the first dose } \\
\text { of AZ. } \\
0.7 \text { ( }+28 \text { days) }\end{array}$ \\
\hline $\begin{array}{l}\text { Overall protection against } \\
\text { disease for AstraZeneca } \\
\text { dose } 1\end{array}$ & $\begin{array}{l}\text { Pritchard et al., supplementary information, Table } 6 \text {, adjusted } \\
\text { odds ratio }>=21 \text { days after first dose of AZ, no second dose, } \\
0.29(0.22,0.38) \text { for positive individuals with symptoms } \\
\text { reported. Lopez Bernal et al. (cohort aged } 70+\text { years of age) } \\
\text { Table 3, ChAdOx } 1 \text { adjusted odds ratio d1:28-34 } 0.4 \\
(0.27-0.59) \text {. PHE's week } 20 \text { vaccine surveillance reports } \\
\text { reports estimates of } 53 \%(49-57 \%) \text { vaccine protection against } \\
\text { symptomatic disease at least } 28 \text { days following the first dose } \\
\text { of AZ (compared to unvaccinated individuals). Compared to } \\
\text { individuals between } 4 \text { and } 13 \text { days after the first dose, they } \\
\text { estimate } 58 \% \text { (54-62\%) protection against symptomatic } \\
\text { disease. Whitaker et al. Table } 4 \text {, adjusted vaccine } \\
\text { effectiveness against symptomatic COVID-19 } 28-90 \text { days post } \\
\text { first dose of AZ } 50.2 \%(40.8-58.2 \%) \text { for individuals aged } 16-64 \\
\text { and } 60.9 \% \text { (49.0-70.0\%) for individuals aged } 65 \text { and over. } \\
\text { Lopez Bernal et al. C report adjusted vaccine effectiveness } \\
\text { against symptomatic infection with S-gene target negatives } \\
\text { (i.e. Alpha variant) of } 48.7 \% \text { (45.2\% to } 51.9 \%) \text {. Pouwels et al. }\end{array}$ \\
\hline
\end{tabular}


medRxiv preprint doi: https://doi.org/10.1101/2021.11.22.21266584; this version posted November 24, 2021. The copyright holder for this preprint (which was not certified by peer review) is the author/funder, who has granted medRxiv a license to display the preprint in

It is made available under a CC-BY-NC-ND 4.0 International license .

\begin{tabular}{|c|c|}
\hline & 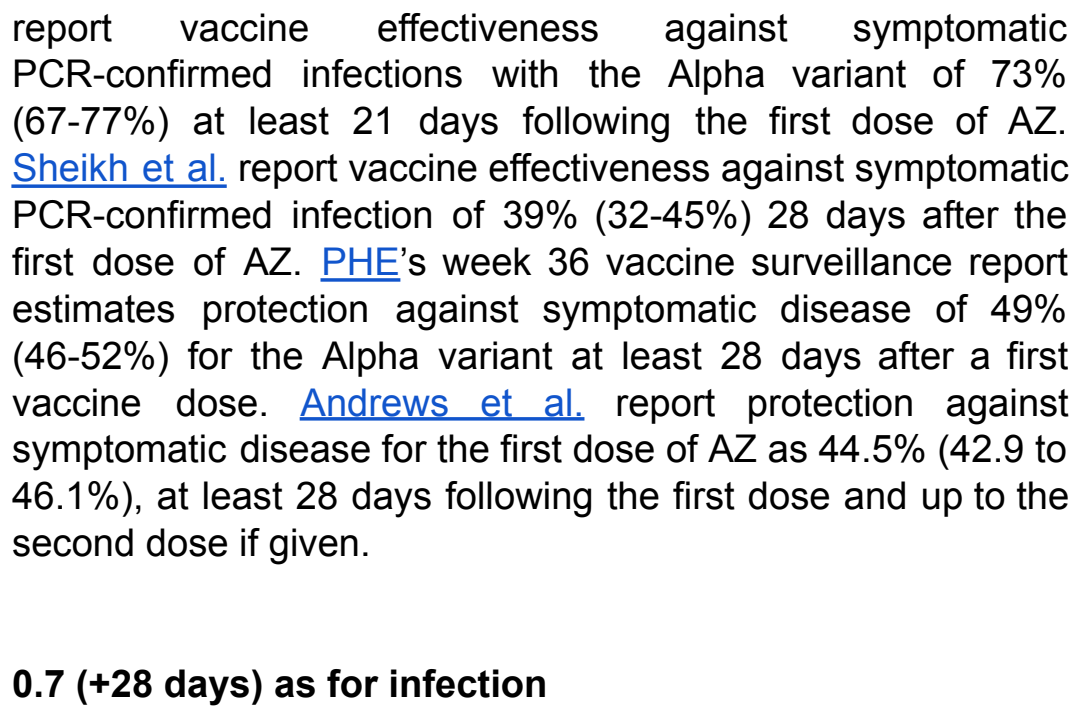 \\
\hline $\begin{array}{l}\text { Overall protection against } \\
\text { hospitalisation for } \\
\text { AstraZeneca dose } 1\end{array}$ & 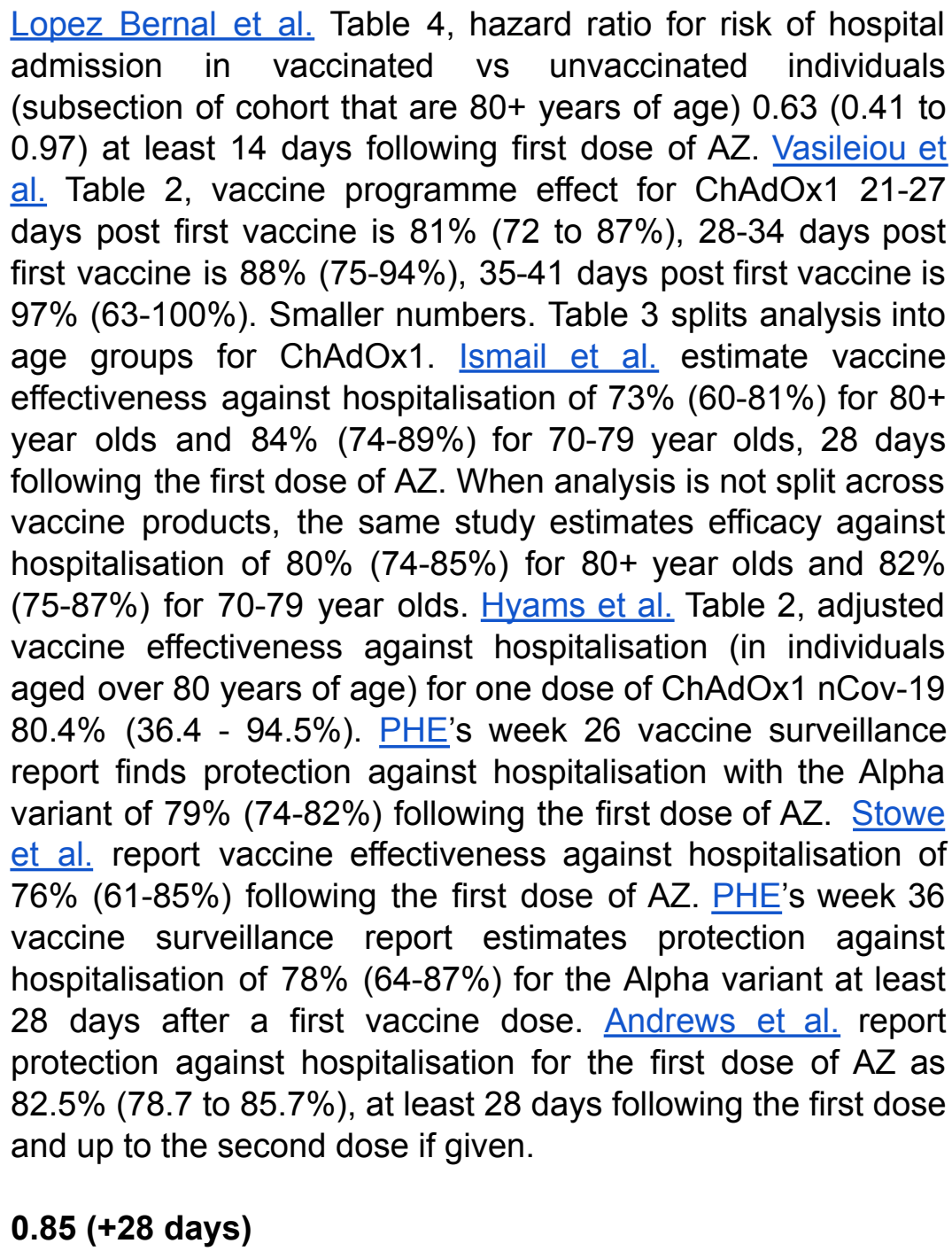 \\
\hline $\begin{array}{l}\text { Overall protection against } \\
\text { mortality for AstraZeneca } \\
\text { dose } 1\end{array}$ & $\begin{array}{l}\text { Lopez Bernal et al. B (study in a care home population) } \\
\text { estimated a hazard ratio of } 0.45(0.34-0.59) \text { for cases } \\
\text { vaccinated with one dose of } A Z \text { compared to unvaccinated }\end{array}$ \\
\hline
\end{tabular}




\begin{tabular}{|c|c|}
\hline & $\begin{array}{l}\text { cases, indicating an additional } 55 \%(41-66 \%) \text { protection } \\
\text { against death given becoming a case for individuals } \\
\text { vaccinated with one dose of AZ. Using the aforementioned } \\
\text { estimate of a } 55 \% \text { increase and assuming this in addition to } \\
\text { protection against disease of } 0.7 \text {, we get overall protection } \\
\text { against mortality of } 86.5 \% \text {. PHE's week } 26 \text { vaccine } \\
\text { surveillance report finds protection against mortality with the } \\
\text { Alpha variant of } 79 \% \text { ( } 73-83 \%) \text { and } 83 \%(78-86 \%) \text { for } 40-64 \\
\text { and } 65+\text { year olds respectively, following the first dose of AZ. } \\
\text { Andrews et al. report protection against death for the first dose } \\
\text { of AZ as } 79.1 \% \text { ( } 68.8 \text { to } 86 \%) \text {, at least } 28 \text { days following the } \\
\text { first dose and up to the second dose if given. } \\
\mathbf{0 . 8 5 ~ ( + 2 8 ~ d a y s ) ~}\end{array}$ \\
\hline $\begin{array}{l}\text { Overall protection against } \\
\text { onward transmission for } \\
\text { AstraZeneca dose } 1\end{array}$ & 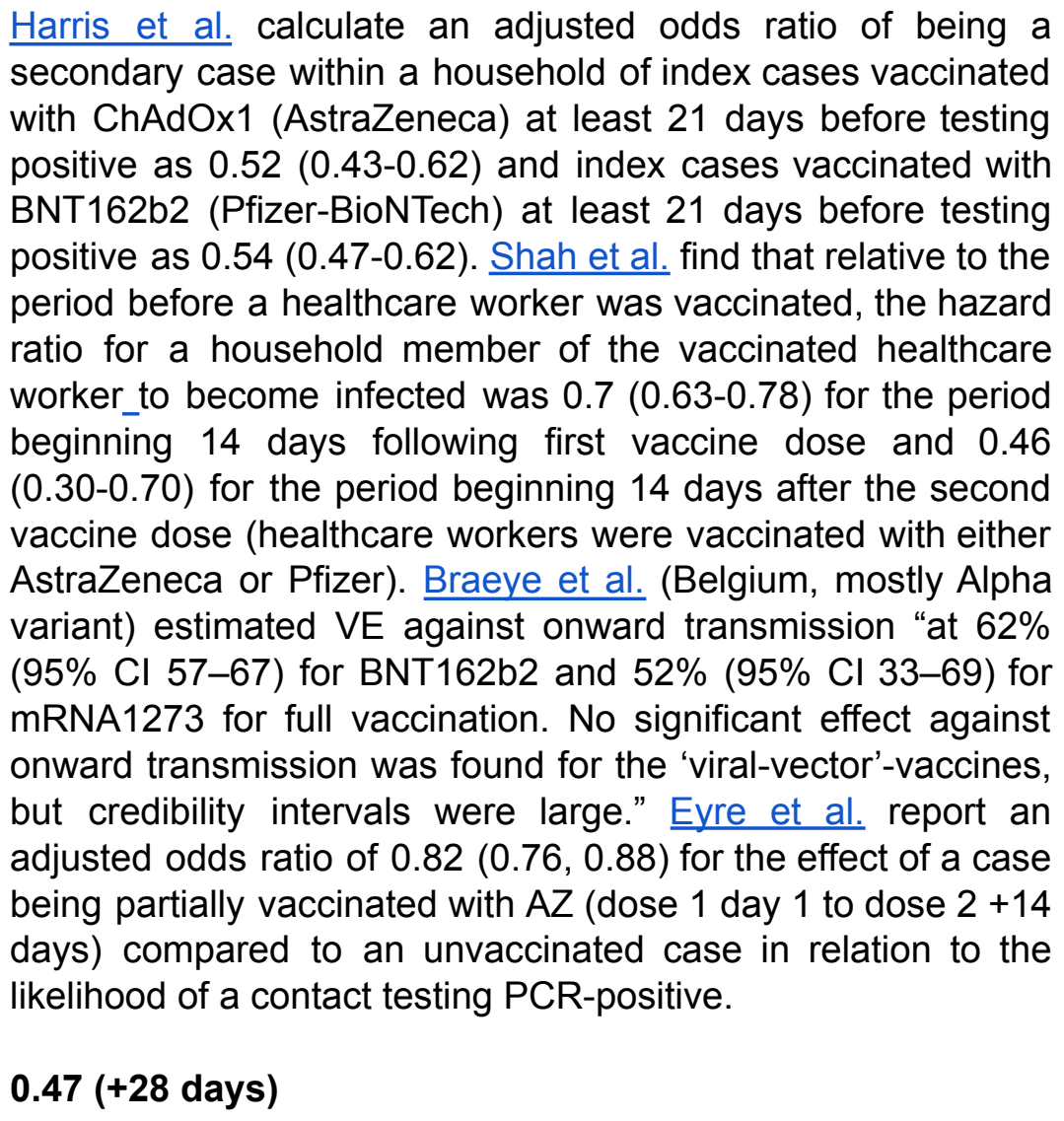 \\
\hline $\begin{array}{l}\text { Overall protection against } \\
\text { infection for AstraZeneca } \\
\text { dose } 2\end{array}$ & $\begin{array}{l}\text { Shrotri et al. Table } 4 \text { adjusted hazard ratio } 0.32(0.15,0.66) \text { at } \\
35-48 \text { days post vaccination in care home residents. Pritchard } \\
\text { et al., supplementary information, Table } 6 \text {, adjusted odds ratio } \\
\text { post second dose of AZ } 0.21(0.12,0.35) \text { for all positives. } \\
\text { Lopez Bernal et al. (cohort aged } 70+\text { years of age) Table } 3 \text {, } \\
\text { ChAdOx } 1 \text { adjusted odds ratio d } 1:>=35 \text { days } 0.27(0.10 \text { to } \\
0.73) \text {. Amirthalingam et al. results, individuals aged } 80+\text { years } \\
\text { old had } 96 \%(68-99 \%) \text { and } 82 \%(68-89 \%) \text { vaccine effect at } \\
\text { least } 14 \text { days following the second dose of AZ with } 45-64 \text { and }\end{array}$ \\
\hline
\end{tabular}


medRxiv preprint doi: https://doi.org/10.1101/2021.11.22.21266584; this version posted November 24 , 2021. The copyright holder for this preprint (which was not certified by peer review) is the author/funder, who has granted medRxiv a license to display the preprint in

It is made available under a CC-BY-NC-ND 4.0 International license .

\begin{tabular}{|c|c|}
\hline & $\begin{array}{l}65-84 \text { day intervals between first and second doses. "Those } \\
\text { receiving their second dose outside of these recommended } \\
\text { intervals also had high VE after two doses; for an } \geq 85 \text { day } \\
\text { interval, the estimated VE was } 88 \% \text { ( } 95 \% \text { Cl: } 48-97) \text { )" Pouwels } \\
\text { et al. report vaccine effectiveness against all PCR-confirmed } \\
\text { infections with the Alpha variant of } 79 \%(56-90 \%) \text { at least } 14 \\
\text { days following the second dose of AZ. Sheikh et al. report } \\
\text { vaccine effectiveness against PCR-confirmed infection } \\
\text { (regardless of symptom status) of } 73 \%(66-78 \%) 14 \text { days after } \\
\text { the second dose of AZ. } \\
\mathbf{0 . 7 5 ~ ( + 1 4 ~ d a y s ) ~}\end{array}$ \\
\hline $\begin{array}{l}\text { Overall protection against } \\
\text { disease for AstraZeneca } \\
\text { dose } 2\end{array}$ & 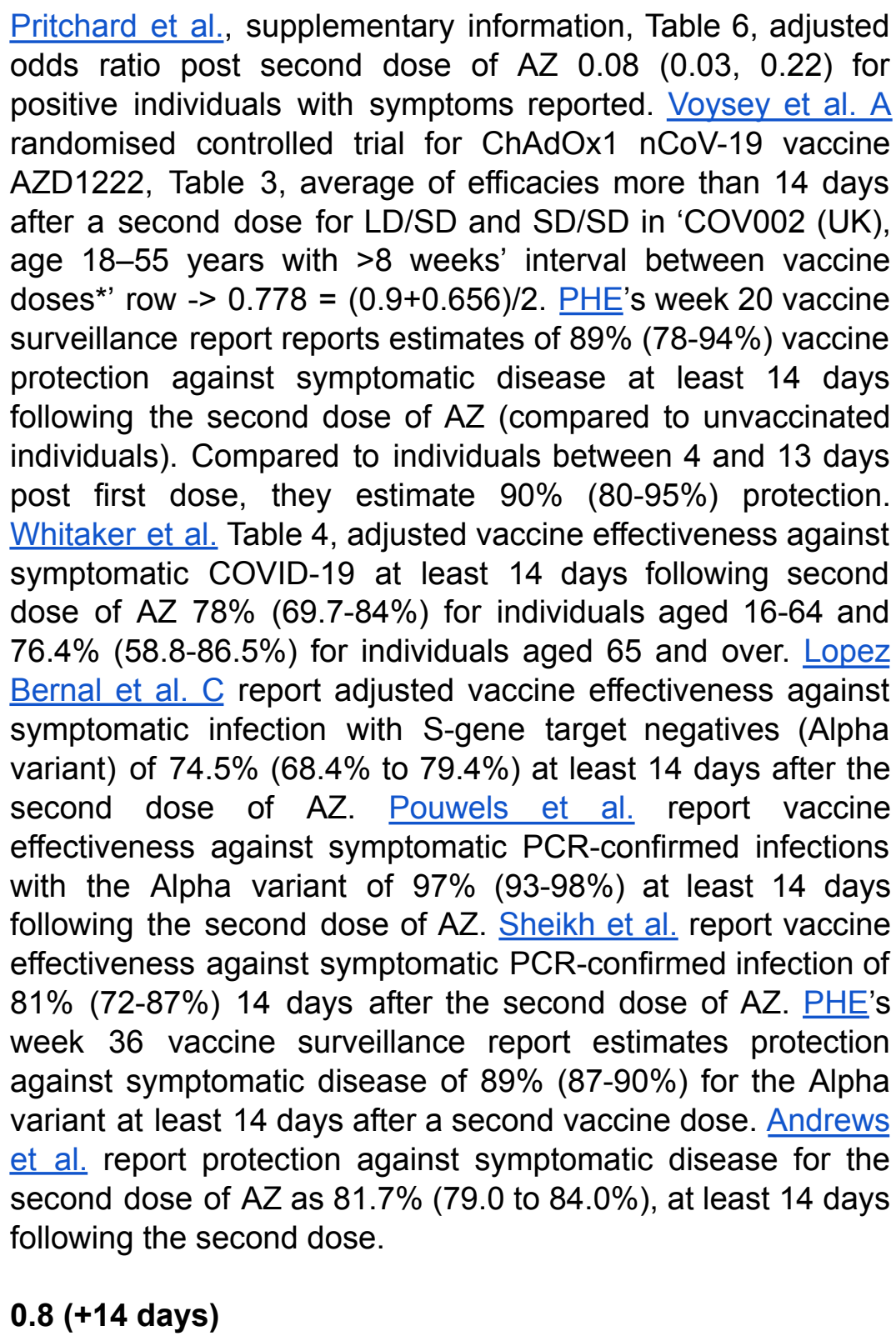 \\
\hline $\begin{array}{l}\text { Overall protection against } \\
\text { hospitalisation for } \\
\text { AstraZeneca dose } 2\end{array}$ & $\begin{array}{l}\text { Ismail et al. estimate vaccine effectiveness against } \\
\text { hospitalisation of } 92 \%(87-95 \%) 14 \text { days after a second dose } \\
\text { across both } A Z \text { and Pfizer vaccines. PHE's week } 26 \text { vaccine }\end{array}$ \\
\hline
\end{tabular}


medRxiv preprint doi: https://doi.org/10.1101/2021.11.22.21266584; this version posted November 24, 2021. The copyright holder for this preprint (which was not certified by peer review) is the author/funder, who has granted medRxiv a license to display the preprint in

\begin{tabular}{|c|c|}
\hline & $\begin{array}{l}\text { surveillance report finds protection against hospitalisation with } \\
\text { the Alpha variant of } 94 \% \text { ( } 81-98) \text { following the second dose of } \\
\text { AZ. Stowe et al. report vaccine effectiveness against } \\
\text { hospitalisation of } 86 \%(53-96 \%) \text { following the second dose of } \\
\text { AZ. PHE's week } 36 \text { vaccine surveillance report estimates } \\
\text { protection against hospitalisation of } 93 \%(80-97 \%) \text { for the } \\
\text { Alpha variant at least } 14 \text { days after a second vaccine dose. } \\
\text { Andrews et al. report protection against hospitalisation for the } \\
\text { second dose of AZ as } 93.9 \% \text { ( } 84.9 \text { to } 97.5 \%) \text {, at least } 14 \text { days } \\
\text { following the second dose. } \\
\mathbf{0 . 9} \text { (+14 days) }\end{array}$ \\
\hline $\begin{array}{l}\text { Overall protection against } \\
\text { mortality for AstraZeneca } \\
\text { dose } 2\end{array}$ & $\begin{array}{l}\text { PHE's week } 26 \text { vaccine surveillance report finds protection } \\
\text { against mortality with the Alpha variant of } 92 \%(76-98 \%) \text { and } \\
94 \%(80-98 \%) \text { for } 40-64 \text { and } 65+\text { year olds respectively, } \\
\text { following the second dose of } A Z \text {. Andrews et al. report } \\
\text { protection against death for the second dose of } A Z \text { as } 100 \% \text { at } \\
\text { least } 14 \text { days following the second dose. } \\
\mathbf{0 . 9 5} \text { (+14 days) }\end{array}$ \\
\hline $\begin{array}{l}\text { Overall protection against } \\
\text { onward transmission for } \\
\text { AstraZeneca dose } 2\end{array}$ & $\begin{array}{l}\text { Shah et al. find that relative to the period before a healthcare } \\
\text { worker was vaccinated, the hazard ratio for a household } \\
\text { member of the vaccinated healthcare worker to become } \\
\text { infected was } 0.7(0.63-0.78) \text { for the period beginning } 14 \text { days } \\
\text { following first vaccine dose and } 0.46(0.30-0.70) \text { for the period } \\
\text { beginning } 14 \text { days after the second vaccine dose (healthcare } \\
\text { workers were vaccinated with either AstraZeneca or Pfizer). } \\
\text { Braeye et al. (Belgium, mostly Alpha variant) estimated VE } \\
\text { against onward transmission "at } 62 \% \text { ( } 95 \% \mathrm{Cl} 57-67) \text { for } \\
\text { BNT162b2 and } 52 \% \text { ( } 95 \% \mathrm{Cl} 33-69) \text { for mRNA1273 for full } \\
\text { vaccination. No significant effect against onward transmission } \\
\text { was found for the 'viral-vector'-vaccines, but credibility } \\
\text { intervals were large." Eyre et al. report an adjusted odds ratio } \\
\text { of } 0.37 \text { ( } 0.22 \text {, } 0.63) \text { for the effect of a case being fully } \\
\text { vaccinated with AZ (dose } 2 \text { +14 days) compared to an } \\
\text { unvaccinated case in relation to the likelihood of a contact } \\
\text { testing PCR-positive. } \\
0.47 \text { (+14 days) }\end{array}$ \\
\hline $\begin{array}{l}\text { Overall protection against } \\
\text { infection for Pfizer dose } 1\end{array}$ & $\begin{array}{l}\text { Hall et al. Table } 2 \text {, full cohort adjusted hazard ratio d1>=21 } \\
\text { days } 0.30 \quad(0.15-0.45) \text {. Pritchard et al. supplementary } \\
\text { information, Table } 6 \text {, adjusted odds ratio }>=21 \text { days after first } \\
\text { dose of Pfizer, no second dose, } 0.34(0.29,0.40) \text { for all } \\
\text { positives. Shrotri et al. Table } 4 \text { adjusted hazard ratio } 0.47 \\
(0.20,1.06) \text { at } 28-34 \text { days post vaccination for protection } \\
\text { against infection in care home residents. Glampson et al. } \\
\text { results, Table } 2 \text {, hazard ratio } 0.22(0.18,0.27) \text { for Pfizer }\end{array}$ \\
\hline
\end{tabular}




\begin{tabular}{|c|c|}
\hline & $\begin{array}{l}\text { between } 22 \text { and } 28 \text { days following first dose when comparing } \\
\text { Pfizer vaccinated individuals with unvaccinated individuals. } \\
\text { Thus a } 78 \% \text { reduction in risk of testing positive for COVID-19. } \\
\text { Mason et al. Table } 2 \text {, vaccine effect of } 55.2 \%(40.8-66.8 \%) \\
21-27 \text { days post first dose, of } 53.7 \%(35.4-66.6 \%) 28-34 \\
\text { days post first dose and of } 70.1 \% \text { (55.1-80.1\%) } 35-41 \text { days } \\
\text { post first dose in individuals aged } 80-83 \text { years of age. } \\
\text { Azamgarhi et al. Table } 2,14 \text { days after first vaccination dose } \\
\text { in healthcare workers find an adjusted hazard ratio of } 0.3 \\
\text { (0.09,0.94) for protection against documented infection. } \\
\text { Amirthalingam et al. results, } 80+\text { year olds had } 61 \% \text { (49-71\%) } \\
\text { vaccine protection with a } 3 \text {-week dosing schedule at } 28-34 \\
\text { days post first dose of Pfizer. } 80+\text { year olds with the longer } \\
\text { dosing interval had } 52 \% \text { (39-63\%) vaccine protection } 28-34 \\
\text { days following the first dose of Pfizer. "Amongst } 65-79 \\
\text { year-olds, VE began to increase from } 10-13 \text { days after } \\
\text { vaccination, reaching } 53 \% \text { (95\%Cl: } 45-60) \text { on days } 28-34 \text {, and } \\
\text { remained at a similar level between } 35-69 \text { days (5-10 weeks). } \\
\text { A similar trend was observed in the BNT162b2 recipients aged } \\
50-64 \text { years with a VE of } 58 \% \text { at days } 28-34 \text {. Whilst there was } \\
\text { some evidence of a } 10-20 \% \text { decrease in VE by } 10 \text { weeks after } \\
\text { the first dose, there was an apparent rise again in VE at the } \\
\text { final interval, although with wide confidence intervals". } \\
\text { Pouwels et al. report vaccine effectiveness against all } \\
\text { PCR-confirmed infections with the Alpha variant of } 59 \% \\
\text { (52-65\%) at least } 21 \text { days following the first dose of Pfizer. } \\
\text { Sheikh et al. report vaccine effectiveness against } \\
\text { PCR-confirmed infection (regardless of symptom status) of } \\
38 \% \text { ( } 29-45 \% \text { ) } 28 \text { days after the first dose of Pfizer. } \\
\text { 0.7 (+28 days) }\end{array}$ \\
\hline $\begin{array}{l}\text { Overall protection against } \\
\text { disease for Pfizer dose } 1\end{array}$ & $\begin{array}{l}\text { Lopez Bernal et al. (cohort aged } 70+\text { years of age) Table } 2 \text {, } \\
\text { odds ratio vs day } 4-9 \text {, d1:28-34 } 0.30(0.22-0.41) \text {. Pritchard et } \\
\text { al., supplementary information, Table } 6 \text {, adjusted odds ratio }>= \\
21 \text { days after first dose of Pfizer, no second dose, } 0.22(0.17 \text {, } \\
0.28) \text { for positive individuals with symptoms reported. PHE's } \\
\text { week } 20 \text { vaccine surveillance report estimates protection } \\
\text { against symptomatic disease at least } 28 \text { days following the } \\
\text { first dose of Pfizer as } 54 \%(50-58 \%) \text { compared to } \\
\text { unvaccinated individuals. Compared to individuals between } 4 \\
\text { and } 13 \text { days post first dose, they estimate } 57 \% \text { (53-61\%) } \\
\text { protection. Whitaker et al. Table } 4 \text {, adjusted vaccine } \\
\text { effectiveness against symptomatic COVID-19 } 28-90 \text { days post } \\
\text { first dose of Pfizer } 48.6 \% \text { (27.9-63.3\%) for individuals aged } \\
16-64 \text { and } 56.6 \% \text { ( } 47.6-64.1 \%) \text { for individuals aged } 65 \text { and } \\
\text { over. Lopez Bernal et al. C report adjusted vaccine } \\
\text { effectiveness against symptomatic infection with S-gene target } \\
\text { negatives (i.e. Alpha variant) of } 47.5 \% \text { (41.6\% to } 52.8 \%) \text {. } \\
\text { Pouwels et al. report vaccine effectiveness against }\end{array}$ \\
\hline
\end{tabular}


medRxiv preprint doi: https://doi.org/10.1101/2021.11.22.21266584; this version posted November 24,2021 . The copyright holder for this preprint (which was not certified by peer review) is the author/funder, who has granted medRxiv a license to display the preprint in

It is made available under a CC-BY-NC-ND 4.0 International license .

\begin{tabular}{|c|c|}
\hline & 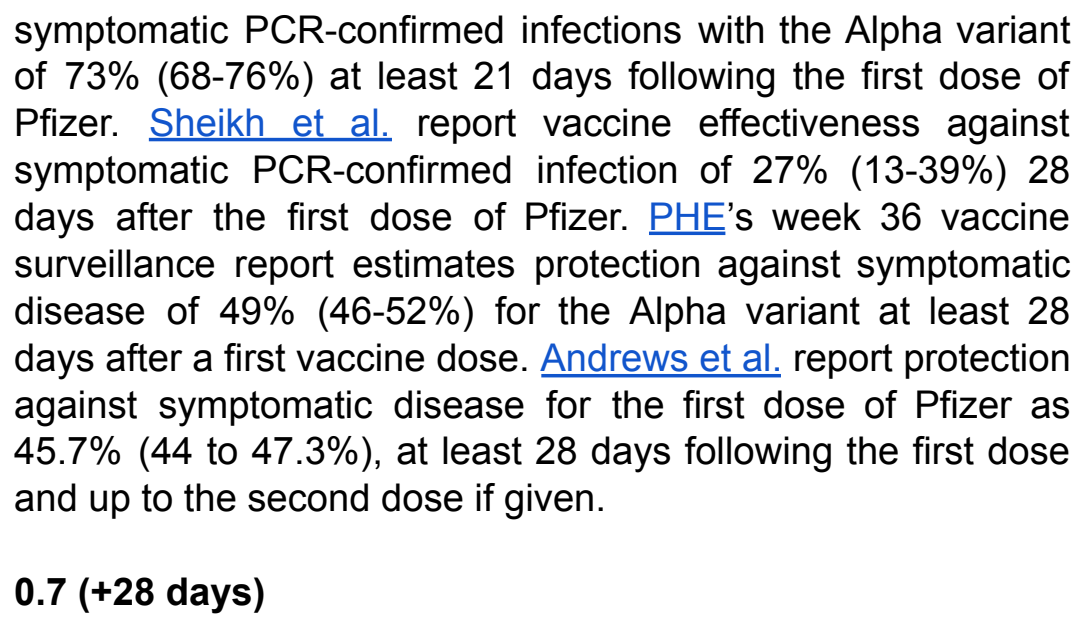 \\
\hline $\begin{array}{l}\text { Overall protection against } \\
\text { hospitalisation for Pfizer } \\
\text { dose } 1\end{array}$ & 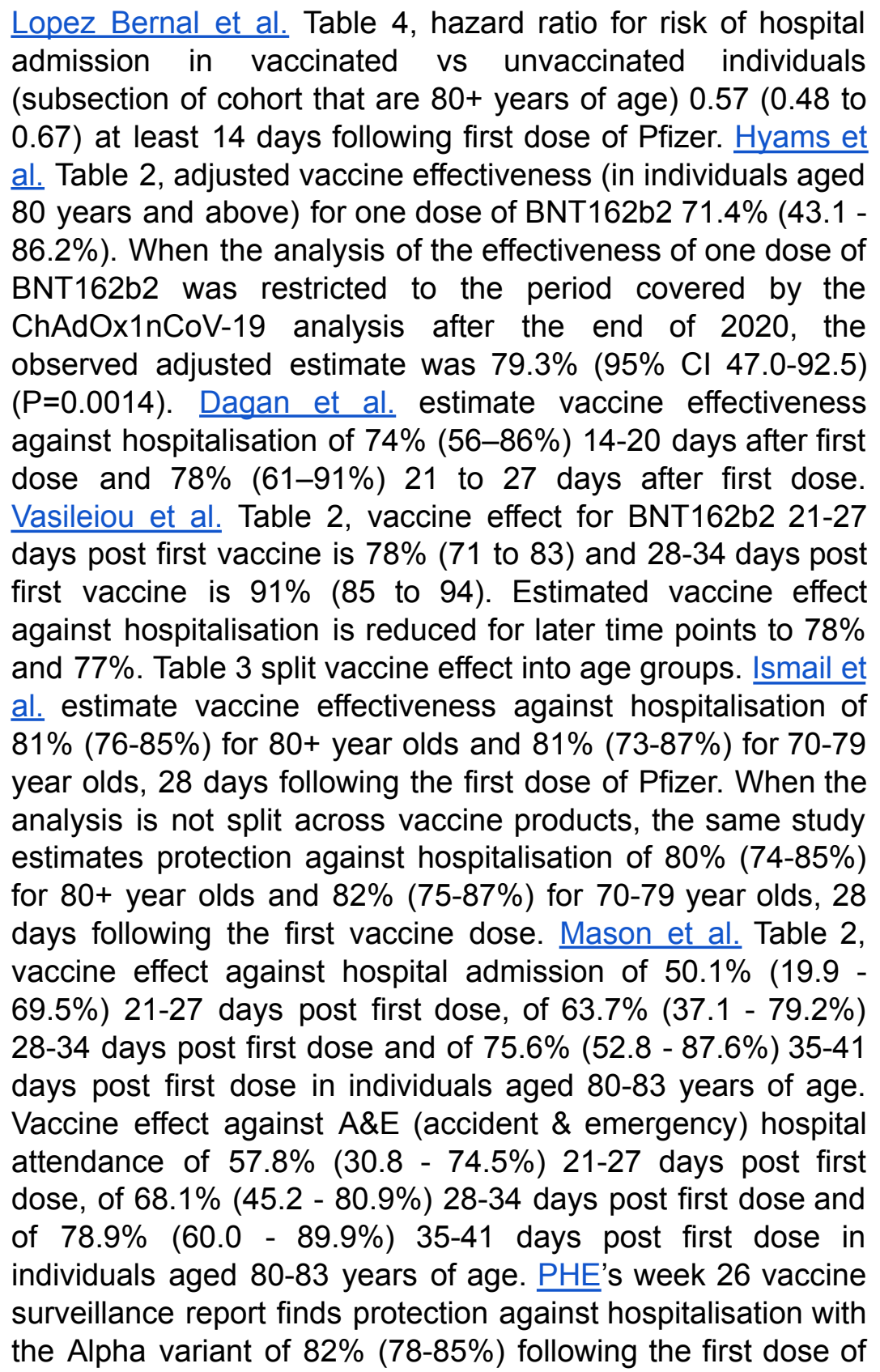 \\
\hline
\end{tabular}




\begin{tabular}{|c|c|}
\hline & $\begin{array}{l}\text { Pfizer. Stowe et al. report vaccine effectiveness against } \\
\text { hospitalisation of } 83 \%(62-93 \%) \text { following the first dose of } \\
\text { Pfizer. PHE's week } 36 \text { vaccine surveillance report estimates } \\
\text { protection against hospitalisation of } 78 \%(64-87 \%) \text { for the } \\
\text { Alpha variant at least } 28 \text { days after a first vaccine dose. } \\
\text { Andrews et al. report protection against hospitalisation for the } \\
\text { first dose of Pfizer as } 85.2 \%(81.6 \text { to } 88.1 \%) \text {, at least } 28 \text { days } \\
\text { following the first dose and up to the second dose if given. } \\
\mathbf{0 . 8 5} \text { (+28 days) }\end{array}$ \\
\hline $\begin{array}{l}\text { Overall protection against } \\
\text { mortality for Pfizer dose } 1\end{array}$ & $\begin{array}{l}\text { Dagan et al. estimate vaccine effectiveness against mortality } \\
\text { of } 72 \%(19-100 \%) 14-20 \text { days after first dose and } 84 \% \\
\text { ( } 44-100 \%) 21 \text { to } 27 \text { days after first dose. Lopez Bernal et al. B } \\
\text { (study in a care home population) estimated a hazard ratio of } \\
0.56(0.47-0.68) \text { for cases vaccinated with one dose of Pfizer } \\
\text { compared to unvaccinated cases, indicating an additional } 44 \% \\
(32-53 \%) \text { protection against death given becoming a case for } \\
\text { individuals vaccinated with one dose of Pfizer. Using the } \\
\text { aforementioned estimate of a } 44 \% \text { increase and assuming this } \\
\text { in addition to protection against disease of } 0.7 \text {, we get overall } \\
\text { protection against mortality of } 0.832 \text {. PHE's week } 26 \text { vaccine } \\
\text { surveillance report finds protection against mortality with the } \\
\text { Alpha variant of } 73 \% \text { ( } 67-77 \%) \text { and } 77 \% \text { ( } 72-81 \%) \text { for } 40-64 \\
\text { and } 65+\text { year olds respectively, following the first dose of } \\
\text { Pfizer. Andrews et al. report protection against death for the } \\
\text { first dose of Pfizer as } 73.1 \% \text { ( } 65 \text { to } 79.3 \%) \text {, at least } 28 \text { days } \\
\text { following the first dose and up to the second dose if given. } \\
0.85 \text { (+28 days) }\end{array}$ \\
\hline $\begin{array}{l}\text { Overall protection against } \\
\text { onward transmission for } \\
\text { Pfizer dose } 1\end{array}$ & $\begin{array}{l}\text { Harris et al. calculate an adjusted odds ratio of being a } \\
\text { secondary case within a household of index cases vaccinated } \\
\text { with ChAdOx1 (AstraZeneca) at least } 21 \text { days before testing } \\
\text { positive as } 0.52(0.43-0.62) \text { and index cases vaccinated with } \\
\text { BNT162b2 (Pfizer-BioNTech) at least } 21 \text { days before testing } \\
\text { positive as } 0.54(0.47-0.62) \text {. Shah et al. find that relative to the } \\
\text { period before a healthcare worker was vaccinated, the hazard } \\
\text { ratio for a household member of the vaccinated healthcare } \\
\text { worker to become infected was } 0.7(0.63-0.78) \text { for the period } \\
\text { beginning } 14 \text { days following first vaccine dose and } 0.46 \\
\text { (0.30-0.70) for the period beginning } 14 \text { days after the second } \\
\text { vaccine dose (healthcare workers were vaccinated with either } \\
\text { AstraZeneca or Pfizer). Braeye et al. (Belgium, mostly Alpha } \\
\text { variant) estimated VE against onward transmission "at } 62 \% \\
\text { (95\% Cl } 57-67 \text { ) for BNT162b2 and } 52 \% \text { ( } 95 \% \text { Cl } 33-69) \text { for } \\
\text { mRNA1273 for full vaccination. No significant effect against } \\
\text { onward transmission was found for the "viral-vector'-vaccines, } \\
\text { but credibility intervals were large." Eyre et al. report an } \\
\text { adjusted odds ratio of } 0.74 \text { ( } 0.70,0.80) \text { for the effect of a case } \\
\text { being partially vaccinated with Pfizer (dose } 1 \text { day } 1 \text { to dose } 2\end{array}$ \\
\hline
\end{tabular}


medRxiv preprint doi: https://doi.org/10.1101/2021.11.22.21266584; this version posted November 24 , 2021. The copyright holder for this preprint (which was not certified by peer review) is the author/funder, who has granted medRxiv a license to display the preprint in perpetuity.

It is made available under a CC-BY-NC-ND 4.0 International license .

\begin{tabular}{|c|c|}
\hline & $\begin{array}{l}+14 \text { days) compared to an unvaccinated case in relation to the } \\
\text { likelihood of a contact testing PCR-positive. } \\
0.47 \text { ( }+28 \text { days) }\end{array}$ \\
\hline $\begin{array}{l}\text { Overall protection against } \\
\text { infection for Pfizer dose } 2\end{array}$ & $\begin{array}{l}\text { Hall et al. Table 2, full cohort adjusted hazard ratio d2>=7 days } \\
0.15 \text { ( } 0.04-0.26) \text {. Pritchard et al., supplementary information, } \\
\text { Table } 6 \text {, adjusted odds ratio post second dose of Pfizer } 0.20 \\
(0.15,0.26) \text { for all positives. Haas et al. estimate vaccine } \\
\text { protection against SARS-CoV- } 2 \text { infection (both asymptomatic } \\
\text { and symptomatic and symptoms unknown) of } 95.3 \% \\
(94.9-95.7 \%) \text {. Shrotri et al. Table } 4 \text { adjusted hazard ratio } 0.35 \\
(0.17,0.71) \text { at } 35-48 \text { days post vaccination (first dose) for } \\
\text { protection against infection in care home residents, but no } \\
\text { estimates related to second vaccine dose. Pouwels et al. } \\
\text { report vaccine effectiveness against all PCR-confirmed } \\
\text { infections with the Alpha variant of } 78 \% \text { (68-84\%) at least } 14 \\
\text { days following the second dose of Pfizer. Sheikh et al. report } \\
\text { vaccine effectiveness against PCR-confirmed infection } \\
\text { (regardless of symptom status) of } 92 \%(90-93 \%) 14 \text { days after } \\
\text { the second dose of Pfizer. } \\
\mathbf{0 . 8 5 ~ ( + 1 4 ~ d a y s ) ~}\end{array}$ \\
\hline $\begin{array}{l}\text { Overall protection against } \\
\text { disease for Pfizer dose } 2\end{array}$ & 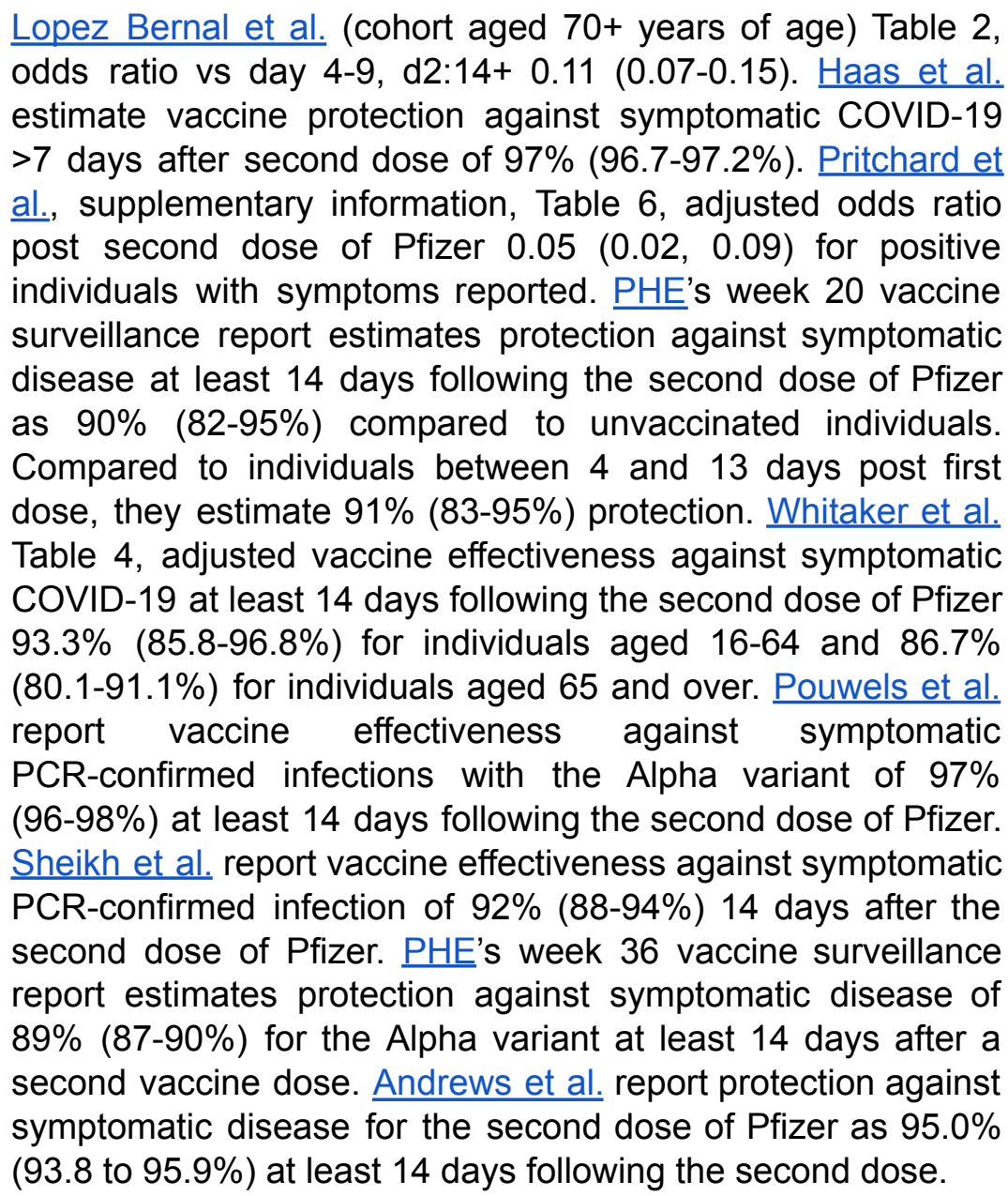 \\
\hline
\end{tabular}


medRxiv preprint doi: https://doi.org/10.1101/2021.11.22.21266584; this version posted November 24 , 2021. The copyright holder for this preprint (which was not certified by peer review) is the author/funder, who has granted medRxiv a license to display the preprint in

It is made available under a CC-BY-NC-ND 4.0 International license .

\begin{tabular}{|c|c|}
\hline & 0.9 (+14 days) \\
\hline $\begin{array}{l}\text { Overall protection against } \\
\text { hospitalisation for Pfizer } \\
\text { dose } 2\end{array}$ & 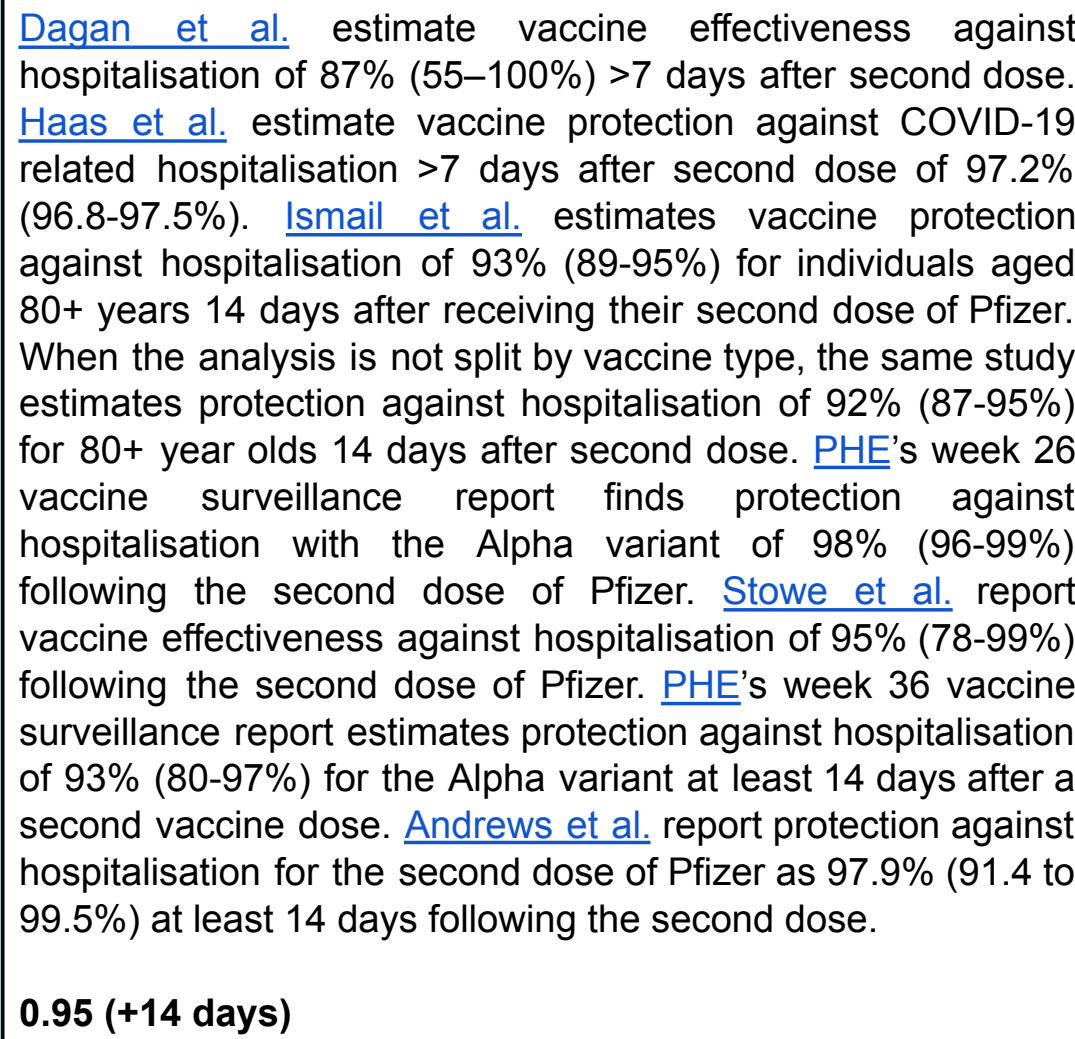 \\
\hline $\begin{array}{l}\text { Overall protection against } \\
\text { mortality for Pfizer dose } 2\end{array}$ & $\begin{array}{l}\text { Dagan et al. estimate vaccine effectiveness against mortality } \\
\text { of } 72 \%(19-100 \%) 14-20 \text { days after first dose and } 84 \% \\
(44-100 \%) 21 \text { to } 27 \text { days after first dose (no estimates for } \\
\text { second dose protection). The same study estimates protection } \\
\text { against severe disease of } 92 \% \text { ( } 75-100 \%)>7 \text { days following } \\
\text { the second dose of Pfizer. Haas et al. estimate vaccine } \\
\text { protection against death }>7 \text { days after second dose of } 96.7 \% \\
(96.0-97.3 \%) \text {. Lopez Bernal et al. B (study in a care home } \\
\text { population) estimated a hazard ratio of } 0.31 \text { ( } 0.14-0.69) \text { for } \\
\text { cases vaccinated with two doses of Pfizer compared to } \\
\text { unvaccinated cases, indicating an additional } 69 \% \text { ( } 31-86 \%) \\
\text { protection against death given becoming a case for individuals } \\
\text { vaccinated with two doses of Pfizer. Using the aforementioned } \\
\text { estimate of a } 69 \% \text { increase and assuming this in addition to } \\
\text { protection against disease of } 0.9 \text {, we get overall protection } \\
\text { against mortality of } 96.9 \% \text {. PHE's week } 26 \text { vaccine } \\
\text { surveillance report finds protection against mortality with the } \\
\text { Alpha variant of } 98 \% \text { ( } 94-99 \%) \text { for both } 40-64 \text { and } 65+\text { year } \\
\text { olds following the second dose of Pfizer. Andrews et al. report } \\
\text { protection against death for the second dose of Pfizer as } \\
96.3 \% \text { (89.9 to } 98.6 \% \text { ) at least } 14 \text { days following the second } \\
\text { dose. } \\
0.95 \text { (+14 days) }\end{array}$ \\
\hline
\end{tabular}


medRxiv preprint doi: https://doi.org/10.1101/2021.11.22.21266584; this version posted November 24,2021 . The copyright holder for this preprint (which was not certified by peer review) is the author/funder, who has granted medRxiv a license to display the preprint in

It is made available under a CC-BY-NC-ND 4.0 International license .

Overall protection against onward transmission for Pfizer dose 2
Shah et al. find that relative to the period before a healthcare worker was vaccinated, the hazard ratio for a household member of the vaccinated healthcare worker to become infected was $0.7(0.63-0.78)$ for the period beginning 14 days following first vaccine dose and $0.46(0.30-0.70)$ for the period beginning 14 days after the second vaccine dose (healthcare workers were vaccinated with either AstraZeneca or Pfizer). Braeye et al. (Belgium, mostly Alpha variant) estimated VE against onward transmission "at $62 \%(95 \% \mathrm{Cl} 57-67)$ for BNT162b2 and 52\% (95\% Cl 33-69) for mRNA1273 for full vaccination. No significant effect against onward transmission was found for the 'viral-vector'-vaccines, but credibility intervals were large." Eyre et al. report an adjusted odds ratio of $0.18(0.12,0.29)$ for the effect of a case being fully vaccinated with Pfizer (dose $2+14$ days) compared to an unvaccinated case in relation to the likelihood of a contact testing PCR-positive. 
medRxiv preprint doi: https://doi.org/10.1101/2021.11.22.21266584; this version posted November 24 , 2021. The copyright holder for this preprint (which was not certified by peer review) is the author/funder, who has granted medRxiv a license to display the preprint in

It is made available under a CC-BY-NC-ND 4.0 International license .

Table S8 - Vaccine effectiveness against B.1.617.2 Delta variant - relevant evidence and baseline model assumptions

\begin{tabular}{|c|c|}
\hline Description & Relevant evidence, assumed value shown in bold \\
\hline $\begin{array}{l}\text { Overall protection against } \\
\text { infection for AstraZeneca } \\
\text { dose } 1\end{array}$ & $\begin{array}{l}\text { Pouwels et al. report vaccine effectiveness against all } \\
\text { PCR-confirmed infections with the Delta variant of } 46 \% \\
(35-55 \%) \text { at least } 21 \text { days following the first dose of } A Z \text {. This is } \\
\text { a } 26.98 \% \text { reduction on their equivalent estimate for the Alpha } \\
\text { variant. Sheikh et al. report vaccine effectiveness against } \\
\text { PCR-confirmed infection (regardless of symptom status) of } \\
18 \%(9-25 \%) 28 \text { days after the first dose of } A Z \text {. This is a } \\
51.35 \% \text { reduction on their equivalent estimate for the Alpha } \\
\text { variant. } \\
\text { Alpha assumption } 0.7 \\
0.43=0.7 \text { * }(1-0.39) \text { (+28 days) }\end{array}$ \\
\hline $\begin{array}{l}\text { Overall protection against } \\
\text { disease for AstraZeneca } \\
\text { dose } 1\end{array}$ & 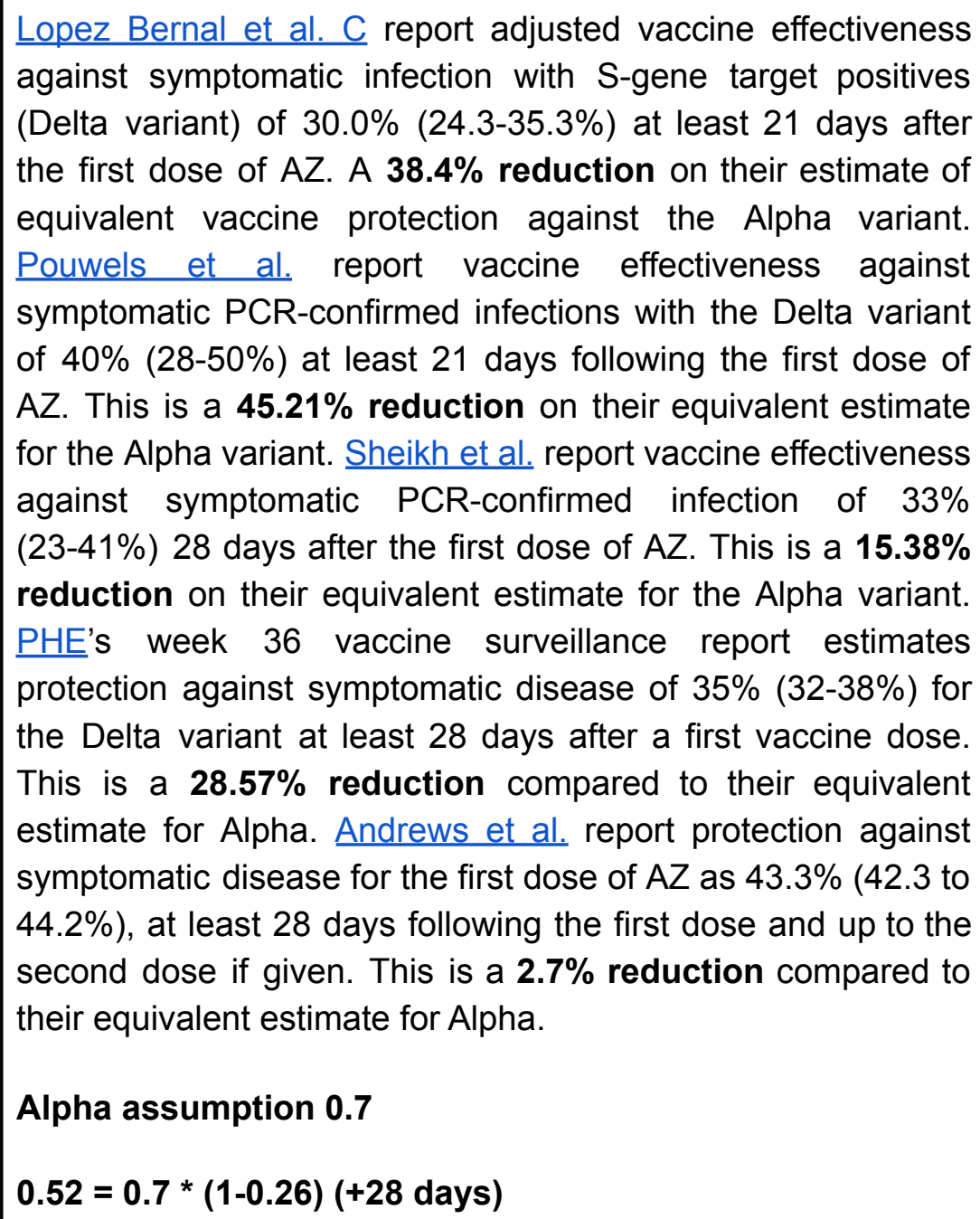 \\
\hline Overall protection against & Stowe et al. report vaccine \\
\hline
\end{tabular}


medRxiv preprint doi: https://doi.org/10.1101/2021.11.22.21266584; this version posted November 24, 2021. The copyright holder for this preprint (which was not certified by peer review) is the author/funder, who has granted medRxiv a license to display the preprint in

\begin{tabular}{|c|c|}
\hline $\begin{array}{l}\text { hospitalisation for } \\
\text { AstraZeneca dose } 1\end{array}$ & $\begin{array}{l}\text { hospitalisation of } 71 \%(51-83 \%) \text { following the first dose of } A Z \text {. } \\
\text { This is a } \mathbf{6 . 5 8 \%} \text { reduction on their equivalent estimate for the } \\
\text { Alpha variant. PHE's week } 36 \text { vaccine surveillance report } \\
\text { estimates protection against hospitalisation of } 80 \%(69-88 \%) \\
\text { for the Delta variant at least } 28 \text { days after a first vaccine dose. } \\
\text { This is a } 2.56 \% \text { increase compared to their equivalent } \\
\text { estimate for Alpha. Andrews et al. report protection against } \\
\text { hospitalisation for the first dose of AZ as } 81.4 \% \text { (78.7 to } \\
83.7 \%) \text {, at least } 28 \text { days following the first dose and up to the } \\
\text { second dose if given. This is a } \mathbf{1 . 3 \%} \text { reduction compared to } \\
\text { their equivalent estimate for Alpha. } \\
\text { Alpha assumption } \mathbf{0 . 8 5} \\
\mathbf{0 . 8 4}=\mathbf{0 . 8 5 *}(\mathbf{1 - 0 . 0 1 7 ) ~ ( + 2 8 ~ d a y s ) ~}\end{array}$ \\
\hline $\begin{array}{l}\text { Overall protection against } \\
\text { mortality for AstraZeneca } \\
\text { dose } 1\end{array}$ & $\begin{array}{l}\text { Andrews et al. report protection against death for the first dose } \\
\text { of } A Z \text { as } 88.4 \%(78.2 \text { to } 93.8 \%) \text {, at least } 28 \text { days following the } \\
\text { first dose and up to the second dose if given. This is a } 11.8 \% \\
\text { increase compared to their equivalent estimate for Alpha. } \\
\text { Alpha assumption } 0.85 \\
0.95=0.85 *(1+0.118)(+28 \text { days })\end{array}$ \\
\hline $\begin{array}{l}\text { Overall protection against } \\
\text { onward transmission for } \\
\text { AstraZeneca dose } 1\end{array}$ & $\begin{array}{l}\text { Eyre et al. report an adjusted odds ratio of } 0.98(0.90,1.06) \text { for } \\
\text { the effect of a case being partially vaccinated with } A Z \text { (dose } 1 \\
\text { day } 1 \text { to dose } 2+14 \text { days) compared to an unvaccinated case } \\
\text { in relation to the likelihood of a contact testing PCR-positive } \\
\text { (N.B. this estimate has a non-significant p-value), equivalent } \\
\text { to vaccine protection of } 2 \% \text {. Their equivalent estimate for } \\
\text { Alpha is } 0.82(0.76,0.88) \text {, therefore vaccine protection of } \\
18 \% \text {. This is a } 88.9 \% \text { overall reduction in vaccine effect from } \\
\text { Alpha to Delta. } \\
\text { Alpha assumption } \mathbf{0 . 4 7} \\
\mathbf{0 . 0 5 = 0 . 4 7 *} \mathbf{( 1 - 0 . 8 8 9 )}(\mathbf{0} \mathbf{0} \text { days) }\end{array}$ \\
\hline $\begin{array}{l}\text { Overall protection against } \\
\text { infection for AstraZeneca } \\
\text { dose } 2\end{array}$ & $\begin{array}{l}\text { Pouwels et al. report vaccine effectiveness against all } \\
\text { PCR-confirmed infections with the Delta variant of } 67 \% \\
(62-71 \%) \text { at least } 14 \text { days following the second dose of } A Z \text {. } \\
\text { This is a } 15.19 \% \text { reduction on their equivalent estimate for } \\
\text { the Alpha variant. Sheikh et al. report vaccine effectiveness } \\
\text { against PCR-confirmed infection (regardless of symptom } \\
\text { status) of } 60 \%(53-66 \%) 14 \text { days after the second dose of } A Z \text {. } \\
\text { This is a } 17.81 \% \text { reduction on their equivalent estimate for } \\
\text { the Alpha variant. }\end{array}$ \\
\hline
\end{tabular}


medRxiv preprint doi: https://doi.org/10.1101/2021.11.22.21266584; this version posted November 24 , 2021. The copyright holder for this preprint (which was not certified by peer review) is the author/funder, who has granted medRxiv a license to display the preprint in

It is made available under a CC-BY-NC-ND 4.0 International license

\begin{tabular}{|c|c|}
\hline & $\begin{array}{l}\text { Alpha assumption } 0.75 \\
0.63=0.75 *(1-0.165)(+14 \text { days })\end{array}$ \\
\hline $\begin{array}{l}\text { Overall protection against } \\
\text { disease for AstraZeneca } \\
\text { dose } 2\end{array}$ & 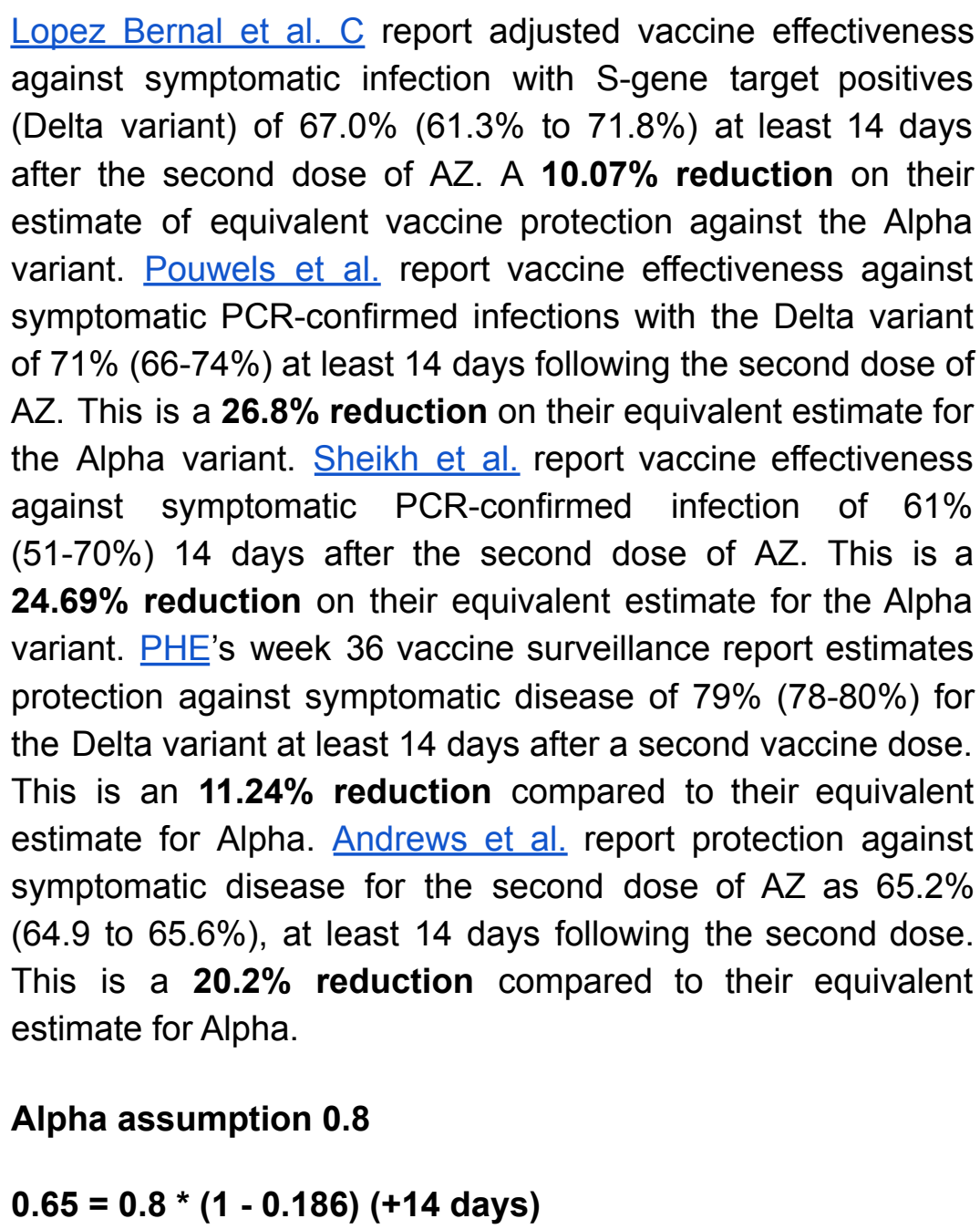 \\
\hline $\begin{array}{l}\text { Overall protection against } \\
\text { hospitalisation for } \\
\text { AstraZeneca dose } 2\end{array}$ & 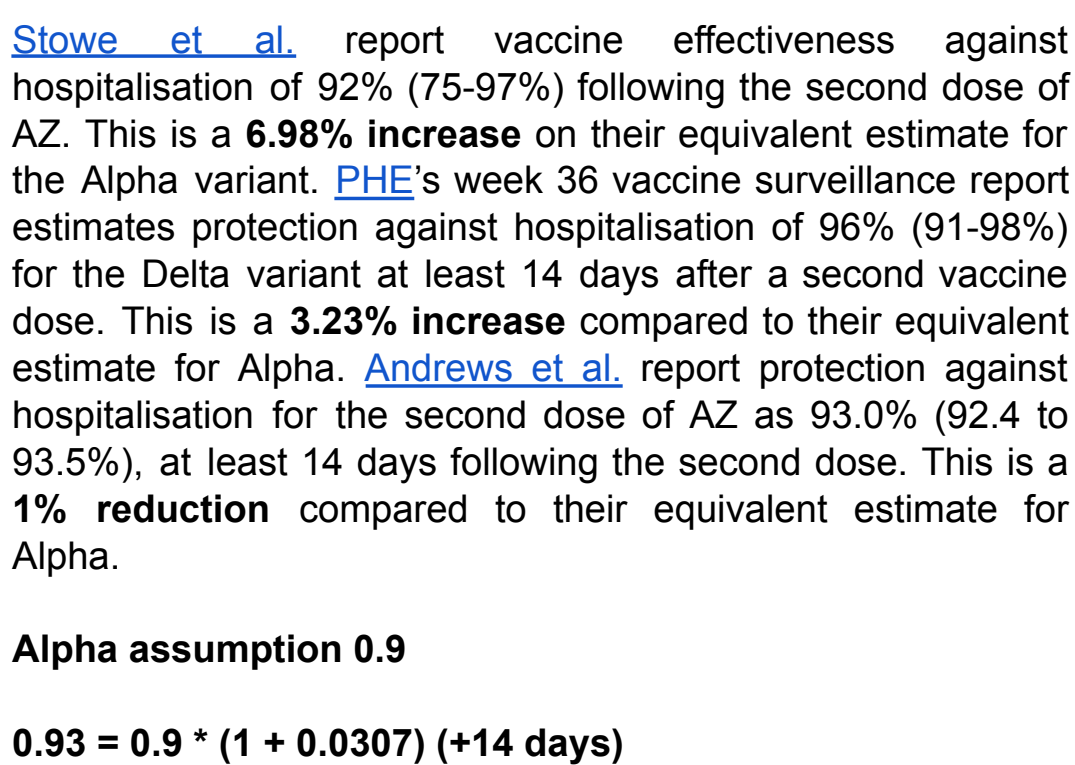 \\
\hline
\end{tabular}


medRxiv preprint doi: https://doi.org/10.1101/2021.11.22.21266584; this version posted November 24 , 2021. The copyright holder for this preprint (which was not certified by peer review) is the author/funder, who has granted medRxiv a license to display the preprint in

\begin{tabular}{|c|c|}
\hline $\begin{array}{l}\text { Overall protection against } \\
\text { mortality for AstraZeneca } \\
\text { dose } 2\end{array}$ & $\begin{array}{l}\text { Andrews et al. report protection against death for the second } \\
\text { dose of } \mathrm{AZ} \text { as } 92.7 \%(90.7 \text { to } 94.3 \%) \text {, at least } 14 \text { days } \\
\text { following the second dose. This is a } 7.3 \% \text { reduction } \\
\text { compared to their equivalent estimate for Alpha. } \\
\text { Alpha assumption } 0.95 \\
0.95 \text { (+14 days), as for dose } 1 \text { protection against mortality }\end{array}$ \\
\hline $\begin{array}{l}\text { Overall protection against } \\
\text { onward transmission for } \\
\text { AstraZeneca dose } 2\end{array}$ & $\begin{array}{l}\text { Eyre et al. report an adjusted odds ratio of } 0.64(0.57,0.72) \text { for } \\
\text { the effect of a case being fully vaccinated with } A Z \text { (dose } 2+14 \\
\text { days) compared to an unvaccinated case in relation to the } \\
\text { likelihood of a contact testing PCR-positive, equivalent to } \\
\text { vaccine protection of } 36 \% \text {. Their equivalent estimate for Alpha } \\
\text { is } 0.37(0.22,0.63) \text {, therefore vaccine protection of } 63 \% \text {. This } \\
\text { is a } 42.9 \% \text { overall reduction in vaccine effect from Alpha to } \\
\text { Delta. } \\
\text { Alpha assumption } 0.47 \\
0.27=0.47 *(1-0.429)(+14 \text { days) }\end{array}$ \\
\hline $\begin{array}{l}\text { Overall protection against } \\
\text { infection for Pfizer dose } 1\end{array}$ & 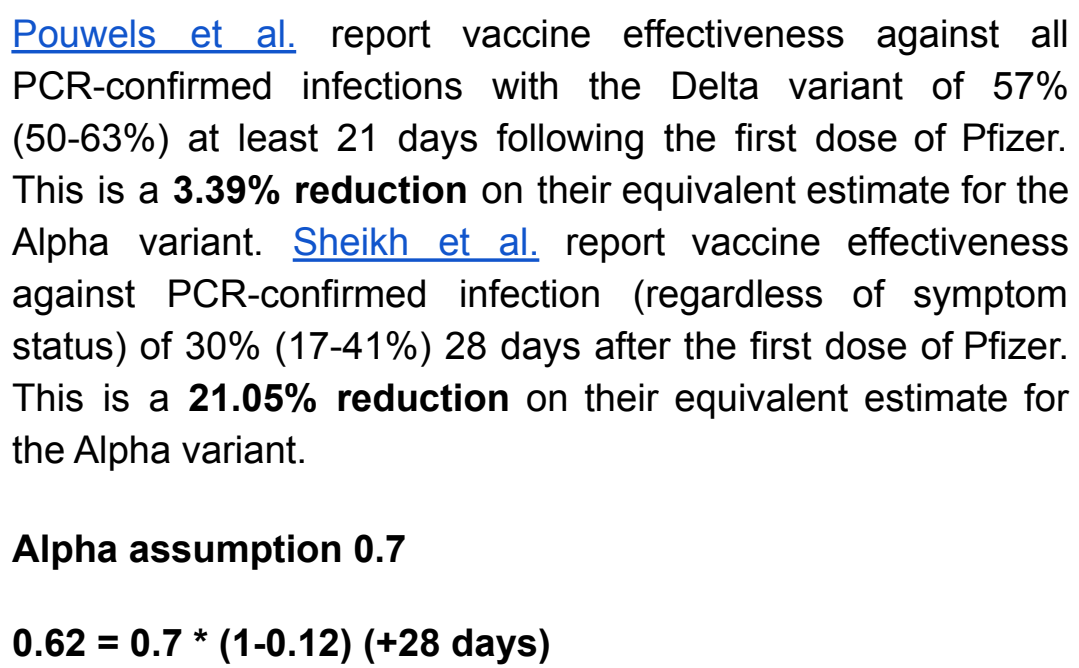 \\
\hline
\end{tabular}


medRxiv preprint doi: https://doi.org/10.1101/2021.11.22.21266584; this version posted November 24 , 2021. The copyright holder for this preprint (which was not certified by peer review) is the author/funder, who has granted medRxiv a license to display the preprint in

It is made available under a CC-BY-NC-ND 4.0 International license

Overall protection against disease for Pfizer dose 1

Overall protection against hospitalisation for Pfizer dose 1

Overall protection against mortality for Pfizer dose 1
Lopez Bernal et al. C report adjusted vaccine effectiveness against symptomatic infection with S-gene target positives (Delta variant) of $35.6 \%(22.7 \%$ to $46.4 \%)$ at least 21 days after the first dose of Pfizer. A $\mathbf{2 5 . 0 5 \%}$ reduction on their estimate of equivalent vaccine protection against the Alpha variant. Pouwels et al. report vaccine effectiveness against symptomatic PCR-confirmed infections with the Delta variant of $58 \%(51-64 \%)$ at least 21 days following the first dose of Pfizer. This is a $\mathbf{2 0 . 5 5 \%}$ reduction on their equivalent estimate for the Alpha variant. Sheikh et al. report vaccine effectiveness against symptomatic PCR-confirmed infection of $33 \%(15-47 \%) 28$ days after the first dose of Pfizer. This is a $22.22 \%$ reduction on their equivalent estimate for the Alpha variant. PHE's week 36 vaccine surveillance report estimates protection against symptomatic disease of $35 \%$ (32-38\%) for the Delta variant at least 28 days after a first vaccine dose. This is a $\mathbf{2 8 . 5 7 \%}$ reduction compared to their equivalent estimate for Alpha. Andrews et al. report protection against symptomatic disease for the first dose of Pfizer as $51.9 \%$ (51.4 to $52.4 \%$ ), at least 28 days following the first dose and up to the second dose if given. This is a $13.6 \%$ increase compared to their equivalent estimate for Alpha.

\section{Alpha assumption 0.7}

0.62 (+28 days) as for infection, otherwise would be 0.58

Stowe et al. report vaccine effectiveness against hospitalisation of $94 \%$ (46-99\%) following the first dose of Pfizer. This is a $13.25 \%$ increase on their equivalent estimate for the Alpha variant. PHE's week 36 vaccine surveillance report estimates protection against hospitalisation of $80 \%$ $(69-88 \%)$ for the Delta variant at least 28 days after a first vaccine dose. This is a $\mathbf{2 . 5 6 \%}$ increase compared to their equivalent estimate for Alpha. Andrews et al. report protection against hospitalisation for the first dose of Pfizer as $91.8 \%$ (90.4 to $93 \%$ ), at least 28 days following the first dose and up to the second dose if given. This is a $7.7 \%$ increase compared to their equivalent estimate for Alpha.

\section{Alpha assumption 0.85}

$0.92=0.85 *(1+0.078)(+28$ days $)$

Andrews et al. report protection against death for the first dose of Pfizer as $88.6 \%$ ( 77.3 to $94.3 \%$ ), at least 28 days following the first dose and up to the second dose if given. This is a $\mathbf{2 1 . 2 \%}$ increase compared to their equivalent estimate for 


\begin{tabular}{|c|c|}
\hline & $\begin{array}{l}\text { Alpha. } \\
\text { Alpha assumption } 0.85 \\
0.92 \text { (+28 days) as for hospitalisation }\end{array}$ \\
\hline $\begin{array}{l}\text { Overall protection against } \\
\text { onward transmission for } \\
\text { Pfizer dose } 1\end{array}$ & $\begin{array}{l}\text { Eyre et al. report an adjusted odds ratio of } 0.87(0.81,0.94) \text { for } \\
\text { the effect of a case being partially vaccinated with Pfizer (dose } \\
1 \text { day } 1 \text { to dose } 2+14 \text { days) compared to an unvaccinated } \\
\text { case in relation to the likelihood of a contact testing } \\
\text { PCR-positive, equivalent to vaccine protection of } 13 \% \text {. Their } \\
\text { equivalent estimate for Alpha is } 0.74(0.70,0.80) \text {, therefore } \\
\text { vaccine protection of } 26 \% \text {. This is a } 50 \% \text { overall reduction in } \\
\text { vaccine effect from Alpha to Delta. } \\
\text { Alpha assumption } \mathbf{0 . 4 7} \\
\mathbf{0 . 2 4}=\mathbf{0 . 4 7 *}(\mathbf{1}-\mathbf{0 . 5}) \mathbf{( + 2 8} \text { days) }\end{array}$ \\
\hline $\begin{array}{l}\text { Overall protection against } \\
\text { infection for Pfizer dose } 2\end{array}$ & 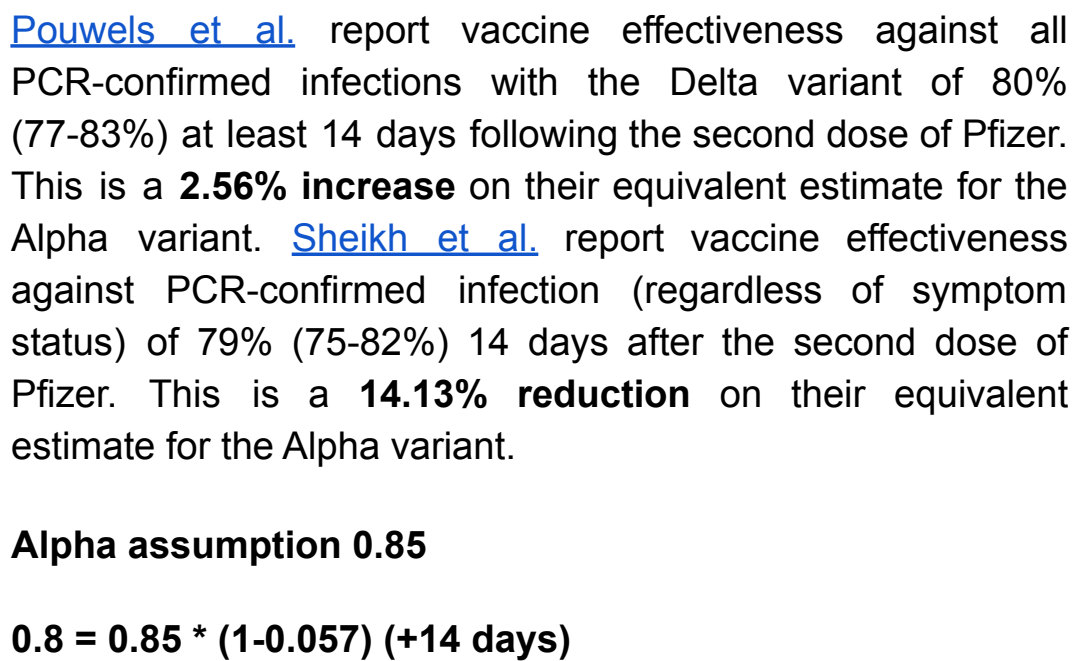 \\
\hline
\end{tabular}


medRxiv preprint doi: https://doi.org/10.1101/2021.11.22.21266584; this version posted November 24 , 2021. The copyright holder for this preprint (which was not certified by peer review) is the author/funder, who has granted medRxiv a license to display the preprint in

It is made available under a CC-BY-NC-ND 4.0 International license

Overall protection against disease for Pfizer dose 2

Overall protection against hospitalisation for Pfizer dose 2
Lopez Bernal et al. C report adjusted vaccine effectiveness against symptomatic infection with S-gene target positives (Delta variant) of $88.0 \%(85.3 \%$ to $90.1 \%)$ at least 14 days after the second dose of Pfizer. A $\mathbf{6 . 0 8 \%}$ reduction on their estimate of equivalent vaccine protection against the Alpha variant. Pouwels et al. report vaccine effectiveness against symptomatic PCR-confirmed infections with the Delta variant of $84 \%(82-86 \%)$ at least 14 days following the second dose of Pfizer. This is a $13.4 \%$ reduction on their equivalent estimate for the Alpha variant. Sheikh et al. report vaccine effectiveness against symptomatic PCR-confirmed infection of $83 \%$ $(78-87 \%) 14$ days after the second dose of Pfizer. This is a $\mathbf{9 . 7 8 \%}$ reduction on their equivalent estimate for the Alpha variant. PHE's week 36 vaccine surveillance report estimates protection against symptomatic disease of $79 \%(78-80 \%)$ for the Delta variant at least 14 days after a second vaccine dose. This is an $\mathbf{1 1 . 2 4 \%}$ reduction compared to their equivalent estimate for Alpha. Andrews et al. report protection against symptomatic disease for the second dose of Pfizer as $83.5 \%$ (83.3 to $83.6 \%$ ), at least 14 days following the second dose. This is a $12.1 \%$ reduction compared to their equivalent estimate for Alpha.

\section{Alpha assumption 0.9}

$0.81=0.9 *(1-0.105)(+14$ days $)$

Stowe et al. report vaccine effectiveness against hospitalisation of $96 \%$ (86-99\%) following the second dose of Pfizer. This is a $\mathbf{1 . 0 5 \%}$ increase on their equivalent estimate for the Alpha variant. PHE's week 36 vaccine surveillance report estimates protection against hospitalisation of $96 \%$ $(91-98 \%)$ for the Delta variant at least 14 days after a second vaccine dose. This is a $\mathbf{3 . 2 3 \%}$ increase compared to their equivalent estimate for Alpha. Andrews et al. report protection against hospitalisation for the second dose of Pfizer as $96.7 \%$ (96.3 to $97 \%$ ), at least 14 days following the second dose. This is a $1.2 \%$ reduction compared to their equivalent estimate for Alpha.

Alpha assumption 0.95

$0.96=0.95 *(1+0.0103)(+14$ days $)$ 
medRxiv preprint doi: https://doi.org/10.1101/2021.11.22.21266584; this version posted November 24 , 2021. The copyright holder for this preprint (which was not certified by peer review) is the author/funder, who has granted medRxiv a license to display the preprint in

\begin{tabular}{|c|c|}
\hline $\begin{array}{l}\text { Overall protection against } \\
\text { mortality for Pfizer dose } 2\end{array}$ & $\begin{array}{l}\text { Andrews et al. report protection against death for the second } \\
\text { dose of Pfizer as } 95.2 \%(93.7 \text { to } 96.4 \%) \text {, at least } 14 \text { days } \\
\text { following the second dose. This is a } \mathbf{1 . 1 \% \text { reduction }} \\
\text { compared to their equivalent estimate for Alpha. } \\
\text { Alpha assumption } 0.95 \\
\mathbf{0 . 9 6} \text { (+14 days) as for hospitalisation }\end{array}$ \\
\hline $\begin{array}{l}\text { Overall protection against } \\
\text { onward transmission for } \\
\text { Pfizer dose } 2\end{array}$ & $\begin{array}{l}\text { Eyre et al. report an adjusted odds ratio of } 0.35(0.26,0.48) \text { for } \\
\text { the effect of a case being fully vaccinated with Pfizer (dose } 2 \\
+14 \text { days) compared to an unvaccinated case in relation to the } \\
\text { likelihood of a contact testing PCR-positive, equivalent to } \\
\text { vaccine protection of } 65 \% \text {. Their equivalent estimate for Alpha } \\
\text { is } 0.18(0.12,0.29) \text {, therefore vaccine protection of } 82 \% \text {. This } \\
\text { is a } 20.7 \% \text { overall reduction in vaccine effect from Alpha to } \\
\text { Delta. } \\
\text { Alpha assumption } 0.47 \\
0.37=0.47 *(1-0.207) \text { (+14 days) }\end{array}$ \\
\hline
\end{tabular}

\section{Working group authors and acknowledgements}

\section{CMMID COVID-19 Working Group}

The following authors were part of the Centre for Mathematical Modelling of Infectious Disease COVID-19 working group. Each contributed in processing, cleaning and interpretation of data, interpreted findings, contributed to the manuscript, and approved the work for publication: James D Munday, Rachel Lowe, Gwenan M Knight, Quentin J Leclerc, Damien C Tully, David Hodgson, Rachael Pung, Joel Hellewell, Mihaly Koltai, David Simons, Kaja Abbas, Adam J Kucharski, Simon R Procter, Frank G Sandmann, Carl A B Pearson, Kiesha Prem, Alicia Showering, Sophie R Meakin, Kathleen O'Reilly, Ciara V McCarthy, Matthew Quaife, Kerry LM Wong, Yalda Jafari, Arminder K Deol, Rein M G J Houben, Charlie Diamond, Thibaut Jombart, C Julian Villabona-Arenas, William Waites, Rosalind M Eggo, Akira Endo, Hamish P Gibbs, Petra Klepac, Jack Williams, Billy J Quilty, Oliver Brady, Jon C Emery, Katherine E Atkins, Lloyd A C Chapman, Katharine Sherratt, Sam Abbott, Nikos I Bosse, Paul Mee, Sebastian Funk, Jiayao Lei, Yang Liu, Stefan Flasche, James W Rudge, Fiona Yueqian Sun, Graham Medley, Timothy W Russell, Amy Gimma, Stéphane Hué, Christopher I Jarvis, Emilie Finch and Samuel Clifford.

CMMID COVID-19 Working Group funding statements

PK (Royal Society: RPIEAl180004, European Commission: 101003688), TJ (Global Challenges Research Fund: ES/P010873/1, UK Public Health Rapid Support Team, NIHR: Health Protection Research Unit for Modelling Methodology HPRU-2012-10096, UK MRC: MC_PC_19065), AG (European Commission: 101003688), SFlasche (Wellcome Trust: 
medRxiv preprint doi: https://doi.org/10.1101/2021.11.22.21266584; this version posted November 24 , 2021. The copyright holder for this preprint (which was not certified by peer review) is the author/funder, who has granted medRxiv a license to display the preprint in

208812/Z/17/Z), RL (Royal Society: Dorothy Hodgkin Fellowship), DH (NIHR: 1R01Al141534-01A1), AJK (Wellcome Trust: 206250/Z/17/Z, NIHR: NIHR200908), HPG (EDCTP2: RIA2020EF-2983-CSIGN, UK DHSC/UK Aid/NIHR: PR-OD-1017-20001), SFunk (Wellcome Trust: 210758/Z/18/Z), GMK (UK MRC: MR/P014658/1), WW (MRC: MR/V027956/1), RME (HDR UK: MR/S003975/1, UK MRC: MC_PC_19065, NIHR: NIHR200908), MK (Wellcome Trust: 221303/Z/20/Z), LACC (NIHR: NIHR200908), YL (B\&MGF: INV-003174, NIHR: 16/137/109, European Commission: 101003688, UK MRC: MC_PC_19065), KA (BMGF: INV-016832; OPP1157270), KO'R (B\&MGF: OPP1191821), KEA (ERC: SG 757688), FYS (NIHR: 16/137/109), FGS (NIHR: NIHR200929), RP (Singapore Ministry of Health), PM CADDE (MR/S0195/1 \& FAPESP 18/14389-0), SC (Wellcome Trust: 208812/Z/17/Z, UK MRC: MC_PC_19065), SA (Wellcome Trust: 210758/Z/18/Z), CIJ (Global Challenges Research Fund: ES/P010873/1), CVM (NIHR: NIHR200929), NIB (HPRU: NIHR200908), SRP (B\&MGF: INV-016832), KLM (European Commission: 101003688), JH (Wellcome Trust: 210758/Z/18/Z), YJ (UKRI: MR/V028456/1), MQ (ERC Starting Grant: \#757699, B\&MGF: INV-001754), OJB (Wellcome Trust: 206471/Z/17/Z), JDM (Wellcome Trust: 210758/Z/18/Z), TWR (Wellcome Trust: 206250/Z/17/Z), KP (B\&MGF: INV-003174, European Commission: 101003688), BJQ (NIHR: 16/137/109, NIHR: 16/136/46, B\&MGF: OPP1139859), SRM (Wellcome Trust: 210758/Z/18/Z), GFM (B\&MGF: NTD Modelling Consortium OPP1184344), EF (MRC: MR/N013638/1), CJVA (ERC: SG 757688), CABP (B\&MGF: NTD Modelling Consortium OPP1184344, FCDO/Wellcome Trust: Epidemic Preparedness Coronavirus research programme 221303/Z/20/Z), AE (Nakajima Foundation), JCE (ERC Starting Grant: \#757699), QJL (UK MRC: LID DTP MR/N013638/1), RMGJH (ERC Starting Grant: \#757699), CD (NIHR: 16/137/109), JYL (B\&MGF: INV-003174), KS (Wellcome Trust: 210758/Z/18/Z), DS (BBSRC LIDP: BB/M009513/1), JWR (DTRA: HDTRA1-18-1-0051). 
medRxiv preprint doi: https://doi.org/10.1101/2021.11.22.21266584; this version posted November 24 , 2021. The copyright holder for this preprint (which was not certified by peer review) is the author/funder, who has granted medRxiv a license to display the preprint in It is made available under a CC-BY-NC-ND 4.0 International license .

\section{References}

1. Ritchie H, Mathieu E, Rodés-Guirao L, Appel C, Giattino C, Ortiz-Ospina E, et al. Coronavirus Pandemic (COVID-19). Our World in Data [Internet]. 2020 Mar 5 [cited 2021 Oct 18]; Available from: https://ourworldindata.org/coronavirus

2. Daily summary [Internet]. [cited 2021 Oct 18]. Available from: https://https://coronavirus.data.gov.uk/

3. Tracking SARS-CoV-2 variants [Internet]. [cited 2021 Oct 18]. Available from: https://www.who.int/activities/tracking-SARS-CoV-2-variants

4. Website [Internet]. Available from:

https://www.instituteforgovernment.org.uk/charts/uk-government-coronavirus-lockdowns

5. Joint Committee on Vaccination and Immunisation: advice on priority groups for COVID-19 vaccination, 30 December 2020 [Internet]. [cited 2021 Oct 18]. Available from:

https://www.gov.uk/government/publications/priority-groups-for-coronavirus-covid-19-vac cination-advice-from-the-jcvi-30-december-2020/joint-committee-on-vaccination-and-im munisation-advice-on-priority-groups-for-covid-19-vaccination-30-december-2020

6. Department of Health and Social Care. All young people aged 16 and 17 in England to be offered vaccine by next week [Internet]. GOV.UK. 2021 [cited 2021 Oct 18]. Available from:

https://www.gov.uk/government/news/all-young-people-aged-16-and-17-in-england-to-b e-offered-vaccine-by-next-week

7. COVID-19 vaccination programme for children and young people: guidance for schools [Internet]. [cited 2021 Oct 22]. Available from:

https://www.gov.uk/government/publications/covid-19-vaccination-resources-for-schools/ covid-19-vaccination-programme-for-children-and-young-people-guidance-for-schools

8. UK Health Security Agency. JCVI issues advice on COVID-19 booster vaccines for those aged 40 to 49 and second doses for 16 to 17 year olds [Internet]. GOV.UK. 2021 [cited 2021 Nov 18]. Available from:

https://www.gov.uk/government/news/jcvi-issues-advice-on-covid-19-booster-vaccines-f or-those-aged-40-to-49-and-second-doses-for-16-to-17-year-olds

9. Public Health England. JCVI issues advice on third dose vaccination for severely immunosuppressed [Internet]. GOV.UK. 2021 [cited 2021 Oct 18]. Available from: https://www.gov.uk/government/news/jcvi-issues-advice-on-third-dose-vaccination-for-se verely-immunosuppressed

10. Iacobucci G. Covid-19: Government is "wilfully negligent" in not acting on rising numbers, says BMA. BMJ [Internet]. 2021 Oct 21;375:n2578. Available from: http://dx.doi.org/10.1136/bmj.n2578

11. UK Health Security Agency. COVID-19 vaccine weekly surveillance reports (weeks 39 to 42) [Internet]. GOV.UK; 2021 [cited 2021 Oct 22]. Available from:

https://www.gov.uk/government/publications/covid-19-vaccine-weekly-surveillance-repor ts 
medRxiv preprint doi: https://doi.org/10.1101/2021.11.22.21266584; this version posted November 24 , 2021. The copyright holder for this preprint (which was not certified by peer review) is the author/funder, who has granted medRxiv a license to display the preprint in It is made available under a CC-BY-NC-ND 4.0 International license .

12. Andrews N, Tessier E, Stowe J, Gower C, Kirsebom F, Simmons R, et al. Vaccine effectiveness and duration of protection of Comirnaty, Vaxzevria and Spikevax against mild and severe COVID-19 in the UK. medRxiv [Internet]. 2021 Oct 6 [cited 2021 Nov 4];2021.09.15.21263583. Available from:

https://www.medrxiv.org/content/10.1101/2021.09.15.21263583v2.abstract

13. Willis KSA. Coronavirus (COVID-19) Infection Survey: England [Internet]. Office for National Statistics; 2021 [cited 2021 Oct 18]. Available from:

https://www.localhost/peoplepopulationandcommunity/healthandsocialcare/conditionsan ddiseases/datasets/coronaviruscovid19infectionsurveydata

14. Interim statement on COVID-19 vaccine booster doses [Internet]. [cited 2021 Oct 22]. Available from:

https://www.who.int/news/item/10-08-2021-interim-statement-on-covid-19-vaccine-boost er-doses

15. Teslya A, Pham TM, Godijk NG, Kretzschmar ME, Bootsma MCJ, Rozhnova G. Impact of self-imposed prevention measures and short-term government-imposed social distancing on mitigating and delaying a COVID-19 epidemic: A modelling study. PLoS Med [Internet]. 2020 Jul 21 [cited 2021 Nov 19];17(7):e1003166. Available from: https://journals.plos.org/plosmedicine/article/file?id=10.1371/journal.pmed.1003166\&typ e=printable

16. Weitz JS, Park SW, Eksin C, Dushoff J. Awareness-driven behavior changes can shift the shape of epidemics away from peaks and toward plateaus, shoulders, and oscillations. Proc Natl Acad Sci U S A [Internet]. 2020 Dec 22 [cited 2021 Nov 19];117(51):32764-71. Available from:

https://www.pnas.org/content/117/51/32764.abstract

17. Davies NG, Barnard RC, Jarvis CI, Russell TW, Semple MG, Jit M, et al. Association of tiered restrictions and a second lockdown with COVID-19 deaths and hospital admissions in England: a modelling study [Internet]. Vol. 21, The Lancet Infectious Diseases. 2021. p. 482-92. Available from: http://dx.doi.org/10.1016/s1473-3099(20)30984-1

18. Davies NG, Abbott S, Barnard RC, Jarvis Cl, Kucharski AJ, Munday JD, et al. Estimated transmissibility and impact of SARS-CoV-2 lineage B.1.1.7 in England. Science [Internet]. 2021 Apr 9;372(6538). Available from: http://dx.doi.org/10.1126/science.abg3055

19. Scientific Advisory Group for Emergencies. LSHTM: Updated roadmap assessment prior to delayed Step 4, 7 July 2021 [Internet]. GOV.UK; 2021 [cited 2021 Oct 18].

Available from:

https://www.gov.uk/government/publications/lshtm-updated-roadmap-assessment-prior-t o-delayed-step-4-7-july-2021

20. COVID-19 hub [Internet]. [cited 2021 Oct 18]. Available from: https://www.ukbiobank.ac.uk/learn-more-about-uk-biobank/covid-19-hub

21. Real-time Assessment of Community Transmission findings [Internet]. [cited 2020 Nov 2]. Available from:

https://www.imperial.ac.uk/medicine/research-and-impact/groups/react-study/real-time-a 
medRxiv preprint doi: https://doi.org/10.1101/2021.11.22.21266584; this version posted November 24 , 2021. The copyright holder for this preprint (which was not certified by peer review) is the author/funder, who has granted medRxiv a license to display the preprint in It is made available under a CC-BY-NC-ND 4.0 International license .

ssessment-of-community-transmission-findings/

22. Hill RYA. Coronavirus (COVID-19) Infection Survey, antibody and vaccination data, UK [Internet]. Office for National Statistics; 2021 [cited 2021 Oct 18]. Available from: https://www.localhost/peoplepopulationandcommunity/healthandsocialcare/conditionsan ddiseases/datasets/coronaviruscovid19antibodydatafortheuk

23. Davies NG, Klepac P, Liu Y, Prem K, Jit M, CMMID COVID-19 working group, et al. Age-dependent effects in the transmission and control of COVID-19 epidemics. medRxiv [Internet]. 2020 Mar 27 [cited 2020 Mar 29];2020.03.24.20043018. Available from: https://www.medrxiv.org/content/10.1101/2020.03.24.20043018v1.abstract

24. Levin AT, Hanage WP, Owusu-Boaitey N, Cochran KB, Walsh SP, Meyerowitz-Katz G. Assessing the Age Specificity of Infection Fatality Rates for COVID-19: Systematic Review, Meta-Analysis, and Public Policy Implications. medRxiv [Internet]. 2020 Oct 31 [cited 2020 Nov 6];2020.07.23.20160895. Available from:

https://www.medrxiv.org/content/10.1101/2020.07.23.20160895v7.abstract

25. Public Health England. Investigation of SARS-CoV-2 variants of concern: technical briefings [Internet]. GOV.UK; 2020 [cited 2021 Oct 18]. Available from:

https://www.gov.uk/government/publications/investigation-of-novel-sars-cov-2-variant-va riant-of-concern-20201201

26. Google. COVID-19 Community Mobility Reports [Internet]. [cited 2021 Oct 18]. Available from: https://www.google.com/covid19/mobility/

27. Attendance in education and early years settings during the coronavirus (COVID-19) pandemic [Internet]. [cited 2021 Oct 18]. Available from:

https://explore-education-statistics.service.gov.uk/find-statistics/attendance-in-education -and-early-years-settings-during-the-coronavirus-covid-19-outbreak

28. Braak CJFT. A Markov Chain Monte Carlo version of the genetic algorithm Differential Evolution: easy Bayesian computing for real parameter spaces. Stat Comput [Internet]. 2006 Sep 1;16(3):239-49. Available from: https://doi.org/10.1007/s11222-006-8769-1

29. Endo A, van Leeuwen E, Baguelin M. Introduction to particle Markov-chain Monte Carlo for disease dynamics modellers. Epidemics [Internet]. 2019 Dec;29:100363. Available from: http://dx.doi.org/10.1016/j.epidem.2019.100363

30. Hyndman RJ, Khandakar Y. Automatic Time Series Forecasting: The forecast Package for R. J Stat Softw [Internet]. 2008 Jul 29 [cited 2021 Nov 19];27:1-22. Available from: https://www.jstatsoft.org/index.php/jss/article/view/v027i03

31. Website [Internet]. Available from: https://doi.org/10.1016/S0140-6736(21)01694-9

32. Mills MC, Ruettenauer T. The impact of mandatory COVID-19 certificates on vaccine uptake: Synthetic Control Modelling of Six Countries [Internet]. bioRxiv. 2021. Available from: http://medrxiv.org/lookup/doi/10.1101/2021.10.08.21264718

33. Jarvis C, Gimma A, Wong K, Edmunds J, CMMID COVID-19 Working Group. Social contacts in the UK from the CoMix social contact survey: Report for survey week 80 [Internet]. [cited 2021 Nov 19]. Available from:

https://cmmid.github.io/topics/covid19/reports/comix/Comix\%20Weekly\%20Report\%208 
medRxiv preprint doi: https://doi.org/10.1101/2021.11.22.21266584; this version posted November 24 , 2021. The copyright holder for this preprint (which was not certified by peer review) is the author/funder, who has granted medRxiv a license to display the preprint in

0.pdf

34. Leech G, Rogers-Smith C, Sandbrink JB, Snodin B, Zinkov R, Rader B, et al. Mass mask-wearing notably reduces COVID-19 transmission [Internet]. bioRxiv. medRxiv; 2021. Available from: http://medrxiv.org/lookup/doi/10.1101/2021.06.16.21258817

35. Abaluck J, Kwong LH, Styczynski A, Haque A, Kabir MA, Bates-Jefferys E, et al. The Impact of Community Masking on COVID-19: A Cluster-Randomized Trial in Bangladesh [Internet]. 2021 [cited 2021 Nov 19]. Available from:

https://www.poverty-action.org/publication/impact-community-masking-covid-19-cluster-r andomized-trial-bangladesh

36. COVID-19 hub [Internet]. [cited 2021 Nov 18]. Available from: https://www.ukbiobank.ac.uk/learn-more-about-uk-biobank/covid-19-hub

37. Real-time Assessment of Community Transmission findings [Internet]. [cited 2021 Nov 18]. Available from:

http://www.imperial.ac.uk/medicine/research-and-impact/groups/react-study/real-time-as sessment-of-community-transmission-findings/

38. Scientific Advisory Group for Emergencies. LSHTM: Interim roadmap assessment prior to steps 3 and 4, 5 May 2021 [Internet]. GOV.UK; 2021 [cited 2021 Nov 19].

Available from:

https://www.gov.uk/government/publications/lshtm-interim-roadmap-assessment-prior-to -steps-3-and-4-5-may-2021

39. Lauer SA, Grantz KH, Bi Q, Jones FK, Zheng Q, Meredith HR, et al. The Incubation Period of Coronavirus Disease 2019 (COVID-19) From Publicly Reported Confirmed Cases: Estimation and Application. Ann Intern Med [Internet]. 2020 May 5;172(9):577-82. Available from: http://dx.doi.org/10.7326/M20-0504

40. Ferretti L, Ledda A, Wymant C, Zhao L, Ledda V, Abeler- Dorner L, et al. The timing of COVID-19 transmission. Epidemiology. medRxiv; 2020.

41. Li Q, Guan X, Wu P, Wang X, Zhou L, Tong Y, et al. Early Transmission Dynamics in Wuhan, China, of Novel Coronavirus-Infected Pneumonia. N Engl J Med [Internet]. 2020 Mar 26;382(13):1199-207. Available from: http://dx.doi.org/10.1056/NEJMoa2001316

42. Nishiura $\mathrm{H}$, Linton NM, Akhmetzhanov AR. Serial interval of novel coronavirus (COVID-19) infections. Int J Infect Dis [Internet]. 2020 Apr;93:284-6. Available from: http://dx.doi.org/10.1016/j.jijd.2020.02.060

43. Bi Q, Wu Y, Mei S, Ye C, Zou X, Zhang Z, et al. Epidemiology and transmission of COVID-19 in 391 cases and 1286 of their close contacts in Shenzhen, China: a retrospective cohort study. Lancet Infect Dis [Internet]. 2020 Aug;20(8):911-9. Available from: https://linkinghub.elsevier.com/retrieve/pii/S1473309920302875

44. Davies NG, Kucharski AJ, Eggo RM, Gimma A, Edmunds WJ, Centre for the Mathematical Modelling of Infectious Diseases COVID-19 working group. Effects of non-pharmaceutical interventions on COVID-19 cases, deaths, and demand for hospital services in the UK: a modelling study. Lancet Public Health [Internet]. 2020 Jul;5(7):e375-85. Available from: http://dx.doi.org/10.1016/S2468-2667(20)30133-X

45. Mossong J, Hens N, Jit M, Beutels P, Auranen K, Mikolajczyk R, et al. Social contacts 
medRxiv preprint doi: https://doi.org/10.1101/2021.11.22.21266584; this version posted November 24,2021 . The copyright holder for this preprint (which was not certified by peer review) is the author/funder, who has granted medRxiv a license to display the preprint in It is made available under a CC-BY-NC-ND 4.0 International license.

and mixing patterns relevant to the spread of infectious diseases. PLoS Med [Internet]. 2008 Mar 25;5(3):e74. Available from: http://dx.doi.org/10.1371/journal.pmed.0050074

46. Population estimates for the UK, England and Wales, Scotland and Northern Ireland Office for National Statistics [Internet]. [cited 2020 Mar 29]. Available from:

https://www.ons.gov.uk/peoplepopulationandcommunity/populationandmigration/populati onestimates/bulletins/annualmidyearpopulationestimates/mid2018

47. Docherty AB, Harrison EM, Green CA, Hardwick HE, Pius R, Norman L, et al. Features of 20133 UK patients in hospital with covid-19 using the ISARIC WHO Clinical Characterisation Protocol: prospective observational cohort study. BMJ [Internet]. 2020 May 22 [cited 2020 Nov 6];369. Available from:

https://www.bmj.com/content/369/bmj.m1985.abstract 